\title{
The Integration of Geomorphic Design into West Virginia Surface Mine Reclamation
}

\author{
Alison E. Sears \\ West Virginia University
}

Follow this and additional works at: https://researchrepository.wvu.edu/etd

\section{Recommended Citation}

Sears, Alison E., "The Integration of Geomorphic Design into West Virginia Surface Mine Reclamation" (2012). Graduate Theses, Dissertations, and Problem Reports. 4916.

https://researchrepository.wvu.edu/etd/4916

This Thesis is protected by copyright and/or related rights. It has been brought to you by the The Research Repository @ WVU with permission from the rights-holder(s). You are free to use this Thesis in any way that is permitted by the copyright and related rights legislation that applies to your use. For other uses you must obtain permission from the rights-holder(s) directly, unless additional rights are indicated by a Creative Commons license in the record and/ or on the work itself. This Thesis has been accepted for inclusion in WVU Graduate Theses, Dissertations, and Problem Reports collection by an authorized administrator of The Research Repository @ WVU. For more information, please contact researchrepository@mail.wvu.edu. 
The Integration of Geomorphic Design into West Virginia Surface Mine Reclamation

\author{
Alison E. Sears \\ Thesis submitted to \\ Benjamin M. Statler College of Engineering and Mineral Resources \\ At West Virginia University \\ In partial fulfillment of the requirements \\ For the degree of \\ Master of Science \\ In \\ Mining Engineering
}

Christopher Bise, Ph.D., Chairman

John Quaranta, Ph.D., Co-Chairman

Leslie Hopkinson, Ph.D.

Brijes Mishra, Ph.D.

Department of Mining Engineering

Department of Civil Engineering

Morgantown, West Virginia

2012

Keywords: Surface Mining, Geomorphic Design,

Landform Design, Surface Mine Reclamation 


\section{Abstract \\ The Integration of Geomorphic Design into West Virginia Surface Mine Reclamation Alison E. Sears}

Approximately $40 \%$ of operating mines in West Virginia are surface mines, producing around 50 million tons of coal each year. Federal regulations that have been designed to control environmental impacts associated with surface mining are becoming increasingly stringent. The West Virginia Department of Environmental Protection (WVDEP) Division of Mining and Reclamation and the United States Environmental Protection Agency (EPA) recently have delayed or temporarily suspended surface mining permits because of the implementation of more rigorous standards relating to reclamation and post-mining land use. As the demand for energy continues to increase, there is a need to find an alternative to the typical surface mine reclamation techniques used today in Appalachia.

The short-term outcome of this research was to assess the feasibility of coal companies to implement geomorphic design into surface mine reclamation in Appalachia. Many other considerations were studied throughout the duration of this project. Laws and regulations were also evaluated to determine where geomorphic design may be applied in Appalachian surface mining. With regulations becoming more stringent and changing frequently, implementing geomorphic ideas into the steep terrain of Appalachia while adhering to current regulations is a challenge. However, this is the first step in creating a successful geomorphic reclamation design.

The long-term outcome of this research was to incorporate Carlson ${ }^{\circledR}$ 's Natural Regrade ${ }^{\circledR}$ with GeoFluv ${ }^{\mathrm{TM}}$ software to create a geomorphic design for a sample surface mine in southern West Virginia. While this innovative reclamation design approach has been used with success in semi-arid regions of the United States, as well as throughout the world, the approach has not been utilized in West Virginia. One main purpose of this project was to analyze the effectiveness of geomorphic reclamation on surface mines in West Virginia as well as a comparison of the features of the completed geomorphic valley-fill design contrasted to an approximate original contour variance valley-fill design. By creating a geomorphic reclamation design for a site in West Virginia, data could be collected and compared directly to traditional designs in order to determine and assess advantages and disadvantages of implementing this innovative surface reclamation technique in Appalachia.

A safety analysis was also performed to compare both a traditional valley-fill design and the completed geomorphic valley-fill design so that any significant safety benefits or disadvantages could be assessed. Stream analysis, including the length of original streams, length of created streams, stream classification, and stream type, was performed to identify complete drainage systems. All of the numerous aspects that were analyzed between the traditional and geomorphic valley-fill designs, in return, yielded an accurate analysis of the benefits and/or disadvantages of the nontraditional reclamation approach as well as the ability to implement this geomorphic reclamation design method in West Virginia. Following the comparison, it was found that the Approximate Original Contour (AOC) variance valley-fill design was intended to ensure slope stability, control drainage, complement the drainage pattern of the surrounding terrain, and prevent stream sedimentation. The design consisted of:

- slope shapes exhibiting uniform benches

- planar slopes having unvarying contours

- drainage ditches located along the perimeter and/or center of the fill 
However, the traditional, planar reclamation method can be improved to appear more natural and decrease the drawbacks associated with it.

Features of the resulting Natural Regrade ${ }^{\circledR}$ design include:

- long-term stability due to dynamic equilibrium

- $\quad$ suggested reduction in maintenance due to stability

- projected reduced cost due to strategic placement of fill material

- more aesthetically pleasing valley fill due to a diverse natural habitat with ridges and valleys

These landform designs add variability and aid in establishing a site with a long-term hydrologic balance. The geomorphic landform reclamation approach has potential to extend beyond current industry practices and will improve environmental impacts, flood control, water quality, and human safety. 


\section{Acknowledgements}

The author would like to thank all of the people who committed their time and effort to the success of this research and her success in return. The people that provided particular support and guidance include Dr. Christopher Bise and Dr. John Quaranta for serving as my advisors, Dr. Leslie Hopkinson for serving as a committee member and her continued help and guidance, Dr. Brijes Mishra for serving as a committee member, and Dan Hause for his continued expertise and assistance with Carlson ${ }^{\circledR}$ Natural Regrade ${ }^{\circledR}$. Without the knowledge and supervision of these individuals, this research would not have been successful.

In addition to her colleagues, the author would like to extend her gratitude to the Department of Mining Engineering for their support and the Coal and Energy Research Bureau for the funding of the research discussed throughout this dissertation.

The author would also like to thank her family, fiancé, and friends for their continued support and confidence in my education endeavors. Above all, she would like to my parents who instilled in her an importance of higher education since an early age. This thesis is dedicated to her late Daddy-o, Casey Allen Sears, who will forever be her encouragement and strength throughout her life. 


\section{Table of Contents}

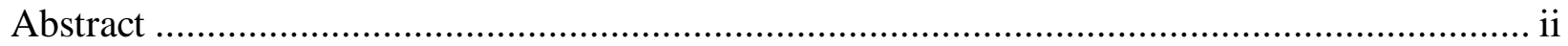

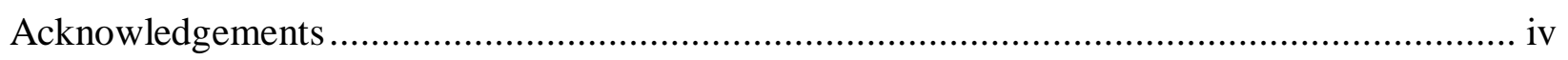

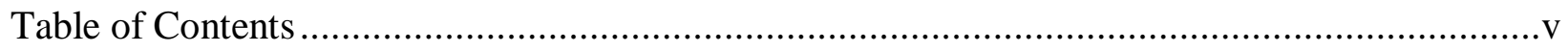

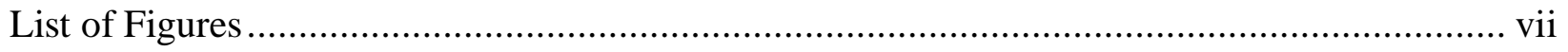

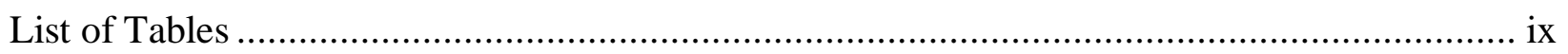

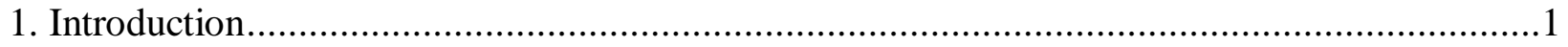

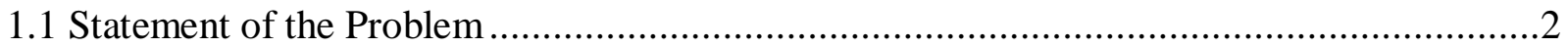

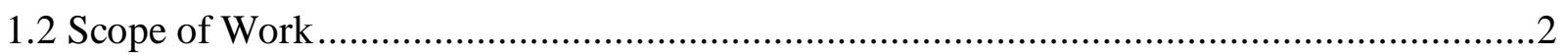

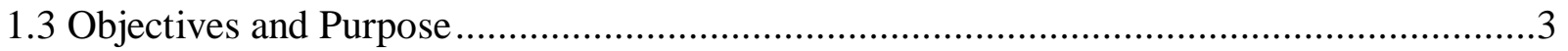

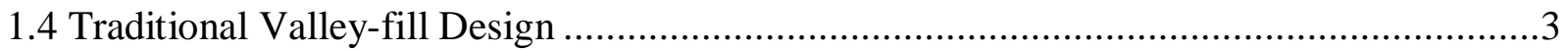

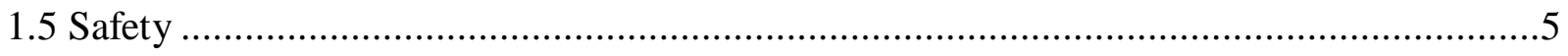

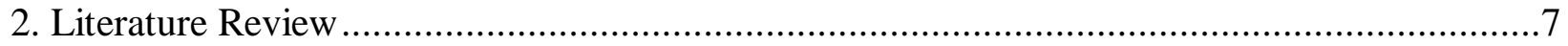

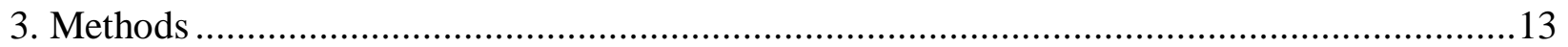

3.1 Regulatory Drivers Affecting Geomorphic Landform Design..................................13

3.2 Training and Conferences ............................................................................ 15

3.3 Step-by-Step Procedure and Method for Design ................................................... 15

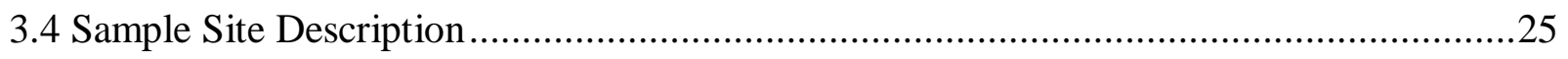

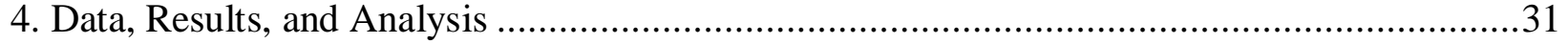

4.1 AOC Variance Valley-fill Design Analysis at Sample Site .......................................31

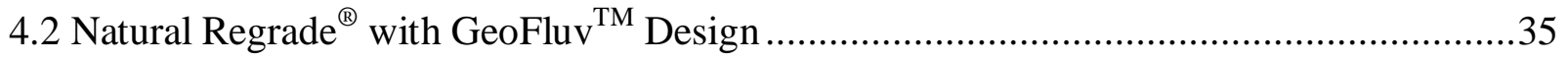

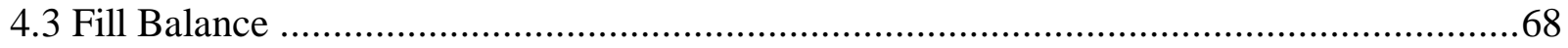

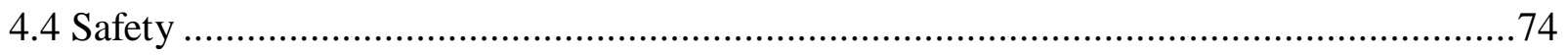

5. AOC Variance vs. Geomorphic Design Comparison........................................................75

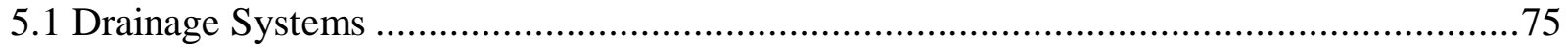

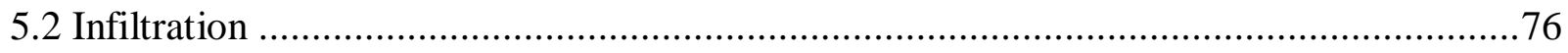

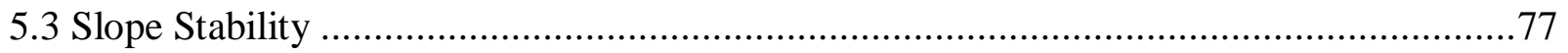

6. Summary, Conclusions, and Areas of Future Research ............................................... 78

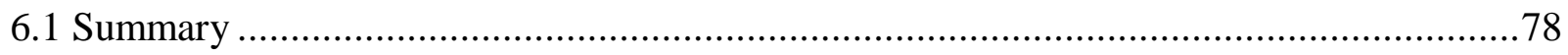




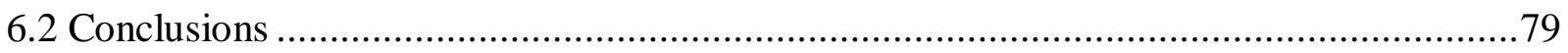

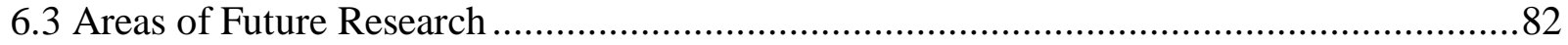

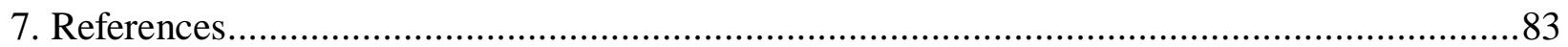




\section{List of Figures}

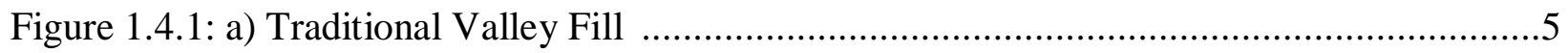

Figure 1.4.1: b) Traditional Valley Fill Profile .......................................................................

Figure 2.0.1: AOC Compared to Original Contour of Mountain ..............................................

Figure 2.0.2: a) Newly Constructed AOC Valley Fill ................................................................

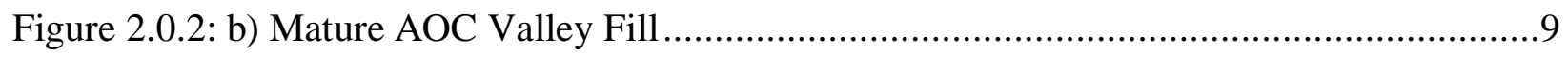

Figure 2.0.3: a) Surface Mining Site in Indiana Reclaimed using Natural Regrade ${ }^{\circledR}$..................12

Figure 2.0.3: b) Surface Mining Site Reclaimed using Natural Regrade ${ }^{\circledR}$..................................12

Figure 3.3.1: Natural Regrade ${ }^{\circledR}$ Global Settings and Default Values ........................................17

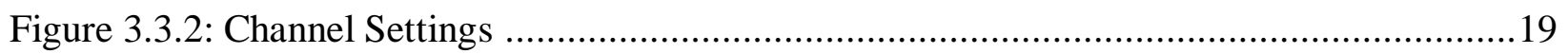

Figure 3.3.3: Draw Design Surface Options with Selected Options Used in Sample Site ...........21

Figure 3.3.4: Triangulate Options with Selected Options Used in Sample Site ..........................22

Figure 3.3.5: Contour Options with Selected Options Used with Sample Site ...........................23

Figure 3.3.6 Label Options with Selected Options Used with Sample Site .................................24

Figure 3.3.7: View and Edit Options for Created Drawing....................................................25

Figure 3.4.1: Sample Surface Mine Site Visit at a) Area Currently Being Mined ........................26

Figure 3.4.1: Sample Surface Mine Site Visit at b) Area Previously Reclaimed .........................26

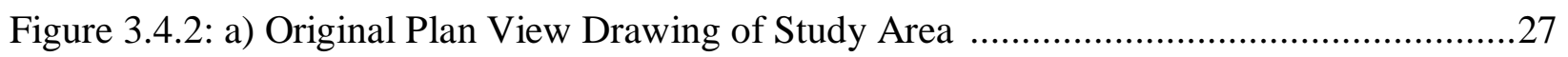

Figure 3.4.2: b) Original Topographic Relief of Study Area ...................................................28

Figure 3.4.3: a) Post-mined Plan View of Study Area ..........................................................29

Figure 3.4.3: b) Post-mined Topographic Relief of Study Area ................................................. 30

Figure 4.1.1: a) Post-mined "Pastureland" Valley Fill Profile at Sample Site .............................32

Figure 4.1.1: b) Labeled Features of Post-mined "Pastureland" Valley-fill at Sample Site ..........33

Figure 4.1.2: Sample Site Valley Fill Cross Section (East to West) ............................................34

Figure 4.1.3: Sample Site Valley Fill Cross Section (South to North) …………….....................34

Figure 4.1.4: Sample Site Valley Fill Bench Specifications ....................................................35

Figure 4.2.1: Subwatersheds Identified in the Valley-fill Study Site ........................................36

Figure 4.2.2: First and Largest Subwatershed Analyzed: "Subwatershed 1"...............................37

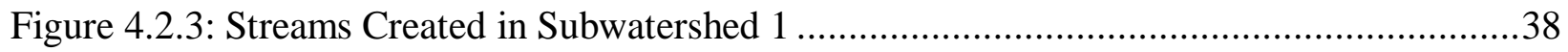

Figure 4.2.4: Subwatershed 1 with Labeled Created Streams .....................................................39

Figure 4.2.5: Completed Subwatershed 1 Geomorphic Valley-fill Design ................................40 
Figure 4.2.6: Second Subwatershed Analyzed: "Subwatershed 2" .....................................43

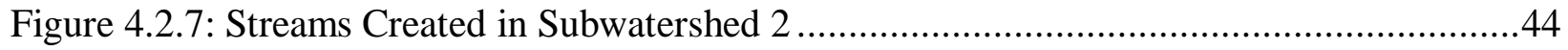

Figure 4.2.8: Subwatershed 2 with Labeled Created Stream ............................................45

Figure 4.2.9: Completed Subwatershed 2 Geomorphic Valley-fill Design .............................46

Figure 4.2.10: Third Subwatershed Analyzed: "Subwatershed 3" ......................................48

Figure 4.2.11: Streams Created in Subwatershed 3 .....................................................49

Figure 4.2.12: Subwatershed 3 with Labeled Created Stream ...........................................50

Figure 4.2.13: Completed Subwatershed 3 Geomorphic Valley-fill Design ............................51

Figure 4.2.14: Fourth Subwatershed Analyzed: "Subwatershed 4" ........................................53

Figure 4.2.15: Streams Created in Subwatershed 4 ....................................................54

Figure 4.2.16: Subwatershed 4 with Labeled Created Streams .............................................55

Figure 4.2.17: Completed Subwatershed 4 Geomorphic Valley-fill Design ...........................56

Figure 4.2.18: Fifth Subwatershed Analyzed: "Subwatershed 5" .......................................58

Figure 4.2.19: Streams Created in Subwatershed 5 ..........................................................59

Figure 4.2.20: Subwatershed 5 with Labeled Created Stream ..........................................60

Figure 4.2.21: Completed Subwatershed 5 Geomorphic Valley-fill Design ..........................61

Figure 4.2.22: Last Subwatershed Analyzed: "Subwatershed 6" ..........................................63

Figure 4.2.23: Streams Created in Subwatershed 6 .....................................................64

Figure 4.2.24: Subwatershed 6 with Labeled Created Stream ..........................................65

Figure 4.2.25: Completed Subwatershed 6 Geomorphic Valley-fill Design ...........................66

Figure 4.2.26: Stream Channels Created Using Fluvial Geomorphic Principles .....................68

Figure 4.3.1: Contoured Edited GeoFluvTM Surface Created at Sample Site .........................70

Figure 4.3.2: Colored Contoured Edited GeoFluv ${ }^{\mathrm{TM}}$ Surface Created at Sample Site ...............71

Figure 4.3.3: Completed 3-Dimensional Geomorphic Landform Valley-fill Design .................72

Figure 4.3.4: Completed Projected 3-Dimensional Geomorphic Landform Valley-fill Design ...73

Figure 4.3.5: Completed Rotated 3-Dimensional Geomorphic Landform Valley-fill Design .....73

Figure 5.1.1: AOC Valley Fill Face with Labeled Drainage Structures ................................75 


\section{List of Tables}

Table 4.2.1: Channel Data for Subwatershed 1 Channels Main, R3, R3R2 and R3R2L1 ..........41

Table 4.2.2: Channel Data for Subwatershed 1 Channels R3R1, L3, L3R1 and L2 ..................41

Table 4.2.3: Channel Data for Subwatershed 1 Channels L2R1, R2, R2L1 and R1 .................42

Table 4.2.4: Channel Data for Subwatershed 1 Channel L1 and Total Summary Data .............42

Table 4.2.5: Channel Data for Subwatershed 2 Channel Main and Total Summary Data ..........47

Table 4.2.6: Channel Data for Subwatershed 3 Channel Main and Total Summary Data ..........52

Table 4.2.7: Channel Data for Subwatershed 4 Channels Main, L1, and Total Summary Data ..57

Table 4.2.8: Channel Data for Subwatershed 5 Channel Main and Total Summary Data ..........62

Table 4.2.9: Channel Data for Subwatershed 6 Channel Main and Total Summary Data ..........67

Table 6.0.1: Geomorphic Landform Design Data of Sample Site .......................................80

Table 6.0.2: AOC Variance Design Data of Sample Site ................................................... 80 


\section{Introduction}

Concerns of detrimental environmental impacts originating from mountaintop surface mining and valley fill construction are of constant debate, resulting in a plethora of lawsuits (e.g. Hasselman, 2002, Davis and Duffy, 2009) and scientific studies throughout Appalachia (e.g. Hartman et al., 2005; Pond et al., 2008; Ferrari et al., 2009). State and Federal regulations have been promulgated to control environmental impacts associated with mountaintop mining and valley fill construction through the Surface Mining Control and Reclamation Act (SMCRA) and the Clean Water Act (CWA). West Virginia has primacy for regulatory enforcement and, thus, must meet stringent regulatory standards for valley fill construction.

These regulations have resulted in geotechnically stable designs of valley fills with runoff management. However, major environmental concerns have resulted, specifically the loss of headwater stream length, increased flooding risk, and degraded water quality in communities downstream. The predicted headwater stream loss in West Virginia is approximately $3,200 \mathrm{~km}$ by 2012, thus impacting the ability of West Virginia to support high quality and unique aquatic species (USEPA, 2005). Studies have shown that streams located below valley fills often have elevated conductivity levels, resulting from water contact with the overburden (Hartman et al., 2005; Pond et al., 2008). Additionally, changes in thermal regime, chemistry, and sedimentation are potential impacts for streams below valley fills (USEPA, 2005). One promising innovative technique used to lessen these impacts involves fluvial geomorphic landform design that incorporates mature landform shapes into the designs. These landform designs add variability and aid in establishing a site with a long-term hydrologic balance. 


\subsection{Statement of the Problem}

Conventional valley fill surface mining techniques are being researched by organizations, including the U.S. Department of Interior's Office of Surface Mining, Reclamation, and Enforcement, and by the U.S. Geologic Survey. The AOC valley-fill designs provide the opportunity for improvement in the areas of steam loss, surface water infiltration and runoff, and downstream water quality. One promising post-mining reclamation approach, termed geomorphic design, is producing beneficial results that lack in the current AOC method.

\subsection{Scope of Work}

The following scope of work details the research method developed and implemented for this project. The project scope included the following tasks:

- Site Visit: A site visit was made to a working surface coal mine in southern West Virginia in order to collect data including soil samples, design documents, and photographs of current and previous mined landscapes.

- Literature Review: A comprehensive literature review of the current federal and state mining reclamation laws was completed, followed by a review of published scientific literature covering reclamation topics related to AOC and geomorphic design.

- Method Develop: A research approach was developed to study the existing valley-fill design and construction requirements, to determine opportunities for incorporating geomorphic design. Computer training was completed to learn the design process and software tools. A step-by-step procedure was documented for producing a geomorphic design in Appalachia, this included identifying modeling parameters and properties specific to the study site. 
- Data Evaluation: This work step involved developing metrics to compare and contrast the existing AOC design to various prototype geomorphic designs.

- Results and Recommendations: The thesis culminates with a summary of the comparative benefits and challenges of each design method and presents areas for further study.

\subsection{Objectives and Purpose}

The work discussed in this dissertation incorporates landforming into the traditional valley-fill design process, thus providing an alternative to the conventional reclamation techniques. The objectives of this research were to:

- Use an Appalachian surface mine site to evaluate valley-fill design options.

- Perform a geomorphic landform design using Carlson ${ }^{\circledR}$ Natural Regrade ${ }^{\circledR}$ with GeoFluv $^{\mathrm{TM}}$ and landforming principles.

- Compare the geomorphic landform design outputs with the conventional approximate original contour valley-fill design outputs.

An alternative reclamation design was created and evaluated to determine if an effective and implementable valley fill could be designed using Carlson's Natural Regrade® software following the Geofluv ${ }^{\mathrm{TM}}$ method as applied to mountainous terrain in the central Appalachian region of West Virginia.

\subsection{Traditional Valley-fill Design}

Appalachian surface mines are reclaimed to the Approximate Original Contour (AOC) according to the Surface Mining Control and Reclamation Act (SMCRA) of 1977. Overburden, 
the material that lies above the coal seam, is placed using unconsolidated end dumping methods. Loosely placing overburden by end dumping has the potential to create unsafe conditions, especially in mountainous terrain where the end dump piles have significant depth. The material that has been dumped has little to no compaction and therefore lacks guaranteed stability. Loose materials also have a higher potential for internal erosion known as piping or suffusion. Piping is the transport of water and soil particles through channels in a mass of soil. Piping in channels exists as a result of void spaces in the soil (Martin-Duque et al. 2010). Subsurface particle transport in loosely laid materials can also result in areas with excess pore pressure which can threaten the stability of the structure as well as the safety of any operators working on or around the structure. Loose materials have high void ratios which in turn can lead to settlement, and ultimately a change in the geometry of the structure. This change in geometry can affect the stability of the slopes and cause unsafe conditions for operators.

Maintenance can also be an issue in traditional AOC construction techniques due to surface erosive forces. The created AOC landforms are not necessarily stable landforms. Frequently, they are not at equilibrium with erosive forces and surface particle transport, as erosion, can occur.

Traditional surface mine reclamation practices also cause many other concerns besides instability. Typical valley-fill designs include uniform slopes with terraces and down-drains that appear un-natural and not aesthetically pleasing. Also, these valley fills have caused major environmental concerns, specifically the loss of headwater stream length, increased flooding risk, and degraded water quality in communities downstream (McQuaid, 2009). A profile view of a typical valley fill is shown in Figure 1.4.1. 

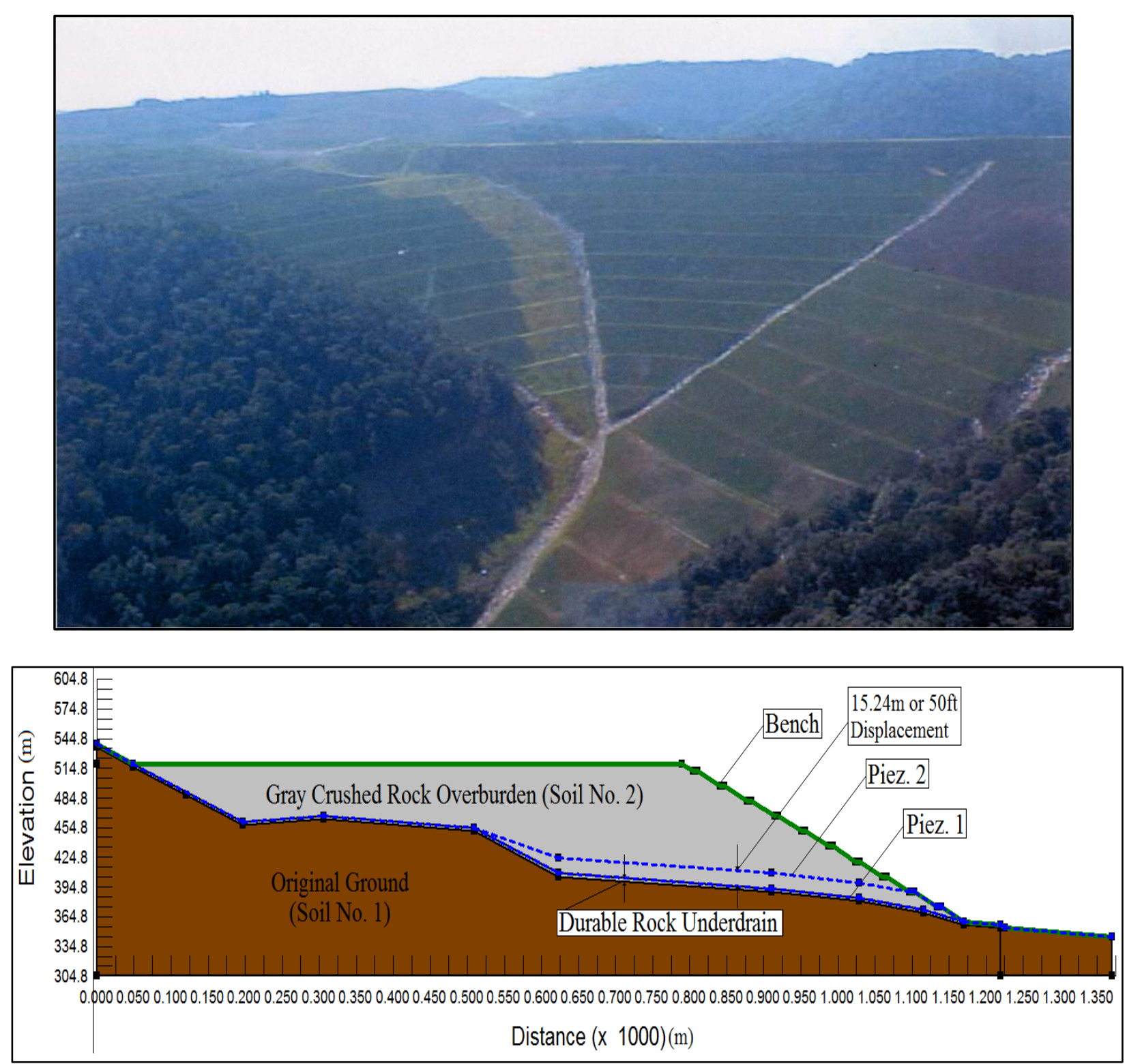

Figure 1.4.1: a) Traditional Valley Fill and b) Traditional Valley Fill Profile

\subsection{Safety}

Many safety issues involved with surface mining are thwarted by each operator's own concern, care, and experience. However, it is imperative to consider that surface mining in West Virginia is particularly unique as a result of its rough and often exceedingly steep terrain. The condition of the terrain contributes to the difficulty of both mining and reclaiming mountaintop 
removal mine sites. Many safety studies have been performed by the Mine Safety and Health Administration (MSHA), National Institute for Occupational Safety and Health (NIOSH) and other organizations in an attempt to improve technology and regulations, therefore making surface mining safer.

Mine safety issues involved with fluvial geomorphic reclamation design should be comparable to safety issues involved with AOC designs since the slope construction methods are similar. State and Federal regulations which control mine reclamation using the AOC approach have resulted in geotechnically stable designs of valley fills constructed using waste rock overburden. However, when these valley fills are constructed, there is a significant loss of headwater stream length as well as an associated increased flooding risk. Subsequently, it is necessary to consider operator safety, environmental concerns, and alternative design methods for surface mining.

Fluvial geomorphic landform design, when utilized as a valley fill alternative, has promising potential to lessen the environmental impacts of surface mining and reduce the critical nature of mining accidents at these sites. The steep sloped natural terrain of Appalachia offers a variety of safety concerns, and therefore requires further investigation. Critical safety concerns involved with performing the construction of geomorphic landforms in mountaintop mine site reclamation were analyzed during this project. 


\section{Literature Review}

Reclamation by AOC design is the traditional method practiced in the central Appalachian region of the United States. These promulgated design requirements were needed to provide standards and controls. Prior to the Surface Mining Control and Reclamation Act (SMCRA), adopted into law in 1977, non-designed earth moving practices resulted in spoil materials being deposited into valleys, hillsides, and into ephemeral streams without consideration for erosion, geotechnical stability, seepage, and hydrology. Unfortunately, the end results included slope washes, loss of topsoil, and stream siltation. Figure 2.0.1 is an illustration of the AOC reclamation method with respect to the original contour of the mountain.

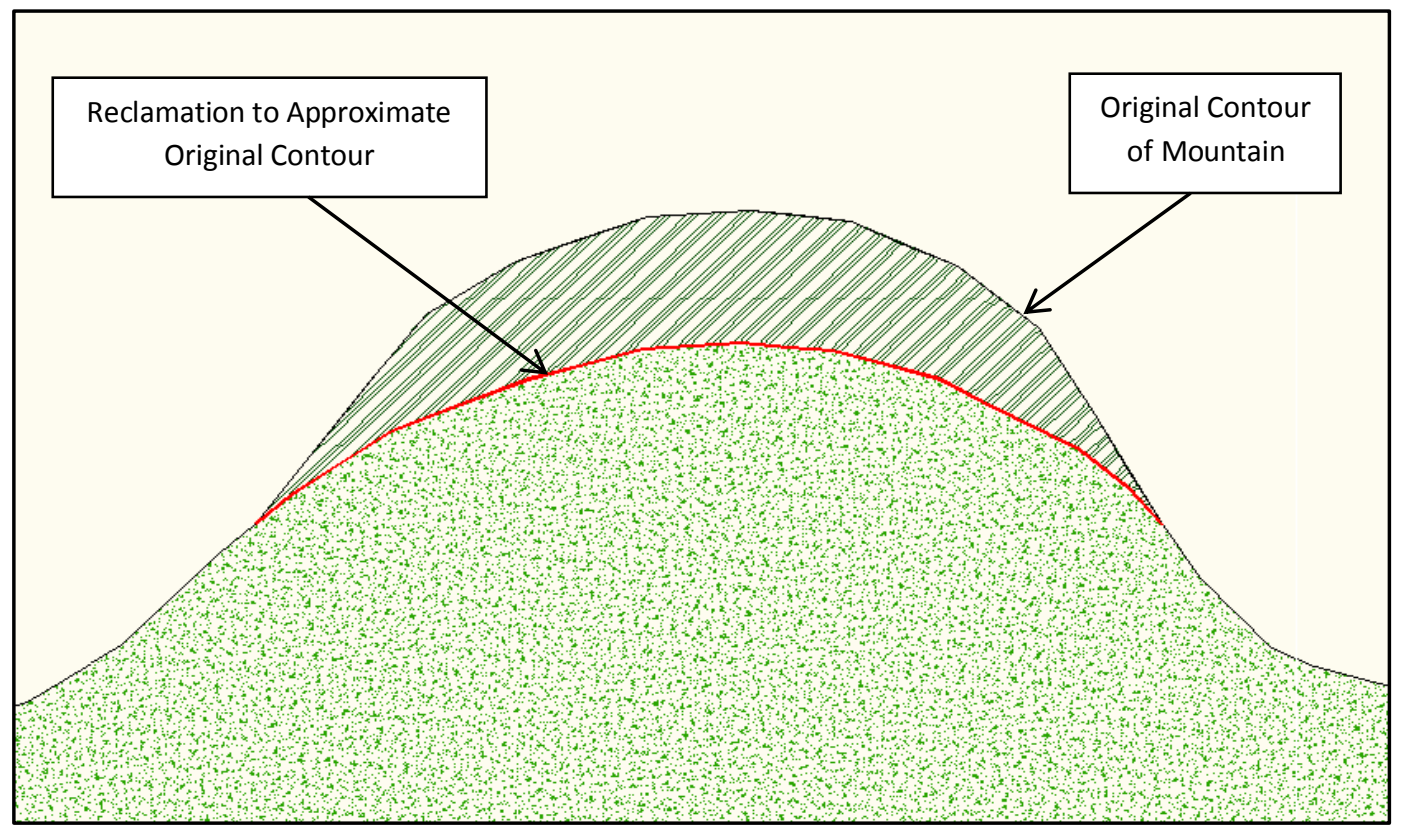

Figure 2.0.1: AOC Compared to Original Contour of Mountain

In West Virginia, the Approximate Original Contour guidelines are promulgated by West Virginia Surface Mining Reclamation Regulations (WVSMRR), Code of State Regulations (CSR) $\$ 38$ which require slope profile configurations constructed by the traditional backfilling technique. It is also required that grading of disturbed areas have a final profile which, in effect, 
closely resembles the general surface configuration of the land prior to mining. The post mining slope design is intended to ensure slope stability, control drainage, complement the drainage pattern of the surrounding terrain, and prevent stream sedimentation. These requirements are comprehensive, covering the drainage pattern of the surrounding terrain, highwalls, and spoil piles. Special circumstances and permit variances can be approved by regulatory agencies for specific areas that will not comply with AOC regulations. In addition, the West Virginia Department of Environmental Protection (WVDEP) and the US Environmental Protection Agency (EPA) implement the Clean Water Act of 1972 through the National Pollution Discharge and Elimination System (NPDES) to provide requirements for drainage and sediment control for the quality of the discharged runoff on the disturbed area.

The AOC requirements result in the typically profiled valley fill slope shapes exhibiting uniform benches, planar slopes having unvarying contours with perimeter and/or center surface water ditches. To date, the AOC guidelines provide help in the reduction in environmental degradation of mountain streams and an increase in the stability of slopes on the reclamation sites. In West Virginia, the reclamation vegetation efforts using select grasses and hardwoods have proven somewhat effective in concealing the planar slope profiles and surface drainage structures (Skousen and Venable, 2007; Groninger et al., 2007). The effectiveness of post mine land use implemented by the mining industry has been successful to an extent and as tree canopy matures the slopes appear natural, to some degree. However, many public and industry individuals believe that this traditional, planar reclamation method can be improved to appear more natural and decrease the drawbacks associated with it. Figure 2.0.2 shows a newly constructed traditional valley fill and a mature traditional valley fill. 

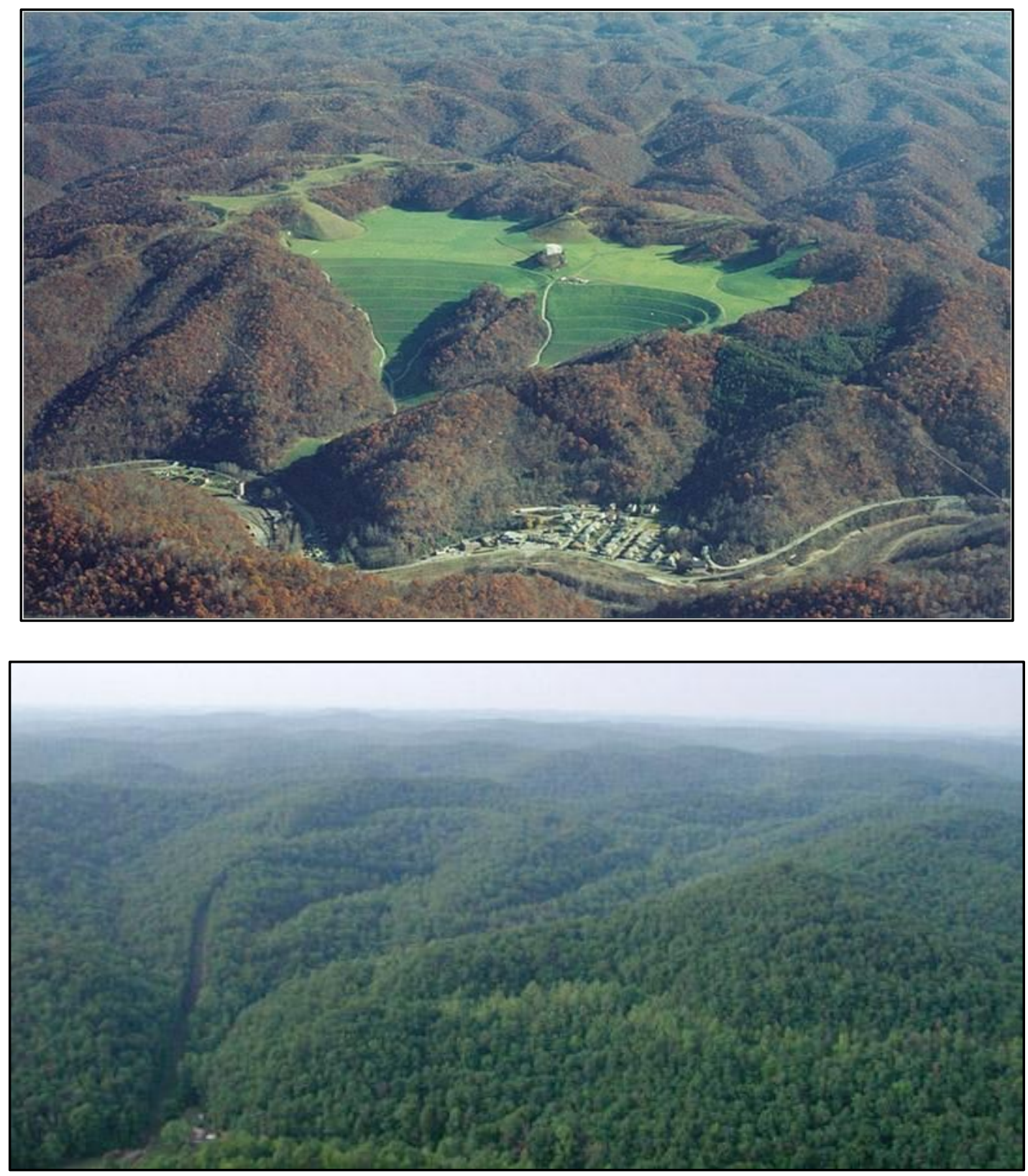

Figure 2.0.2: a) Newly Constructed AOC Valley Fill and

\section{b) Mature AOC Valley Fill}

The geotechnical safety benefits of the AOC valley-fill method requirements are not able to balance with the loss of streams and changes in watershed sizes that subsequently occur. The need for a balanced surface mine reclamation method have opened the door for improvements. Under natural conditions, landforms develop a balance between erosive and resistance forces, 
resulting in a system in equilibrium with low erosion rates. The fluvial geomorphic landform design approach attempts to design landforms in this steady-state condition, considering longterm climatic conditions, soil types, slopes, and vegetation types (Toy and Chuse, 2005; Bugosh, 2009). This design approach may provide the balance between valley fill construction stability and surface hydrologic reclamation needs.

State and Federal regulations directing mine reclamation using the AOC approach have resulted in geotechnically stable designs of valley fills constructed using waste rock overburden. Environmental concerns at mountaintop mining sites abound because of the loss of headwater stream length and increased flooding risk. One promising technique to lessen the impacts involves fluvial geomorphic landform design applied to the waste rock fill and slope profiles. These innovative geomorphic landforms designs are often created using Carlson's Natural Regrade $^{\circledR}$ with GeoFluv ${ }^{\mathrm{TM}}$ software.

Carlson $^{\circledR}$ describes its Natural Regrade ${ }^{\circledR}$ software as a software that provides a natural, cost-effective method to bring sustainability to disturbed lands, whether altered from mining or development $\left(\right.$ Carlson $\left.^{\circledR}, 2011\right)$. Natural Regrade ${ }^{\circledR}$ utilizes the GeoFluv $^{\mathrm{TM}}$ method for landform design and minimizes material handling and surface erosion while creating sustainable landforms. It applies fluvial geomorphic principles to upland landform design and creates a landscape design that mimics the functions of the natural landscape that would have naturally evolved over time. The result is a stable hydrologic equilibrium that occurs naturally (Carlson ${ }^{\circledR}$, 2011).

The approach of GeoFluv ${ }^{\mathrm{TM}}$ principles is to identify the type of drainage network, stream channels and valleys, which would form over a long time given the earth materials, relief, and climate of the site to achieve a stable landform, and to design and build that landform. The 
resulting slopes and stream channels that are created are stable because they are in balance with these conditions. It is a reclamation alternative to the traditional designs with uniform slopes with terraces and down-drains. Rather than fight the natural forces that shape the land, GeoFluv $^{\mathrm{TM}}$ helps create a landscape that harmonizes with these forces (Carlson $\left.{ }^{\circledR}, 2011\right)$. Carlson lists the advantages of Natural Regrade ${ }^{\circledR}$ with GeoFluv ${ }^{\mathrm{TM}}$ as:

- Natural Regrade ${ }^{\circledR}$ software replaces lengthy and tedious manual calculations with fast, efficient design

- Natural Regrade ${ }^{\circledR}$ frees the user's creative design energies

- View topographic maps and three-dimensional images of the resulting landscape design

- One-button volumes and cut/fill material balance calculations for designs gives instant colored-coded feedback

- Rapid evaluation of many landscape design alternatives allows the user to select the optimum landscape design for bond alternatives, changing mine plans, land use, etc. Natural Regrade ${ }^{\circledR}$ with GeoFluv ${ }^{\mathrm{TM}}$ was created by Nicholas Bugosh and has received a Silver Award in the Services Category of Intermat's award series. Also, the U. S. Department of the Interior's Office of Surface Mining (OSM), Reclamation and Enforcement has identified Carlson $^{\circledR}$ Natural Regrade ${ }^{\circledR}$ as a 'TIPS Core Software'. Figure 2.0.3 shows an example of a completed surface mine site that was reclaimed using geomorphic landforms design principles. 

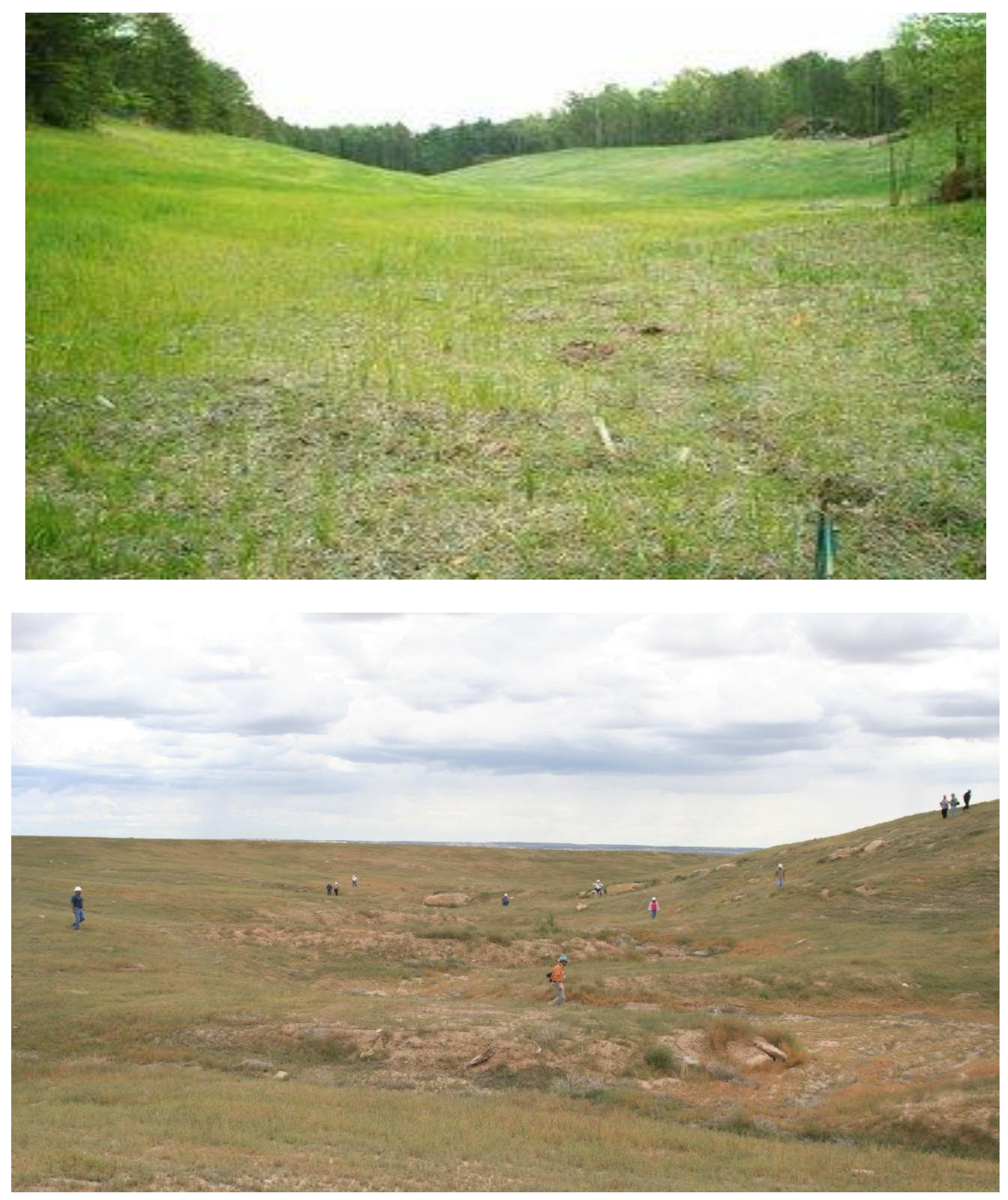

Figure 2.0.3: a.) Surface Mining Site in Indiana Reclaimed using Natural Regrade ${ }^{\circledR}$ b.) Surface Mining Site Reclaimed using Natural Regrade ${ }^{\circledR}$ 


\section{Methods}

\subsection{Regulatory Drivers Affecting Geomorphic Landform Design}

Challenges associated with implementing the geomorphic landform approach in the Central Appalachia Region extend beyond the complexity of designing and constructing mature landforms in steep terrain. Current, civil engineering-based regulations for meeting AOC and Surface Water Runoff Analysis (SWROA) do not readily support this nontraditional design approach, and perceived initial construction costs are greater than traditional designs (Michael et al., 2010). Also, without the undeniable evidence of the benefits of a geomorphic landform reclamation site in Central Appalachia compared to the traditional method, industry resistance from coal companies and regulators alike is inevitable. Therefore, the traditional AOC method and the new geomorphic design method must be compared to determine the benefits and disadvantages of each.

The geomorphic landform design procedure builds a drainage network using a reference landform approach. With this procedure, a reference watershed must be identified and characterized to begin. The information that is necessary to inform successful includes the main channel slope and landform profile shape, drainage density and area, and channel characteristics design (Toy and Chuse, 2005; Eckels and Bugosh, 2010). Each of these design requirements is discussed in detail below.

The main channel is a vital part of the subwatershed design because each of the created tributaries stem off of the main channel. Also, the profile of the main channel affects slopes and erosion of the landforms. As the main channel slope increases, the stream power and erosion potential increase (Toy and Chuse, 2005). Longitudinal profile shapes of the landforms must also be considered since the concave shape differs among headwater and downstream locations. 
In mountainous terrain, the nature of slope profiles develop into compound surface profiles. These profiles exhibit steep convex slopes at the head of the valley and progressively transition into a concave form gradually tapering to a uniform profile. The development of natural stream design is effected by the fluvial influence stream cutting and surfical erosion and the rill to gulley erosion all couple to effect. Valley fills end up as unique landforms that exhibit geotechnical stability; however, they lack the ability, as currently regulated, to incorporate surface hydrologic features to enable stream replacement or development.

Drainage density is a measure of the average stream channel spacing and results from flow interactions with sediment and soil, vegetation, topography, and weather variables (Bugosh, 2004; Toy and Chuse, 2005). For a given reference landform, the drainage density describes the drainage network that can be supported without significant aggradation or erosion (Bugosh, 2004). The fluvial geomorphic design approach assumes a dendritic pattern, which is typical for unconsolidated materials (Toy and Chuse, 2005; Eckels and Bugosh, 2010). Natural channels vary in characteristics depending on its location in the watershed. Headwater streams are often steep (>4\% slope), characterized as " $\mathrm{A}$ " channels as defined by the Rosgen classification system (Rosgen, 1996), and relatively straight (sinuosity $=1.0-1.2)$, and down-stream channels have a lower gradient (<4\% slope), C-channels, and increased sinuosity (>1.2; Rosgen, 1996).

The stream characteristics that must be considered when designing systems that will properly manage both flow and sediment discharge are bankfull width, width to depth ratio, sinuosity, meander belt width, A-channel reach length and sinuosity (Eckels and Bugosh, 2010). A-channel reach length is defined as the distance of one-half of a meander length in steep channels. Ridge to head of channel distance defines the length required to form concentrated flow, advising the channel head location in reference to the watershed boundary. 


\subsection{Training and Conferences}

To have properly created the geomorphic landform valley-fill designs, I attended a training on Carlson ${ }^{\circledR}$, s Natural Regrade ${ }^{\circledR}$ with GeoFluv ${ }^{\mathrm{TM}}$ software by Nicholas Bugosh (Natural Regrade ${ }^{\circledR}$ and Geofluv ${ }^{\mathrm{TM}}$ creator) at West Virginia University, and also a training on Carlson ${ }^{\circledR,}$ s Natural Regrade ${ }^{\circledR}$ with GeoFluv ${ }^{\text {TM }}$ software by TIPS (Technical Innovation and Professional Services) at the Office of Surface Mining in Pittsburgh, Pennsylvania. I have also been guided by my advisors as well as professionals that use Carlson ${ }^{\circledR}$ 's Natural Regrade ${ }^{\circledR}$ software in the industry.

During my graduate schooling and research, I attended the Society for Mining, Metallurgy, and Exploration Annual Meeting in Seattle, Washington, International Conference on Ground Control in Mining in Morgantown, West Virginia, and made a presentation about my research at the International Conference on Solid Waste Technology and Management in Philadelphia, Pennsylvania.

\subsection{Step-by-Step Procedure and Method for Design}

To create a valley fill alternative, the topographic drawing containing the original contour lines was opened in Carlson ${ }^{\circledR}$ 's Natural Regrade ${ }^{\circledR}$ with AutoCAD. The mine property boundary was then established and drawn using a closed 2D polyline. The property was broken into subwatersheds in order to perform a proper balanced Natural Regrade ${ }^{\circledR}$ analysis. Each subwatershed was separated using a closed 2D polyline around its boundary.

The largest subwatershed was chosen to do a Natural Regrade ${ }^{\circledR}$ design on first because it was the main subwatershed for which all the surrounding subwatersheds will be designed around. The main channel was drawn in the main watershed using a 2D polyline. The head elevation of the main channel must be greater than the base elevation and the main channel must 
extend outside of the watershed boundary on one end. Each of the channels, including the main channel must begin within the ridge to head-of-channel distance, which is a variable input in the settings. The default for the ridge to head-of-channel distance setting is $80 \mathrm{ft}$. We used this default setting to create the Natural Regrade ${ }^{\circledR}$ design for the sample site due to a lack of on-site data because of current mining. After the main channel was drawn, the tributary channels were drawn in a dendritic pattern. Each tributary must begin within the ridge to head-of-channel distance of the boundary and must end very close to the main channel, but not connected to it. All of the channels drawn must satisfy the drainage density, which is a variable input in the settings. The drainage density is a very important part of a Natural Regrade ${ }^{\circledR}$ design. It is calculated by the valley length divided by the watershed area. The default setting for the drainage density is $100 \mathrm{ft} / \mathrm{ac}$ with a range of $\pm 20 \%$. Therefore, the drainage density of each channel must range from $80-120 \mathrm{ft} / \mathrm{ac}$.

Added tributary channels contribute to the drainage density of the main channel, which is also the case for channels that are added onto tributary channels. These channels affect the drainage density of the tributary channel that the channels drain into and the main channel. Also, the channel length and location affect the drainage density. Therefore, if a channel has too high or too low of a drainage density, the channel can be moved, lengthened, shortened, or removed in order to achieve a drainage density within the selected range. More tributary channels will need to be added to the main channel closer to its mouth in order to satisfy the target drainage density, while less tributary channels will be needed at the head of the main channel to meet the drainage density requirement. The drainage density is important to the Natural Regrade ${ }^{\circledR}$ design because if the drainage density is too high or too low, erosion will occur until the correct drainage density is achieved. 
There are numerous settings that can be customized by the user to match the site in which the geomorphic reclamation design is being created. Figure 3.3.1 shows a list of the global settings in Natural Regrade ${ }^{\circledR}$ along with their default values. All of these values can be changed so that the design can blend in with the natural ridges and streams of the site and the area surrounding the site.

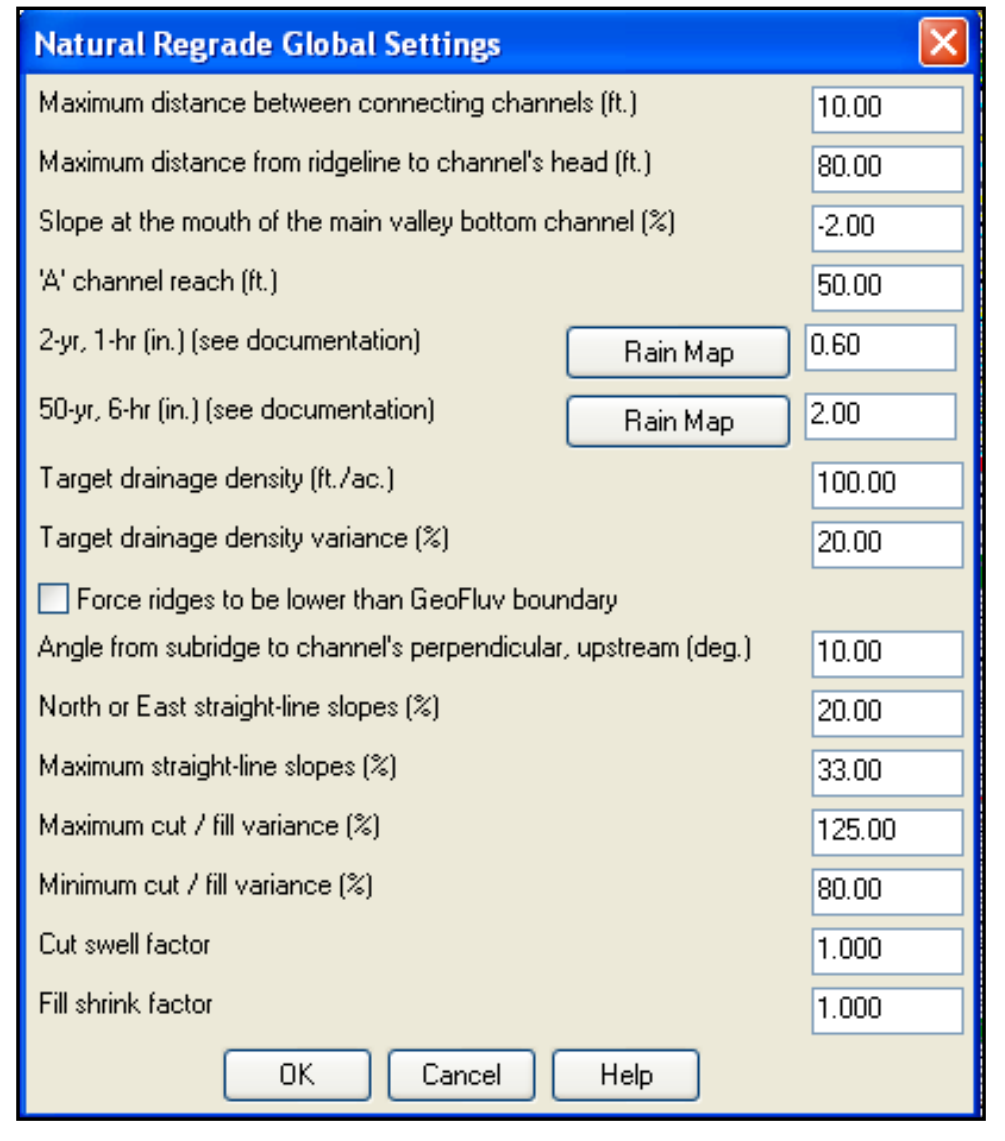

Figure 3.3.1: Natural Regrade ${ }^{\circledR}$ Global Settings and Default Values

Two of the global settings that were drastically changed for the sample site were that the $2 \mathrm{yr}, 1$ hr rainfall changed from 0.6 in. to $1.41 \mathrm{in}$. and the $50 \mathrm{yr}, 6 \mathrm{hr}$ rainfall changed from $2.0 \mathrm{in}$. to 4.03 in. The default rainfall values are based on semi-arid regions of the United States where 
precipitation is lower as opposed to the higher precipitation region of the United States in which the sample site is located, based on type II storm and precipitation data.

Once the watershed boundary, main channel, and tributary channels have been drawn on the original topographic drawing, a Natural Regrade ${ }^{\circledR}$ design can be created. Once Natural Regrade $^{\circledR}$ is opened with AutoCAD, the "Design Natural Regrade" option is chosen under the Natural Regrade ${ }^{\circledR}$ tab. This opens the Carlson ${ }^{\circledR}$ GeoFluv $^{\mathrm{TM}}$ box on the left side of the AutoCAD drawing. The first step is to select the GeoFluv ${ }^{\mathrm{TM}}$ boundary tab and then click the watershed boundary that was drawn previously. If all requirements were met, the program will state that the boundary has been accepted. If all of the requirements were not met, then it will not accept the boundary and it will state what error occurred or what needs to be fixed. Once the boundary is accepted, the select main channel tab is selected. Then the main channel which was drawn previously is selected. Next, the program asks if the user would like to choose the transition point of the main channel or if the user would like to have the program choose it. The transition point of a channel is where the stream changes from an A-channel to a sinusoidal channel. For the sample design, the program was allowed to choose the transition point of the main channel and the tributary channels. Once the main channel is selected, the valley length and the drainage density are calculated.

Next, the surface for elevations must be chosen by clicking on the surface for elevations tab. The program then asks if the user would like to choose an existing TIN file or create a new one by selecting the entities in the drawing. TIN files are used for storing triangulated irregular networks. Due to never making a TIN file of the sample site, all of the entities were chosen from the AutoCAD drawing with the original topography to make a new TIN file for the surface for 
elevations. Once the TIN file was created, the head and base elevations of the main channel were calculated and shown in the box under the select main channel tab.

Everything was completed in the setup tab, so the channels tab was clicked. Since the main channel had already been input into the program, all of the current channel settings and data for the main channel were displayed. The settings for the main channel that were displayed include the upstream slope (\%), maximum water velocity ( $\mathrm{ft} / \mathrm{s})$, and width to depth ratio. There are other channel settings that could be changed in order for the user to customize the channels. These channel settings are shown below in Figure 3.3.2.

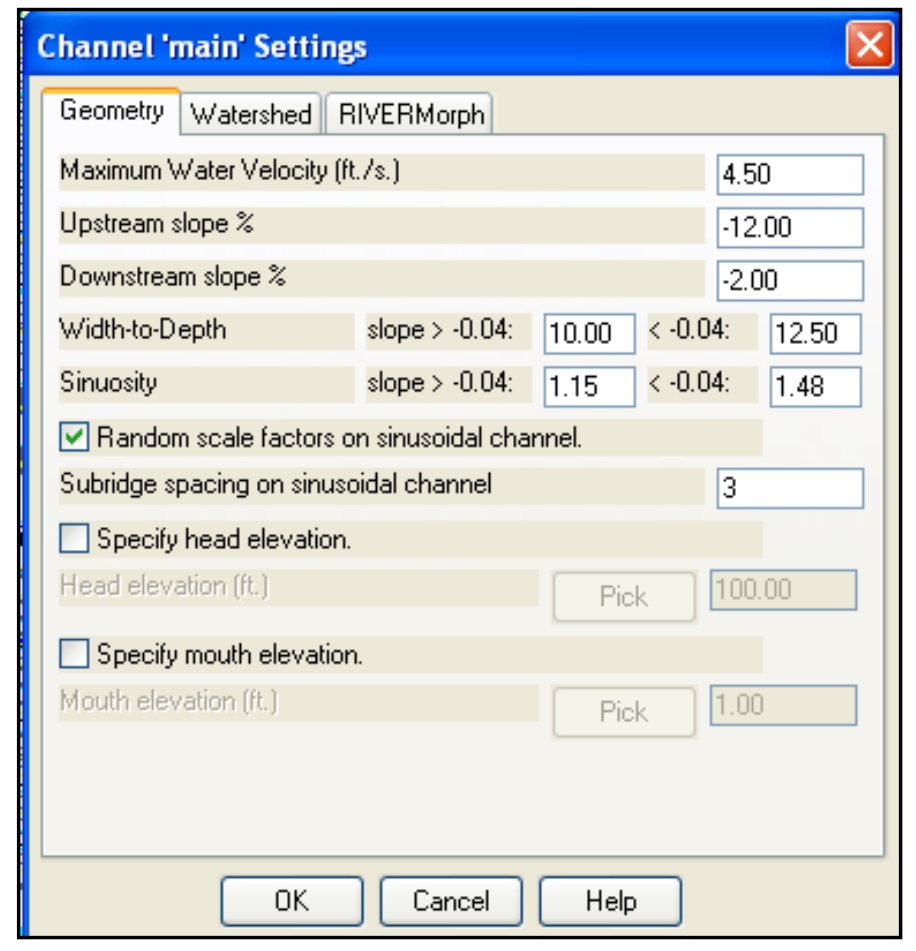

Figure 3.3.2: Channel Settings

All of the tributary channels had to be added individually into GeoFluv ${ }^{\mathrm{TM}}$. The add tab was clicked and then the channel was clicked. Just like the main channel, the program asked the user if the transition point would be chosen by the program or by the user. For the sample site, 
the program was allowed to choose the transition points on all of the channels. As each channel was added, the data and drainage density of the channel was displayed in the box. The drainage density of the main channel as well as the channels that were previously added changed as more channels were added. After all of the channels were added, it was necessary to check to make sure that all of the channels were within the target drainage density range. The arrow beside the channel name was used to check on the drainage density of each channel. If the drainage density of one or more channels was not within the target drainage density, the drainage density would appear red as opposed to green and the channel would need to be altered until it was within the target drainage density range. The channels could be moved, shortened, lengthened, deleted, or another channel added to it in order to achieve the target drainage density.

The output tab was where the user could actually see the valley-fill design implemented. The user could click the preview tab to see where the ridges, in yellow, and the valleys, in light blue, would be located. If the location of the ridges and valleys were satisfactory, the user could close the preview and click the draw design surface tab so that the program would draw the design surface on the drawing. Once this tab was clicked, a new box appeared and many options were shown. These user options included the layers in which the channels and ridges would be located and whether to triangulate and contour the drawing. The draw design surface options are shown in Figure 3.3.3 and the options that were used in the sample site design surface are chosen. 


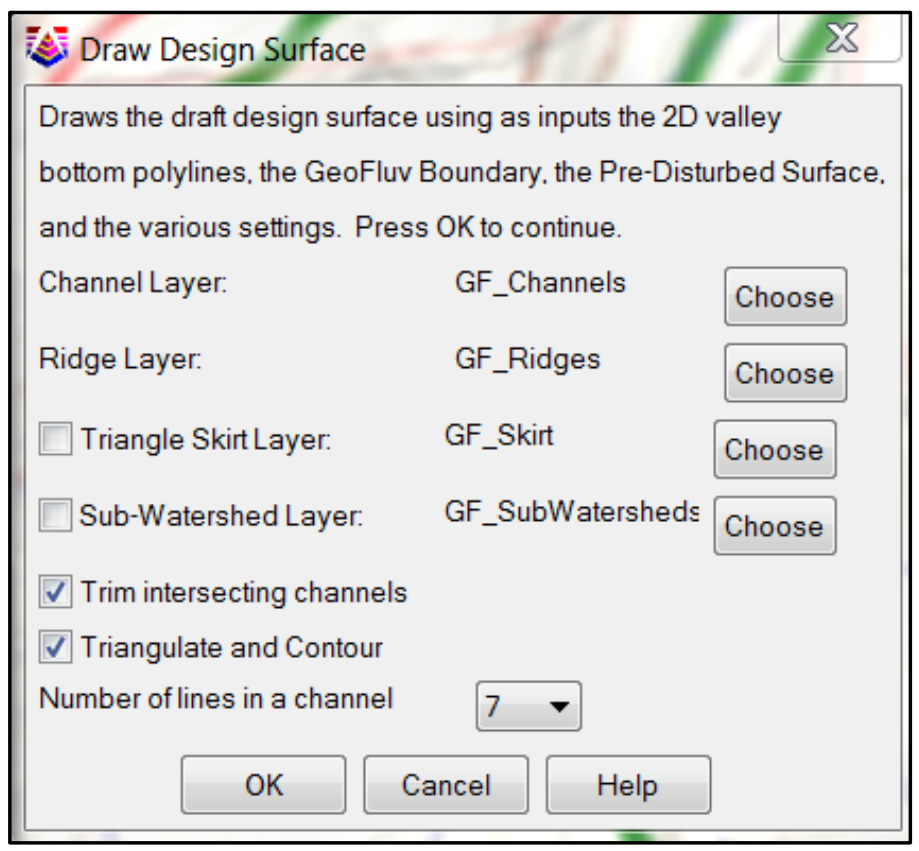

Figure 3.3.3: Draw Design Surface Options with Selected Options Used in Sample Site

Once the options were chosen, the $\mathrm{OK}$ tab was clicked. Next, the triangulate and contour from TIN box appeared automatically. This box contained three tabs of options that the user could customize the triangulation, contours, and labels of the drawing design surface. These options included writing the triangulation file of the design surface, the contour interval, and labeling the contours. Figure 3.3.4 shows the options that were under the triangulate tab and the options that were chosen for the sample site design surface. 


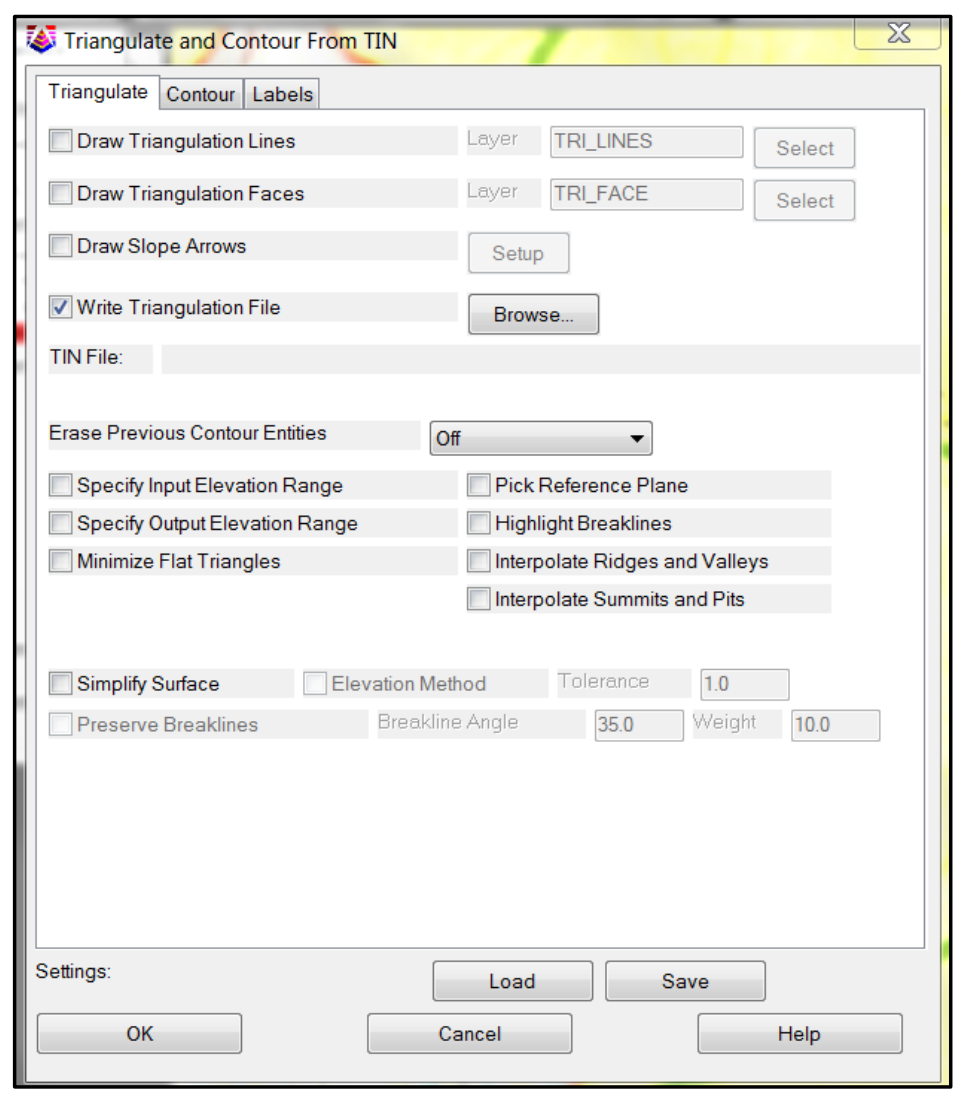

Figure 3.3.4: Triangulate Options with Selected Options Used in Sample Site

Figure 3.3.5 shows the contour options in the triangulate and contour from TIN box. It also shows the options that were selected with the sample site. 


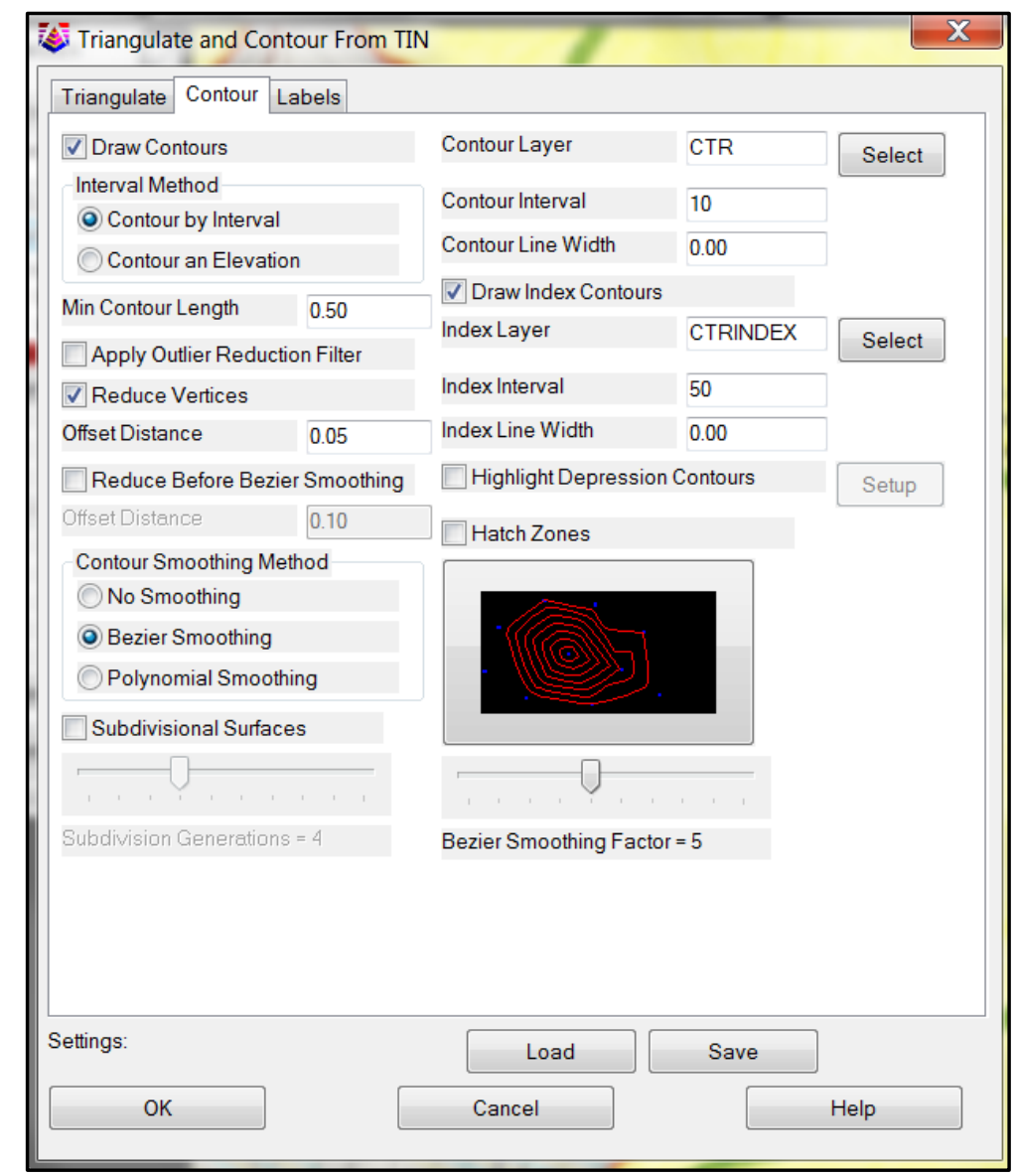

Figure 3.3.5: Contour Options with Selected Options Used with Sample Site

Figure 3.3.6 shows the label options that are available in the triangulate and contour from TIN box. The label options that were used in designing the sample site are also shown (Figure 3.3.36). 


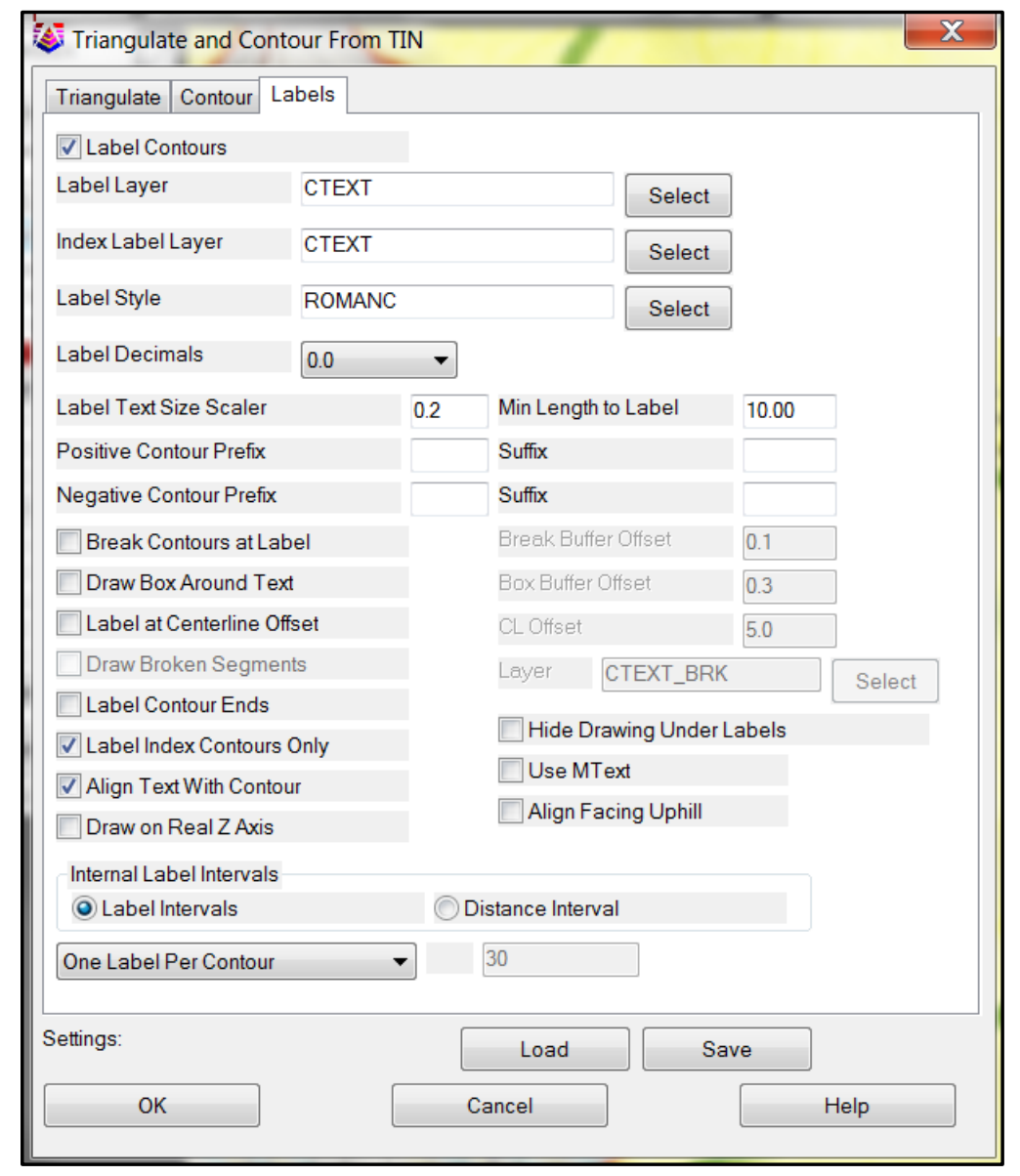

Figure 3.3.6: Label Options with Selected Options Used with Sample Site

After all of the options were chosen by the user, the OK tab was clicked and the program contoured the drawing according to the specifications of the user. Once Natural Regrade ${ }^{\circledR}$ created the contours on the drawing, the DWG tab and the Edit design surface in drawing options were automatically selected. Through the DWG tab, the user could view and edit the 3D surface that was just created. Figure 3.3.7 shows all of the options of viewing and editing the drawing. 


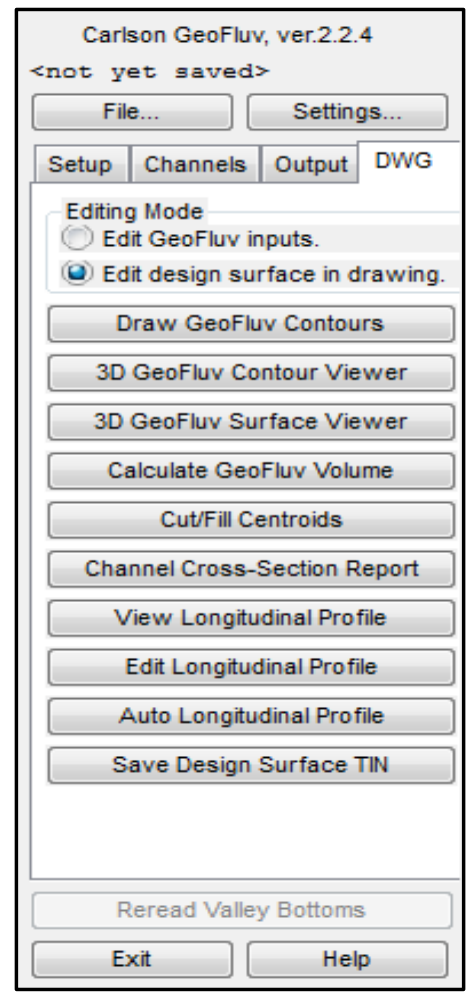

\section{Figure 3.3.7: View and Edit Options for Created Drawing}

\subsection{Sample Site Description}

In the first few months of the project, information was collected, including AutoCAD maps, soil samples, and site specific information. This was achieved by a visit to the sample surface mine in Southern West Virginia. We were taken on a tour of the pre-mined site, currently being mined, and reclaimed areas. Soil samples were taken on the site so that soil testing could be performed and AutoCAD maps of the property were collected in order to make a geomorphic reclamation design. Some pictures of the site visit are shown in Figure 3.4.1. 

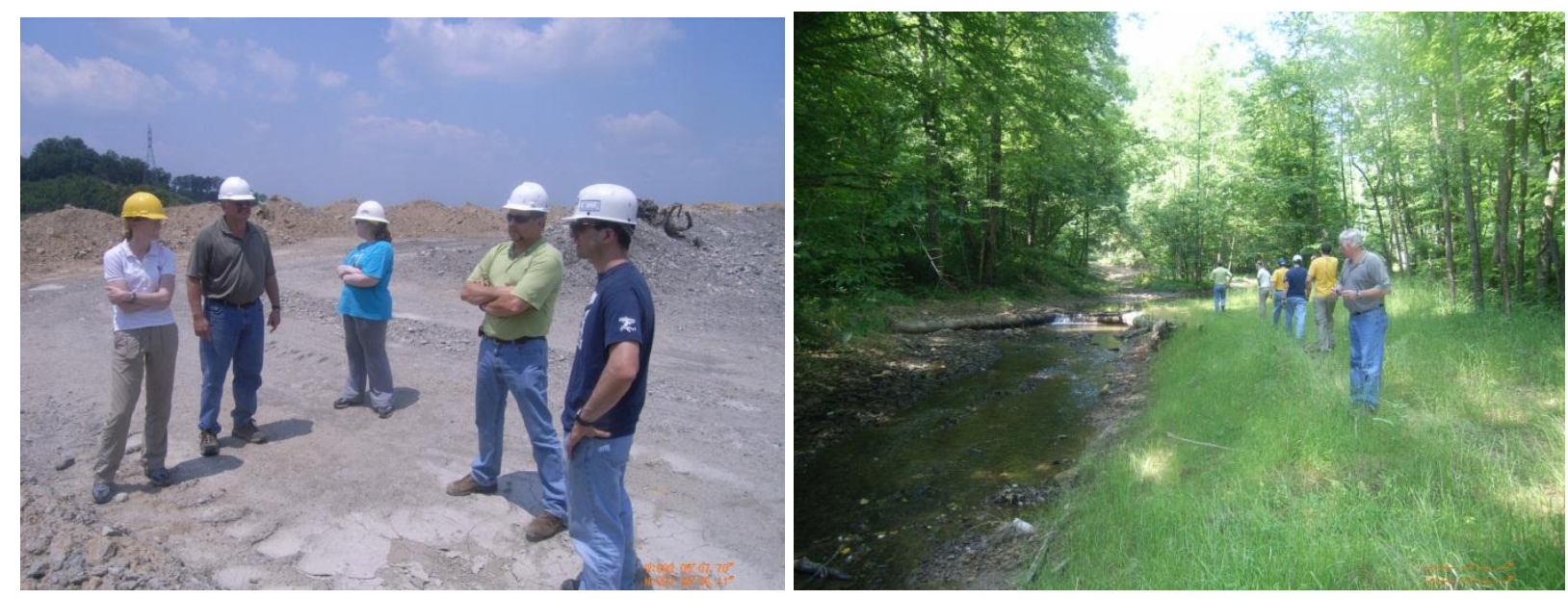

Figure 3.4.1: Sample Surface Mine Site Visit at

a) Area Currently Being Mined and b) Area Previously Reclaimed

Soil testing was performed at West Virginia University on the samples to obtain characteristics of the soils, such as soil classification, hydraulic conductivity, and moisture content which are specific to the sample site. This information was used in the strategic placement of the soil and rock, and was assessed to reduce the distance the material will be hauled. During the mining process, the overburden will be placed in areas where there are ridges in the geomorphic reclamation design so that it will not have to be moved twice, therefore possibly lowering costs. Also, the placement of the soil was analyzed to reduce the amount of future leaching of selenium into groundwater and streams, a concern that has received recent emphasis in the mining industry.

The design tool, Carlson ${ }^{\circledR}$ Natural Regrade ${ }^{\circledR}$ with GeoFluv ${ }^{\mathrm{TM}}$, was used to apply the geomorphic landform design approach to a specific valleyfill study site that is located in the Southern West Virginia coalfield region. The area is characterized by a system of steep-sloped ridges and valleys which is shown in Figure 3.4.2. 
The study site is a mountaintop removal surface mine site located among steep, rugged terrain. Approximately 75 million cubic yards of overburden and coal will be removed during the mining process, thus leaving the site as shown in Figure 3.4.3.

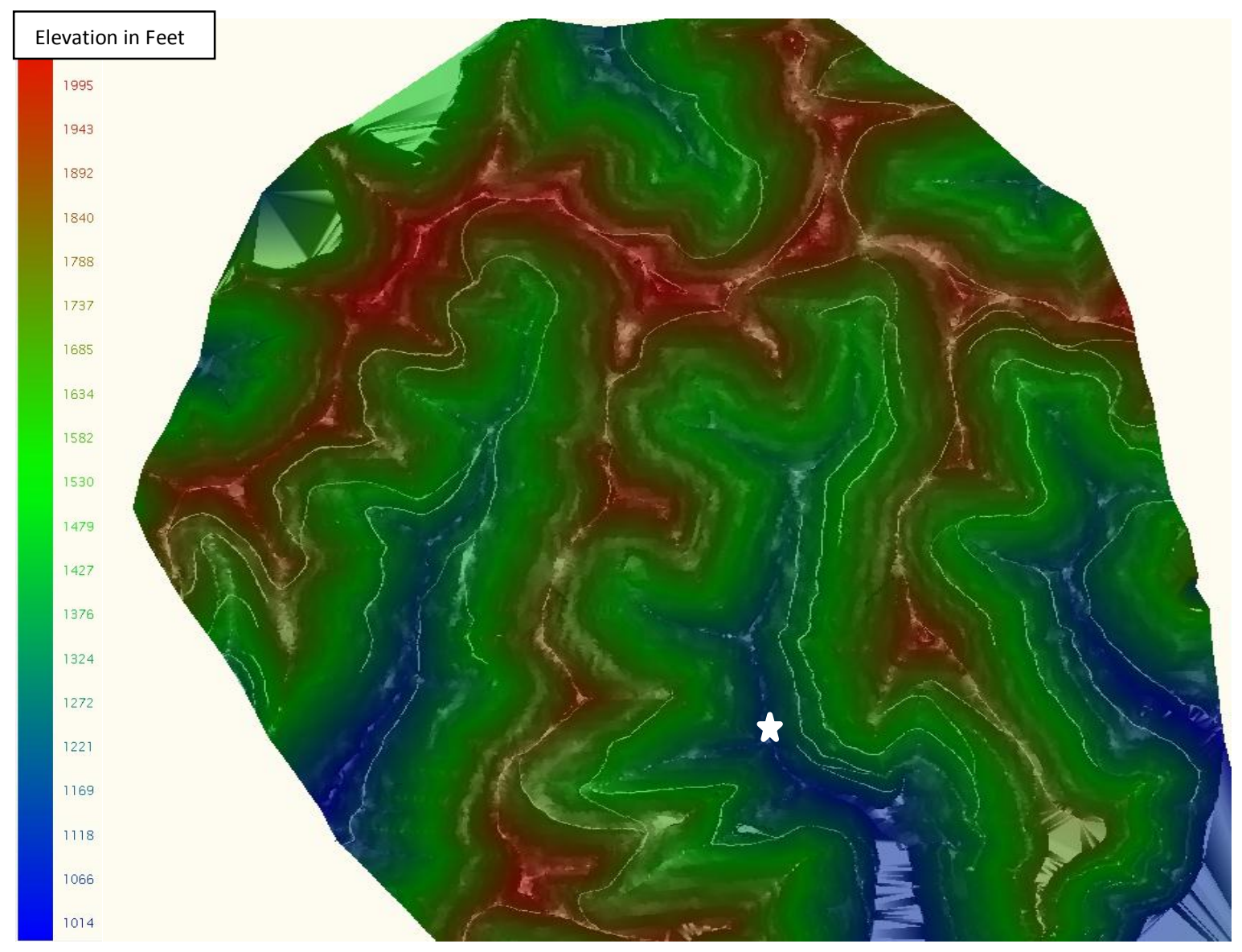

Figure 3.4.2: a) Original Plan View Drawing of Study Area 


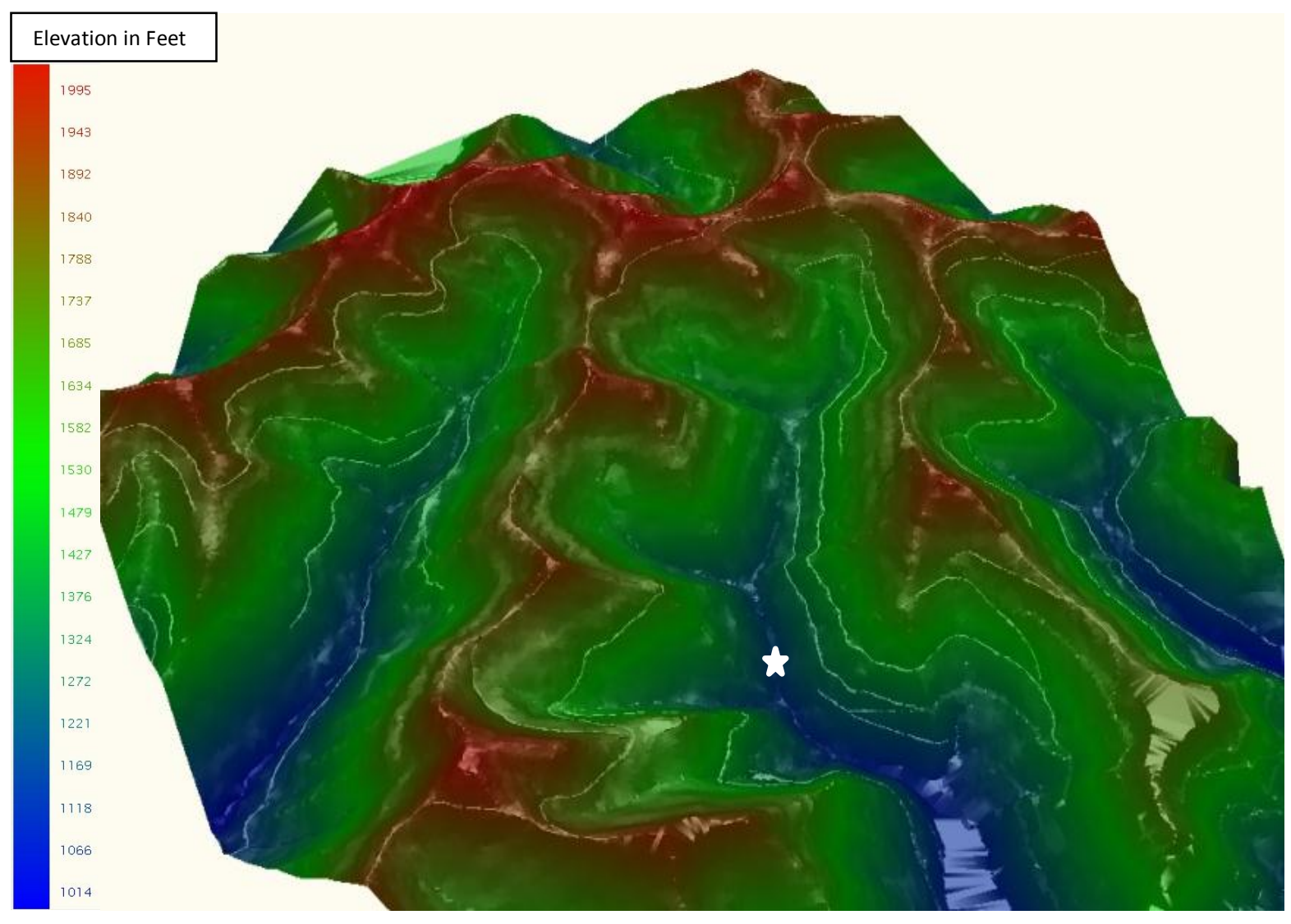

Figure 3.4.2: b) Original Topographic Relief of Study Area 


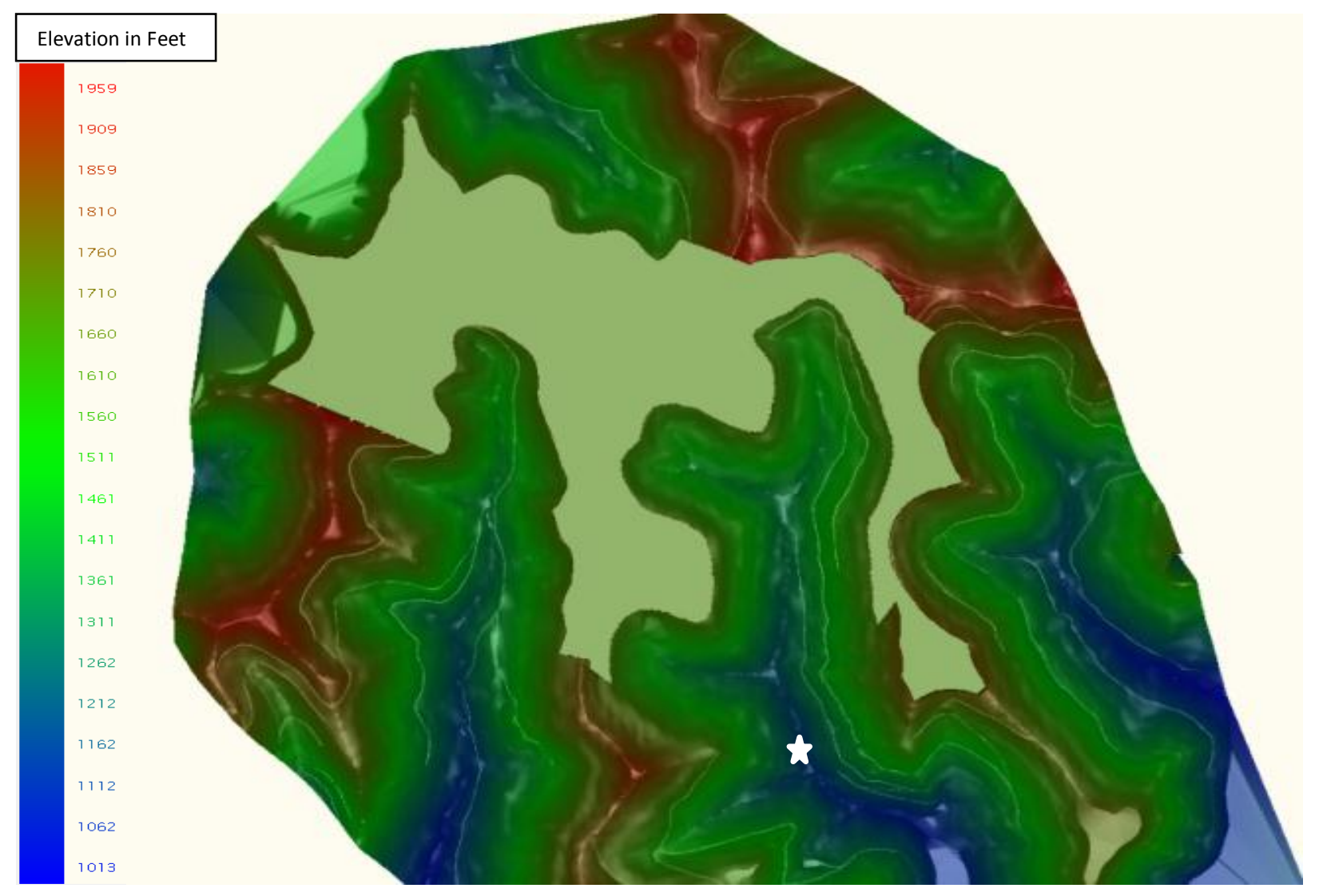

Figure 3.4.3: a) Post-mined Plan View of Study Area 


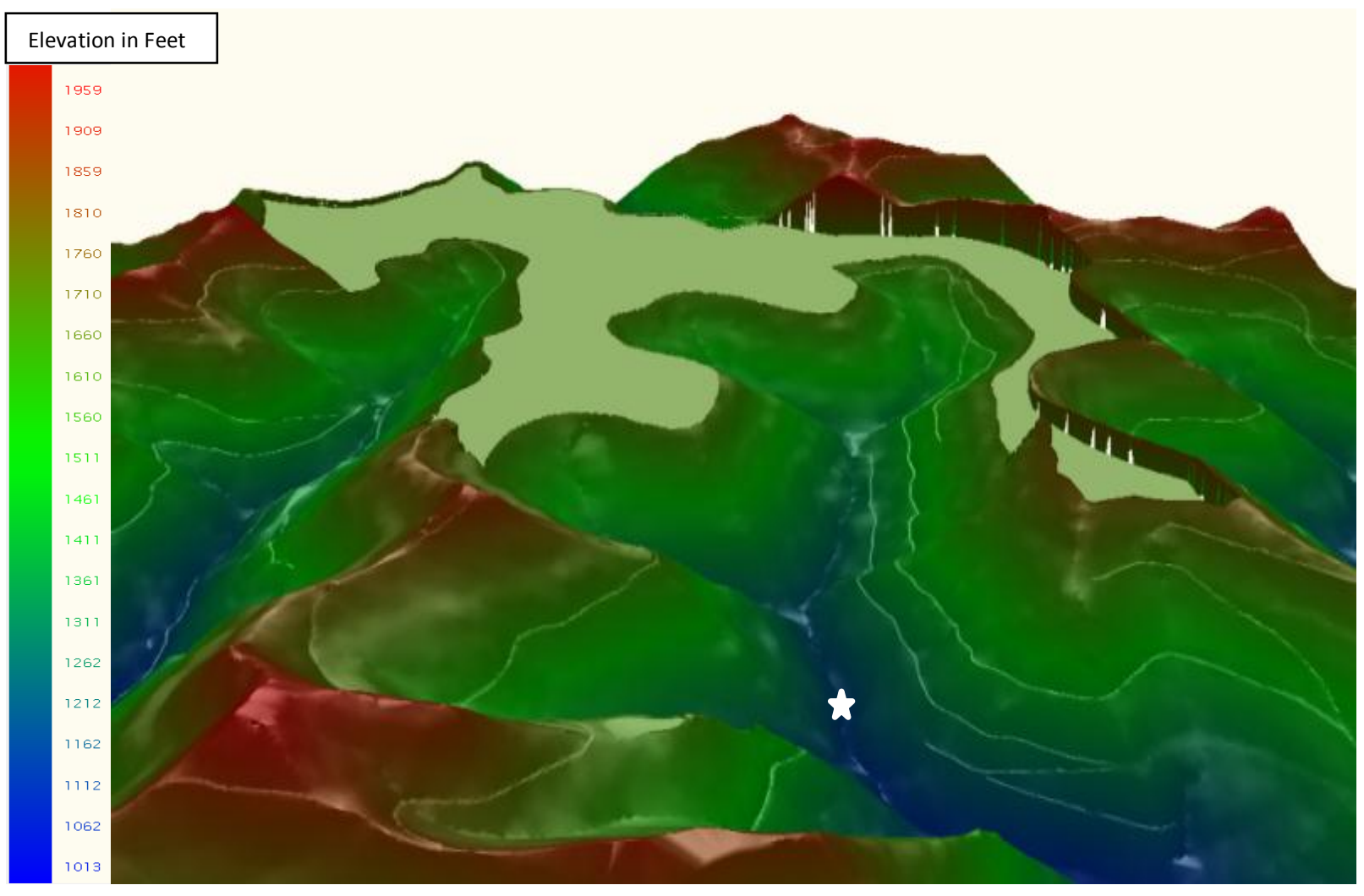

Figure 3.4.3: b) Post-mined Topographic Relief of Study Area 


\section{Data, Results, and Analysis}

\subsection{AOC Variance Valley-fill Design Analysis at Sample Site}

An AOC Variance valley-fill design was being implemented at the sample site in southern West Virginia. The area is characterized by a system of steep-sloped ridges and valleys as previously discussed. The post-mined land use of the area was determined to be pasture land and an AOC variance was obtained in order to leave the land relatively flat at an elevation of approximately $1700 \mathrm{ft}$. The valley fill covered approximately $340 \mathrm{ac}$ and holds over 90 million cubic yards of fill material. Runoff from the property drained to Surface Water Runoff Analysis (SWROA) ditches that outlined the boundary and out National Pollution Discharge and Elimination System (NPDES) points into surrounding stream channels. Figure 4.1.1 shows the post-mined and reclaimed valley fill at the site. 


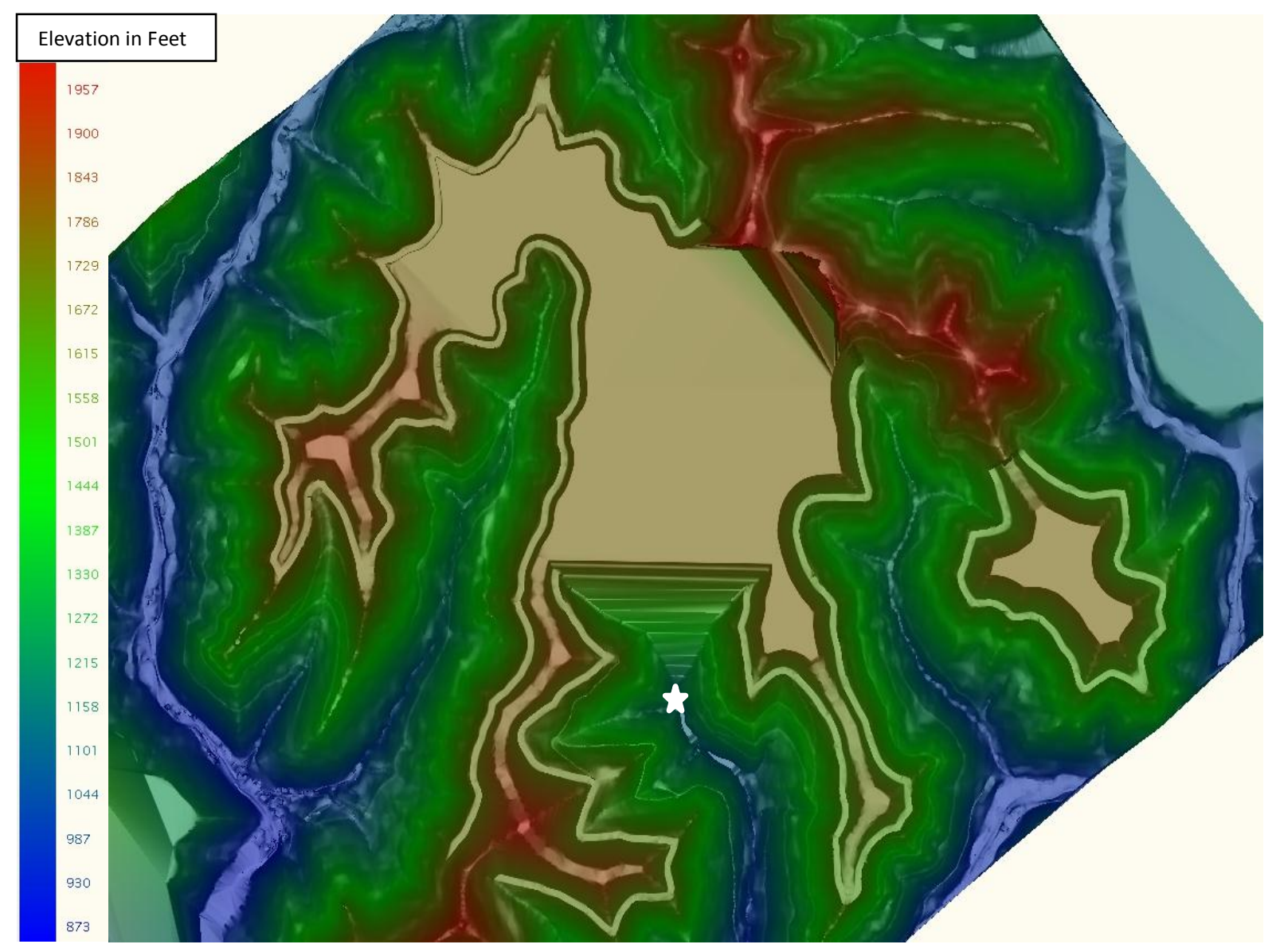

Figure 4.1.1: a) Post-mined "Pastureland" Valley Fill Profile at Sample Site 


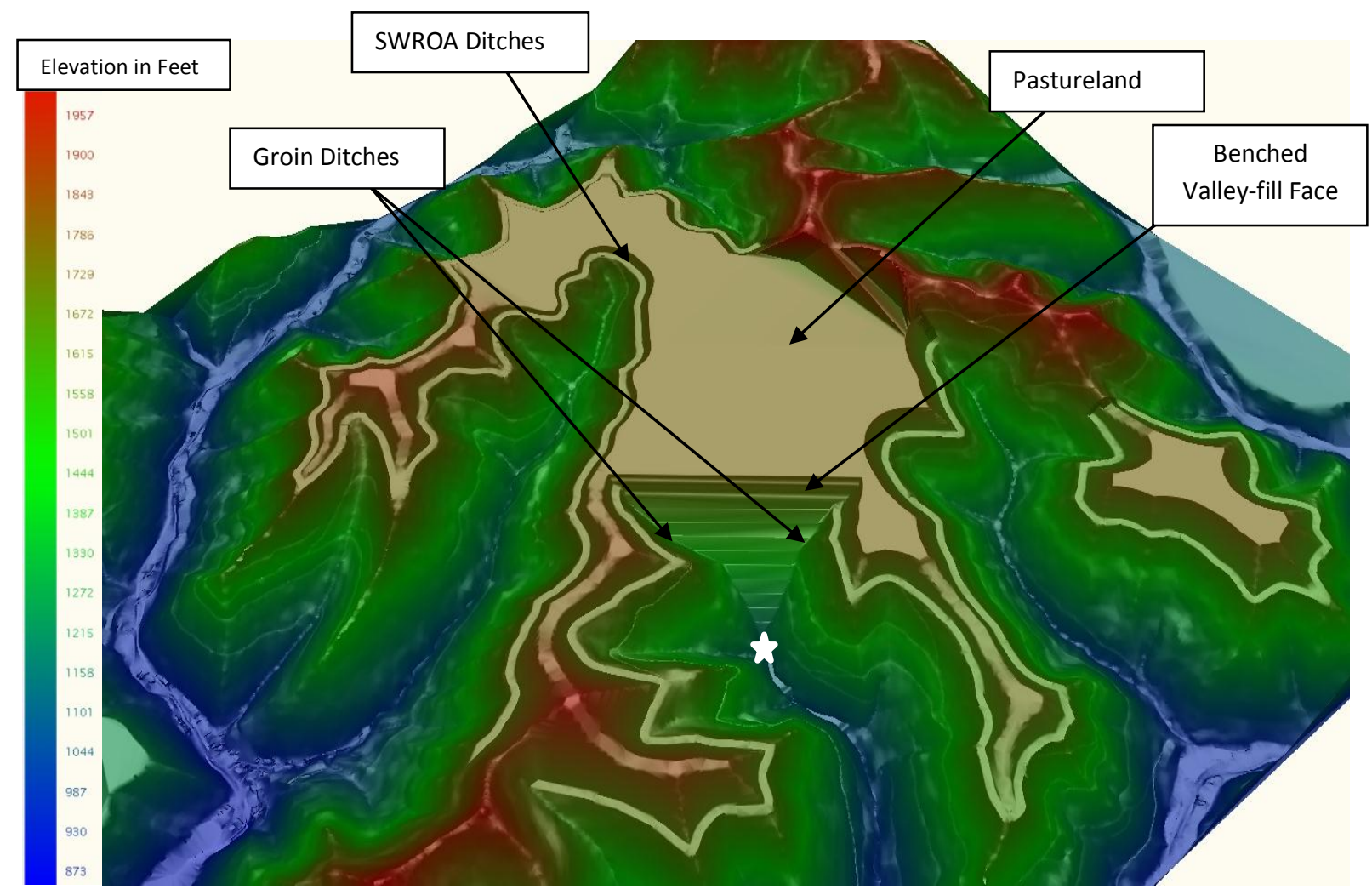

Figure 4.1.1: b) Labeled Features of Post-mined "Pastureland" Valley Fill at Sample Site

The sample site valley-fill design contained numerous features that were typical for many AOC valley-fills designs. These include a traditional rock core underdrain that was formed from the natural segregation of the rock material as it was placed using end-dumping methods as well as a benched valley fill face. The valley fill would be highest in elevation along the top of the benched valley fill area. The fill would then slope down one to two percent toward the north as well as to both sides. Therefore, all drainage would be directed away from the valley-fill face and into the pre-constructed SWROA ditches. This underdrain as well as a cross section of the original topography and the valley fill topography is shown in Figures 4.1.2 and 4.1.3. The face of the valley fill, like many traditional fills, was constructed in benches as to provide stability to the structure. These benches were twenty feet in width and slope back at three to five percent. The benches are constructed every fifty feet in vertical elevation. The layout of the benched valley fill face is shown in Figures 4.1.3 and 4.1.4. 


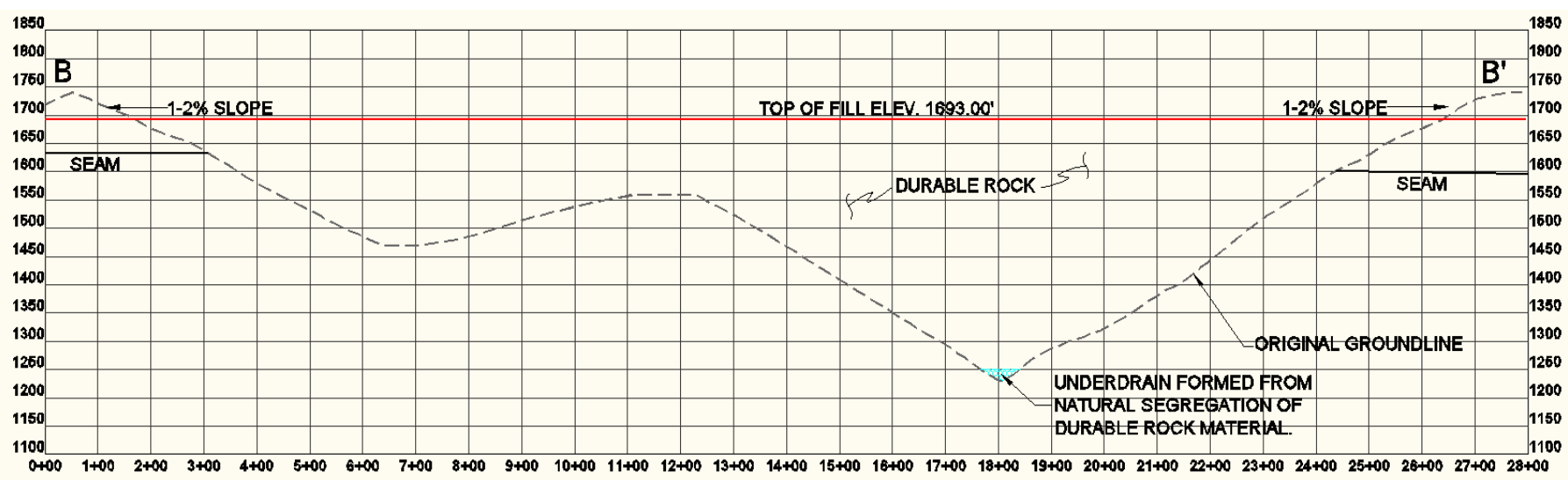

Figure 4.1.2: Sample Site Valley Fill Cross Section (East to West)

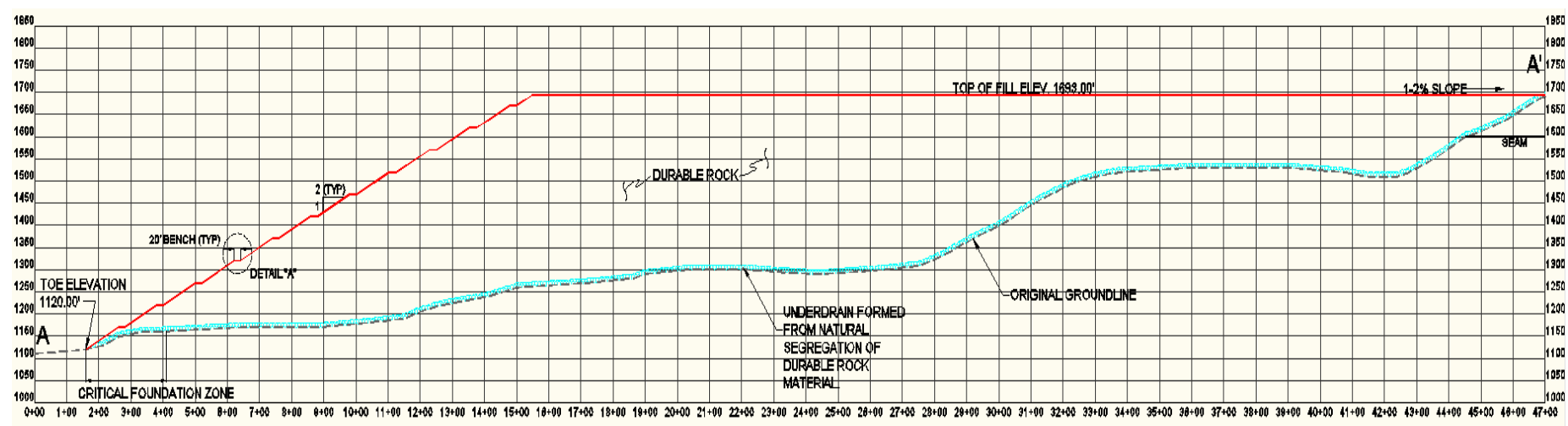

Figure 4.1.3: Sample Site Valley Fill Cross Section (South to North)

Figure 4.1.4: Sample Site Valley Fill Bench Specifications 


\subsection{Natural Regrade ${ }^{\circledR}$ with GeoFluv ${ }^{\mathrm{TM}}$ Design}

The sample site boundary was divided into subwatersheds, as identified in Figure 4.2.1, in order to perform a Natural Regrade ${ }^{\circledR}$ with GeoFluv ${ }^{\mathrm{TM}}$ analysis over the entire disturbed surface mine area. Each subwatershed was designed to drain to existing NPDES permit points to maintain a hydrologic balance. There were a total of six subwatersheds, which ranged in size from just over 4 ac to 241 ac. The geomorphic design principles were then applied to each subwatershed, one at a time, to create balanced, stable landforms.

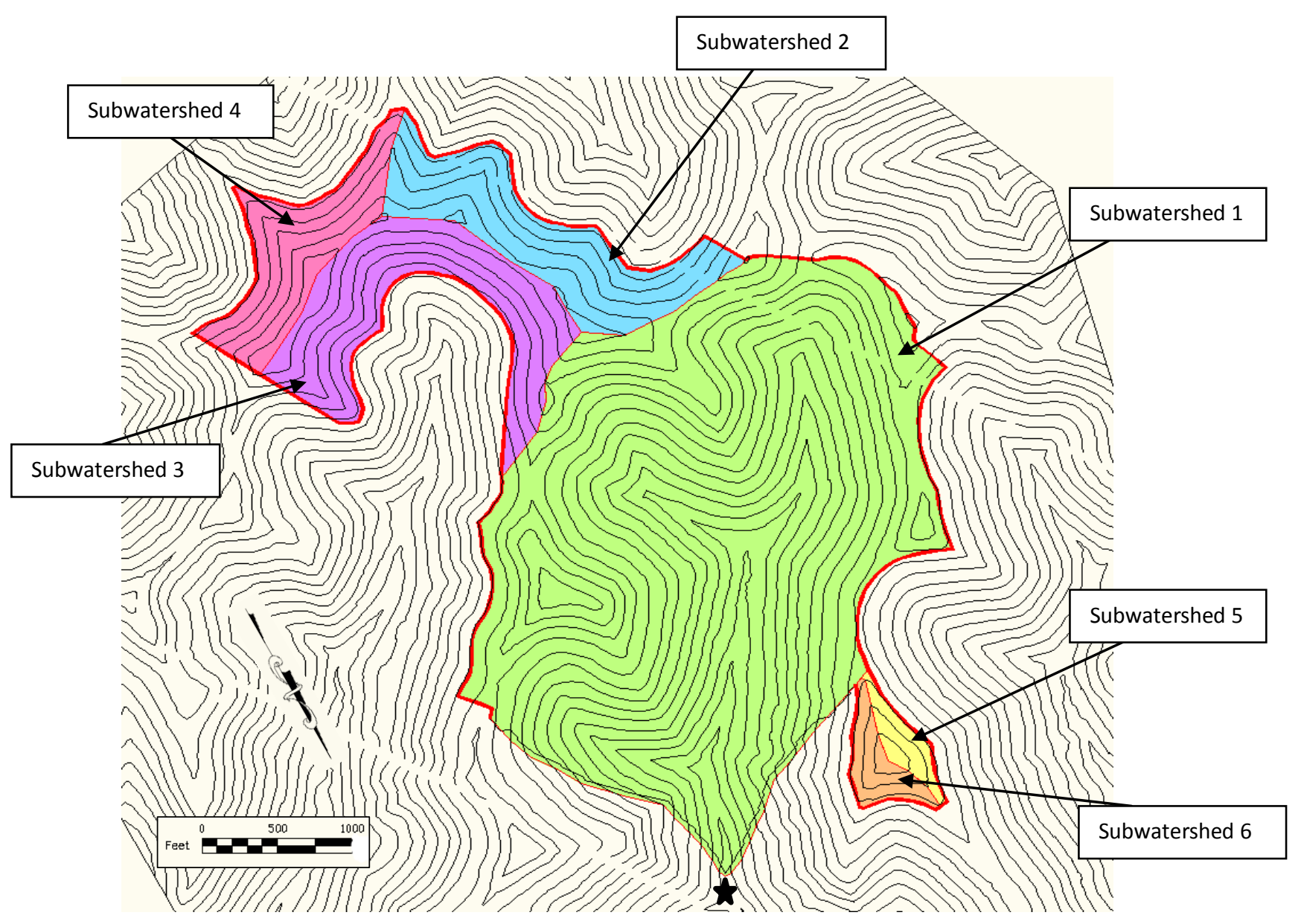

Figure 4.2.1: Subwatersheds Identified in the Valley Fill Study Site 
The subwatershed highlighted in green, as shown in Figure 4.2.2, was analyzed first because it was the largest subwatershed and was located in the center of the sample site property. The subwatershed covered approximately 241 ac and varied in elevation from $1150 \mathrm{ft}$ to $1995 \mathrm{ft}$. It also contained over $8600 \mathrm{ft}$ of original stream length. The original topography of Subwatershed 1 showed a valley running up the center of this property with ridges on the northern, eastern, and western sides. There were also three more subwatersheds located to the north-west side of the property and two more subwatersheds located at the south-east corner of the boundary. These subwatersheds were analyzed later in this section.

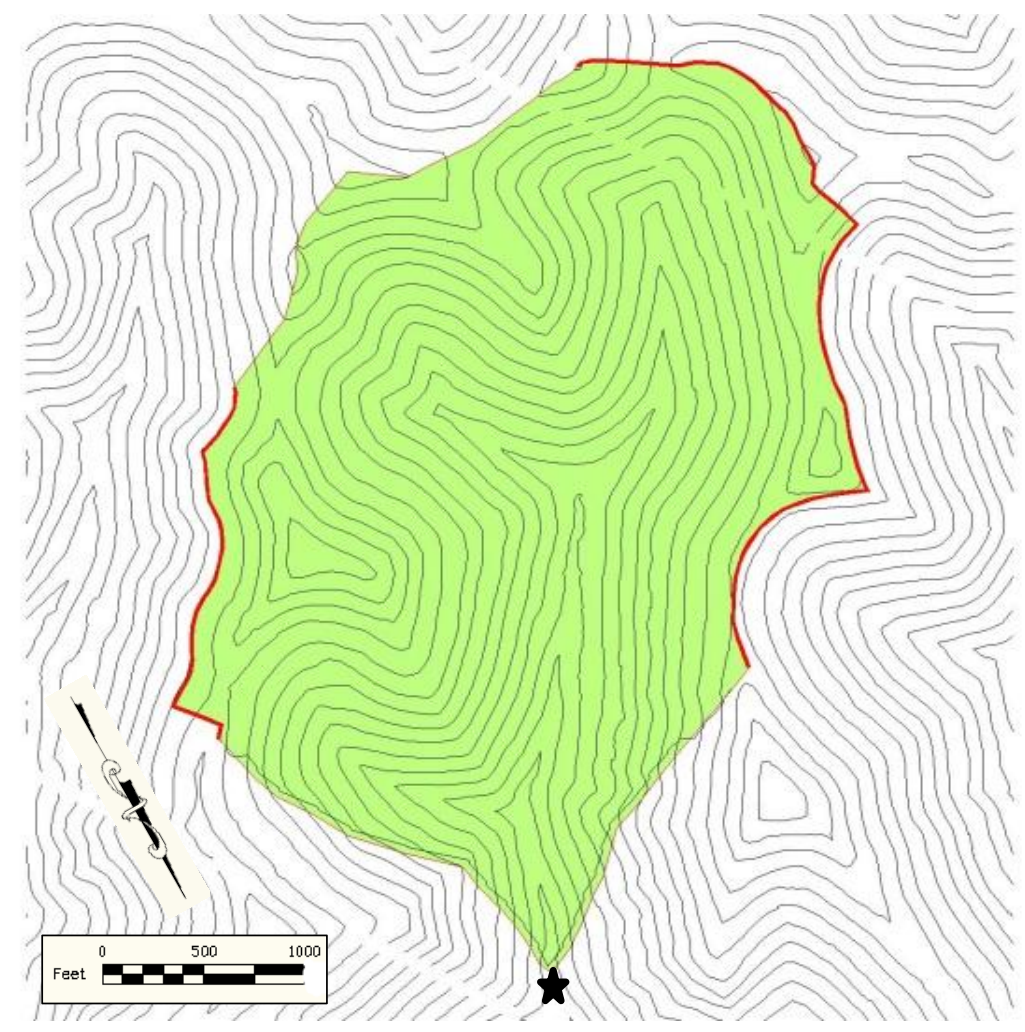

Figure 4.2.2: First and Largest Subwatershed Analyzed: "Subwatershed 1"

Figure 4.2.3 shows the stream channels created for the geomorphic design in the area associated with Subwatershed 1. The design was characterized by a main channel with twelve tributaries, forming a dendritic drainage pattern, which is typical for unconsolidated materials 
(Toy and Chuse, 2005; Eckels and Bugosh, 2010). The created channel pattern mimicked the original drainage pattern of the pre-mined site, but included many more channels. Therefore, the valley fill created using Natural Regrade ${ }^{\circledR}$ had a greater amount of stream length within the same area compared to the original stream length (Table 6.0.1). More tributary channels were added to the main channel closer to its mouth in order to satisfy the target drainage density, while less tributary channels were added at the head of the main channel to meet the drainage density requirement.

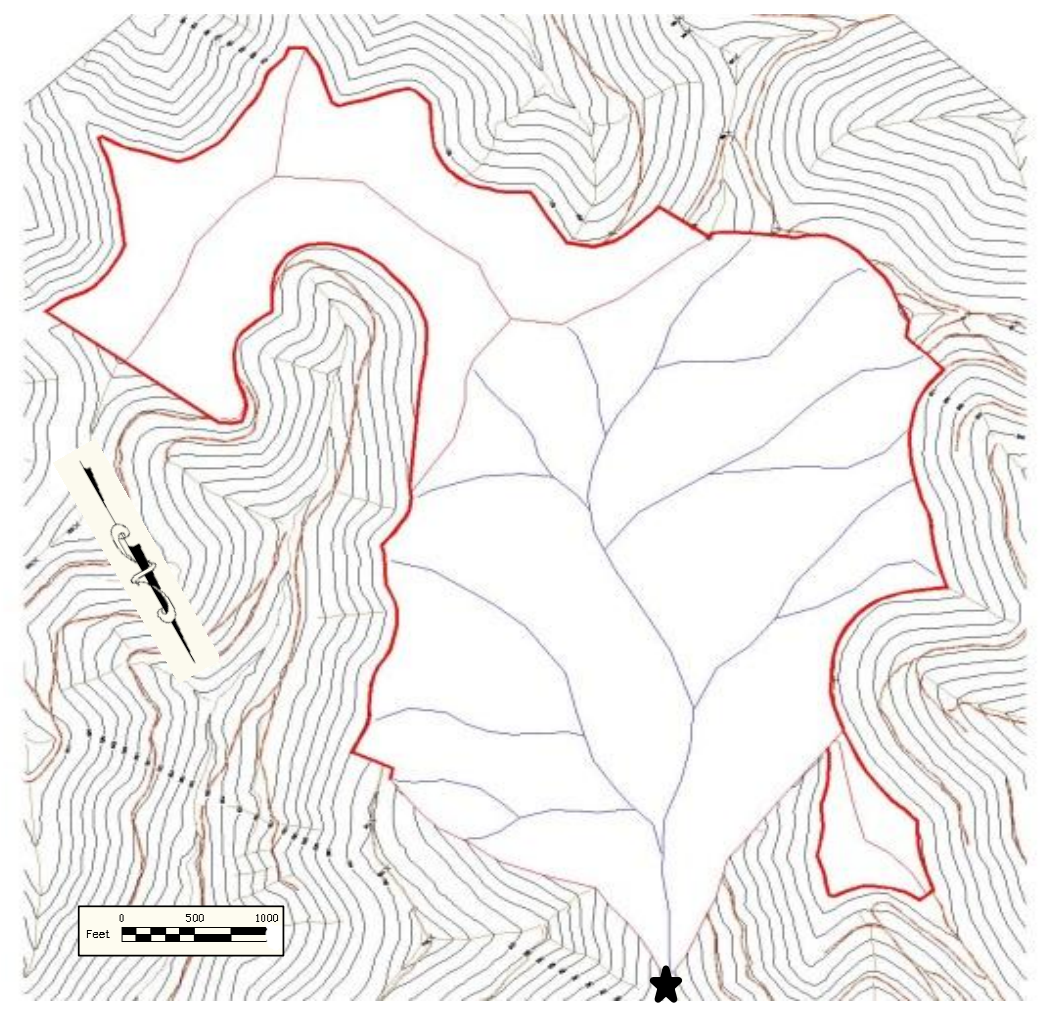

Figure 4.2.3: Streams Created in Subwatershed 1

A close-up view of the created drainage channels within Subwatershed 1 is shown in Figure 4.2.4. The main channel and the twelve tributary channels were labeled, according to their position with respect to the main channel. The channels ranged in length from $814 \mathrm{ft}$ to almost 5,300 ft. The dendritic pattern of the channels matched the pattern of channels in 
watersheds surrounding the sample site property boundary. This was incredibly important due to one of the established goals to have the created valley fill blend in with the surroundings.

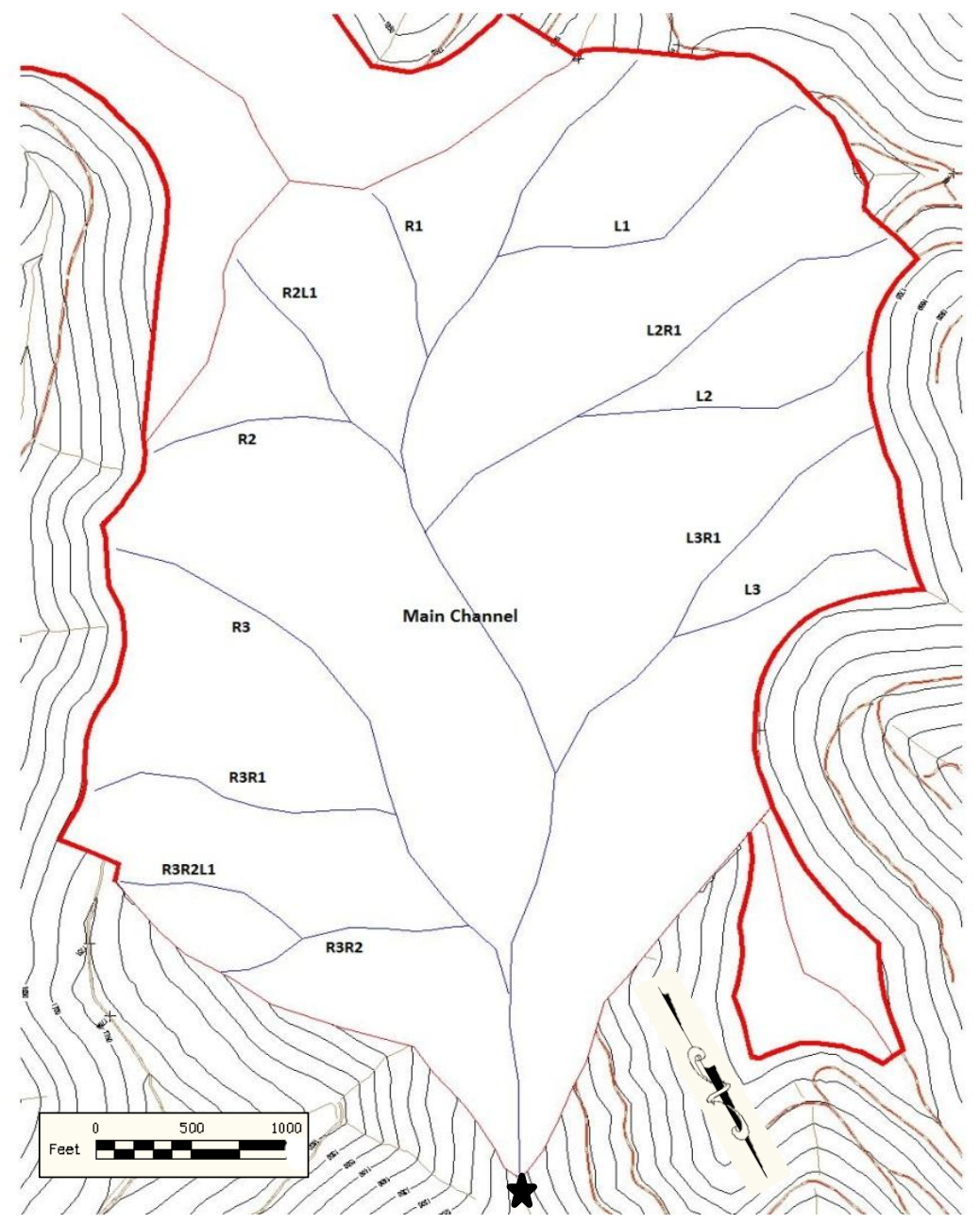

Figure 4.2.4: Subwatershed 1 with Labeled Created Streams

Geomorphic landform design principles using Natural Regrade ${ }^{\circledR}$ with GeoFluv ${ }^{\mathrm{TM}}$ were applied to Subwatershed 1 after all of the channels were created and the drainage density was checked to be within the targeted area. The step-by-step method that was explained in the "Method: Step-by-Step Procedure and Method for Design" section was applied to this subwatershed, thus creating an aesthetically pleasing valley fill that appeared natural with ridges and valleys. The geomorphic landform design also required fewer artificial elements and supported long-term stability due to the mature landforms that were created (Martin-Duque et al., 
2009). This also led to reduced maintenance and cost because of decreased erosion of the landforms. The created stream channels help control drainage on the property through the channelization of groundwater flow or precipitation.
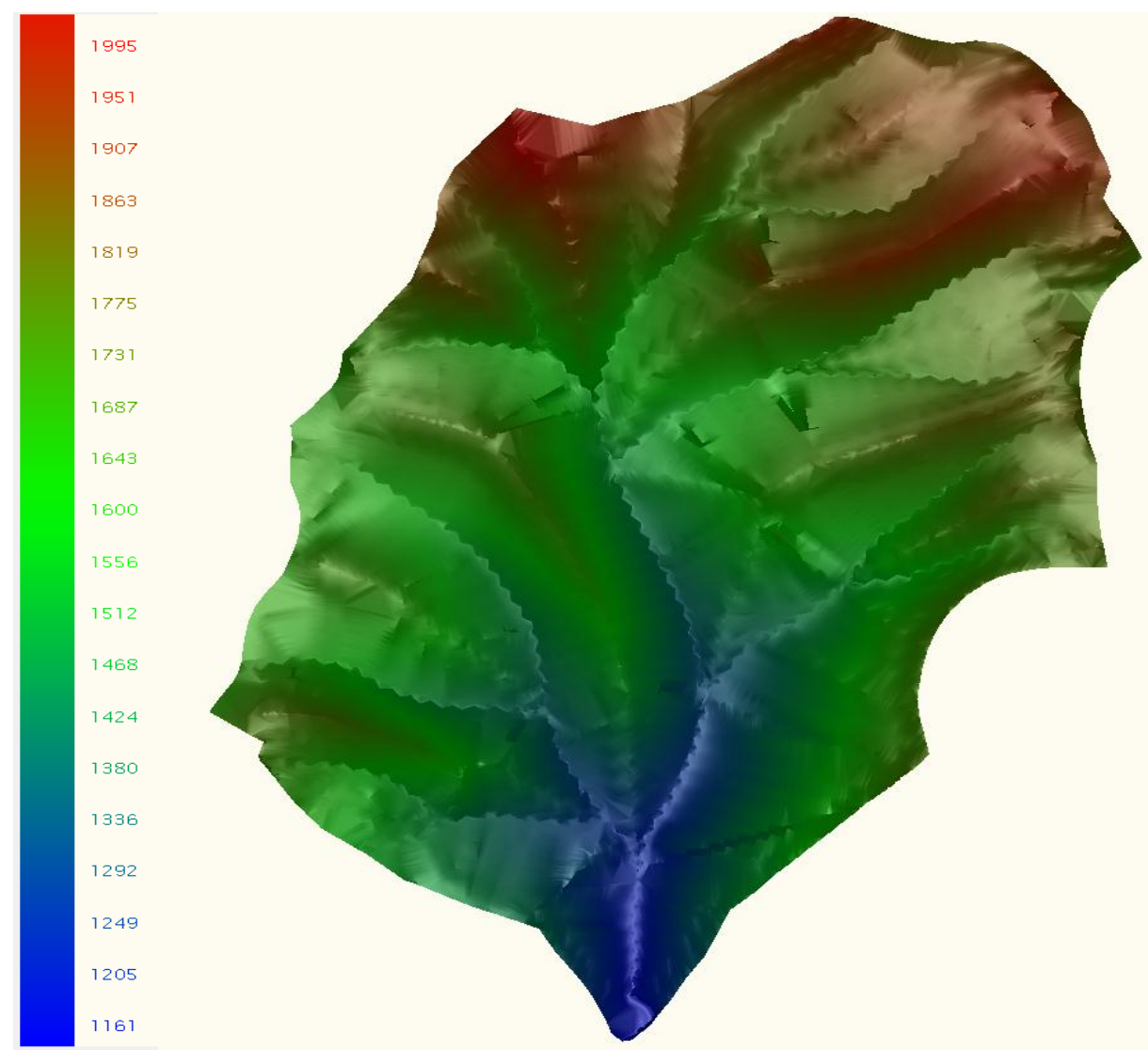

Figure 4.2.5: Completed Subwatershed 1 Geomorphic Valley-fill Design

There is a large amount of information obtained from the created geomorphic landform reclamation design. This wide range of data is shown in Tables 4.2.1 through 4.2.4. The watershed area that supplied each stream channel as well as the overall total watershed area, which is 241 ac for Subwatershed 1, was one of the important data that is obtained. The overall resulting drainage density for Subwatershed 1 was $90.62 \mathrm{ft} / \mathrm{ac}$ (Table 4.2.4), which was within the target range of 80-120 ft/ac. Additionally, the drainage density of each channel was within the targeted range as to create a balanced design. The design included a total of 21,900 ft or over 
four miles of channel length, including type A and type C channels as defined by Rosgen (1994).

Also, this geomorphic valley-fill design enabled $1300 \mathrm{ft}$ of original stream length to remain

undisturbed compared to the traditional valley-fill design (Table 6.0.1). Additional design

specifications are outlined in Tables 4.2.1-4.2.4.

Table 4.2.1: Channel Data for Subwatershed 1 Channels Main, R3, R3R2 and R3R2L1

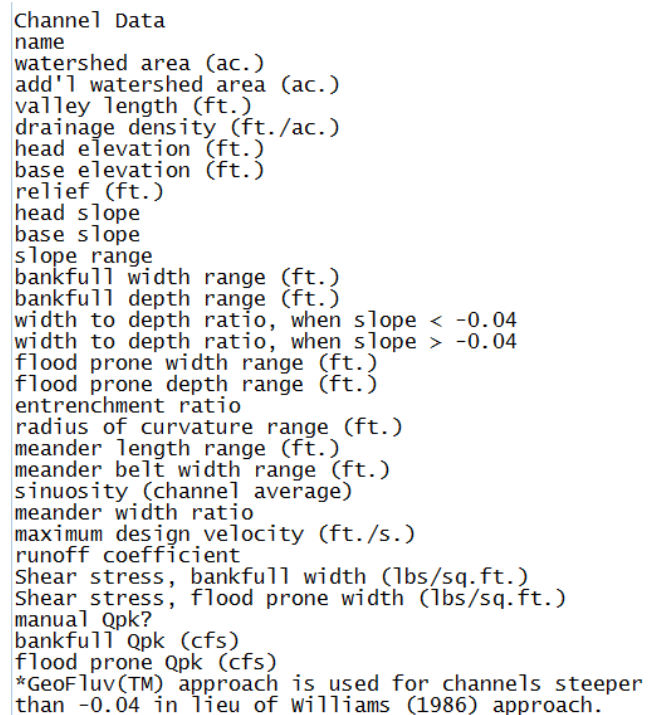

main
241.14
0.00
5225.67
90.62
1848.73
1131.85
716.89
-0.12
-0.06
-0.120 to -0.056
0.36 to 18.93
0.04 to 1.51
12.50
10.00
0.76 to 39.69
0.08 to 4.50
2.10 to 2.32
1.37 to 58.99
6.21 to 266.86
2.92 to 125.60
1.15
6.34
4.50
0.89
0.17 to 14.16
0.27 to 20.30
no
129.84
432.81

R3
63.95
0.00
2622.37
90.22
1668.39
1238.35
430.04
-0.15
-0.12
-0.149 to -0.120
0.45 to 8.75
0.05 to 0.87
12.50
10.00
1.05 to 20.28
0.12 to 2.32
2.32
n/a*
n/a*
n/a*
1.14
n/a*
4.50
0.89
0.47 to 7.87
0.67 to 11.28
no
34.43
114.78

R3R2
17.25
0.00
1052.94
108.33
1549.83
1287.83
261.99
-0.22
-0.15
-0.221 to -0.151
0.35 to 4.54
0.03 to 0.45
12.50
10.00
0.80 to 10.53
0.09 to 1.20
2.32
n/a*
n/a*
n/a*
1.15
n/a*
4.50
0.89
0.54 to 6.62
0.77 to 9.49
no
9.29
30.96

R3R2L1
6.89
0.00
815.68
118.44
1693.06
1458.08
234.98
-0.26
-0.22
-0.258 to -0.222
0.17 to 2.87
0.02 to 0.29
12.50
10.00
0.39 to 6.65
0.04 to 0.76
2.32
n/a*
n/a*
n/a*
1.15
n/a*
4.50
0.89
0.30 to 4.46
0.43 to 6.39
no
3.71
12.36

\section{Table 4.2.2: Channel Data for Subwatershed 1 Channels R3R1, L3, L3R1 and L2}

Channe1 Data
name
watershed area (ac.)
add'1 watershed area (ac.)
valley length (ft.)
drainage density (ft. /ac.)
head elevation (ft.)
base elevation (ft.)
relief (ft.)
head slope
base slope
slope range
bankful1 width range (ft.)
bankfu11 depth range (ft.)
width to depth ratio, when slope < -0.04
width to depth ratio, when slope > -0.04
flood prone width range (ft.)
flood prone depth range (ft.)
entrenchment ratio
radius of curvature range (ft.)
meander length range (ft.)
meander belt width range (ft.)
sinuosity (channe1 average)
meander width ratio
maximum design velocity (ft./s.)
runoff coefficient
Shear stress, bankful1 width (lbs/sq.ft.)
Shear stress, flood prone width (lbs/sq. ft.)
manual Qpk?
bankful1 Qpk (cfs)
flood prone Qpk (cfs)
*Geofluv(TM) approach is used for channels steeper
than -0.04 in lieu of williams (1986) approach.

R3R1
15.57
0.00
1278.59
82.11
1673.72
1381.33
292.38
-0.21
-0.15
-0.205 to -0.150
0.52 to 4.32
0.05 to 0.43
12.50
10.00
1.21 to 10.01
0.14 to 1.14
2.32
n/a*
n/a*
n/a*
1.14
n/a*
4.50
0.89
0.75 to 5.61
1.07 to 8.05
no
8.38
27.95

L3
34.02
0.00
1838.51
90.35
1768.39
1369.81
398.58
-0.19
-0.13
-0.193 to -0.126
0.42 to 6.38
0.04 to 0.64
12.50
10.00
0.97 to 14.79
0.11 to 1.69
2.32
n/a*
n/a*
n/a*
1.15
n/a*
4.50
0.89
0.57 to 8.15
0.81 to 11.68
no
18.32
61.06

L2
35.95
0.00
2046.70
98.67
1811.93
1529.90
282.04
-0.12
-0.12
-0.120 to -0.120
0.25 to 6.56
0.03 to 0.66
12.50
10.00
0.59 to 15.20
0.07 to 1.74
2.32
n/a*
n/a*
n/a*
1.15
n/a*
4.50
0.89
0.21 to 5.50
0.30 to 7.88
no
19.36
64.52


Table 4.2.3: Channel Data for Subwatershed 1 Channels L2R1, R2, R2L1 and R1

Channe1 Data
name
watershed area (ac.)
add'1 watershed area (ac.)
valley length (ft.)
drainage density (ft. /ac.)
head elevation (ft.)
base elevation (ft.)
relief (ft.)
head slope
base slope
slope range
bankful1 width range (ft.)
bankful1 depth range (ft.)
width to depth ratio, when slope < -0.04
width to depth ratio, when slope > -0.04
flood prone width range (ft.)
flood prone depth range (ft.)
entrenchment ratio
radius of curvature range (ft.)
meander length range (ft.)
meander belt width range (ft.)
sinuosity (channe1 average)
meander width ratio
maximum design velocity (ft./s.)
runoff coefficient
Shear stress, bankful1 width (lbs/sq.ft.)
Shear stress, flood prone width (lbs/sq.ft.)
manual Qpk?
bankful1 Qpk (cfs)
flood prone Qpk (cfs)
*Geofluv(TM) approach is used for channels steeper
than -0.04 in lieu of williams (1986) approach.
than

L2R 1
15.15
0.00
1500.47
99.02
1845.96
1642.16
203.79
-0.12
-0.12
-0.120 to -0.120
0.53 to 4.26
0.05 to 0.43
12.50
10.00
1.23 to 9.87
0.14 to 1.13
2.32
n/a*
n/a*
n/a*
1.13
n/a*
4.50
0.89
0.44 to 3.57
0.64 to 5.12
no
8.16
27.20

R2
19.70
0.00
1133.25
100.33
1722.94
1566.76
156.18
-0.12
-0.12
-0.120 to -0.120
0.20 to 4.86
0.02 to 0.49
12.50
10.00
0.47 to 11.25
0.05 to 1.29
2.32
n/a*
n/a*
n/a*
1.15
n/a*
4.50
0.89
0.17 to 4.07
0.24 to 5.84
no
10.61
35.36

R2L1
8.50
0.00
843.29
99.25
1852.72
1609.84
242.88
-0.26
-0.17
-0.259 to -0.168
0.46 to 3.19
0.05 to 0.32
12.50
10.00
1.06 to 7.39
0.12 to 0.84
2.32
n/a*
n/a*
n/a*
1.13
n/a*
4.50
0.89
0.83 to 5.34
1.18 to 7.65
no
4.58
15.25

R1
8.11
0.00
745.47
91.96
1932.69
1636.83
295.85
-0.35
-0.26
-0.352 to -0.263
0.32 to 3.11
0.03 to 0.31
12.50
10.00
0.74 to 7.22
0.09 to 0.82
2.32
n/a*
n/a*
n/a*
1.14
n/a*
4.50
0.89 to 7.13
0.79 to
1.13 to 10.22
no
4.37
14.55

Table 4.2.4: Channel Data for Subwatershed 1 Channel L1 and Total Summary Data

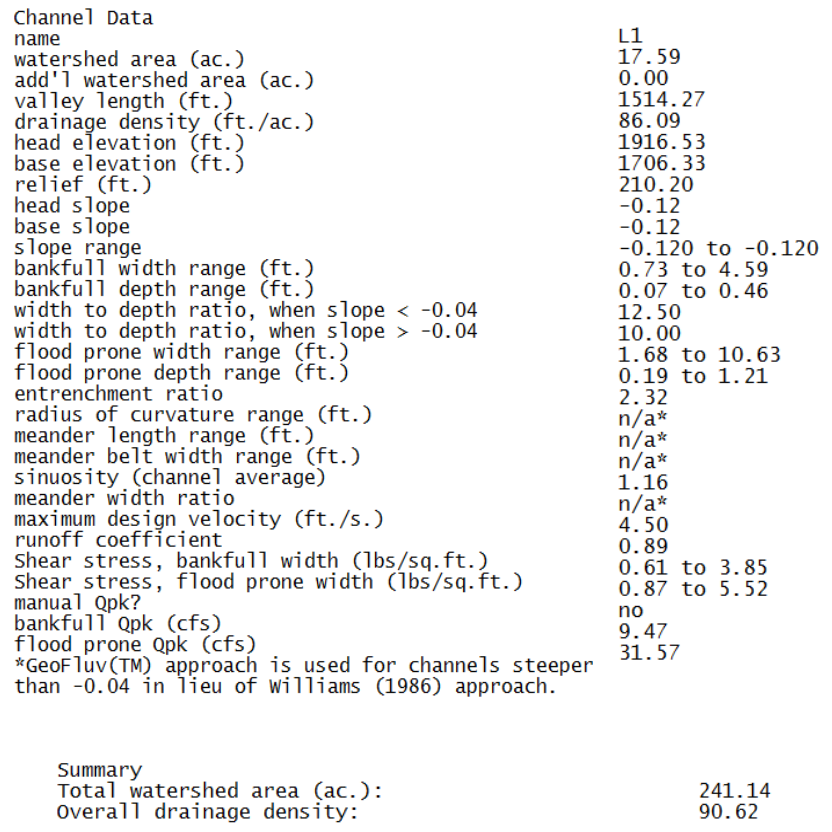

Subwatershed 2, highlighted in blue in Figure 4.2.6, was analyzed second because it was located adjacent to Subwatershed 1 valley fill that was previously created. The Subwatershed 2 
analysis used the original topography as well as the created Subwatershed 1 topography so that the created landforms would merge smoothly. The subwatershed covered approximately 32 ac and varied in elevation from $1720 \mathrm{ft}$ to $1995 \mathrm{ft}$. It also contained over $1180 \mathrm{ft}$ of original stream length. The original topography of Subwatershed 2 showed a ridge running along the southern side of this property and sloped down toward the northern side. The subwatershed connected to the previously created Subwatershed 1 along the eastern side and bordered two other subwatersheds located along the southern and western sides of the property. These subwatersheds were analyzed later in this section.

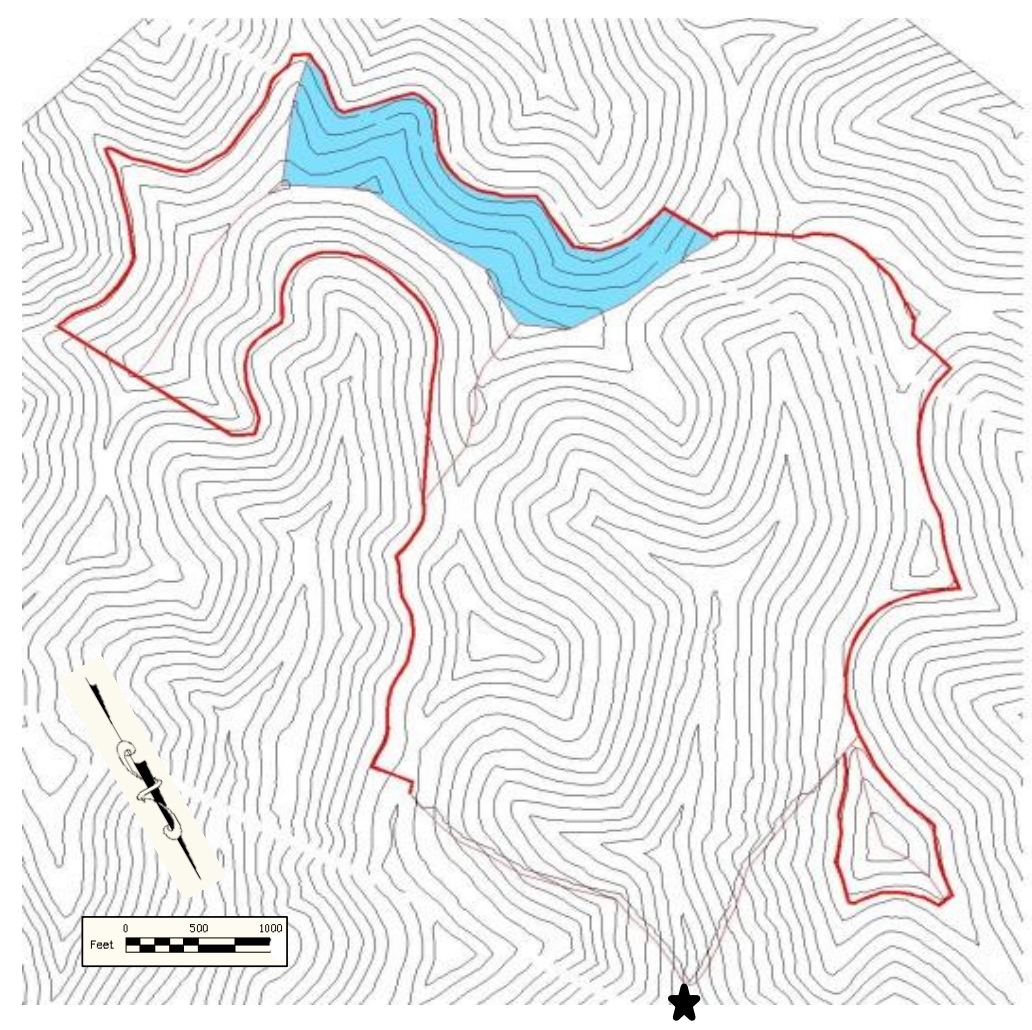

Figure 4.2.6: Second Subwatershed Analyzed: "Subwatershed 2"

Figure 4.2.7 shows the stream channel created for the geomorphic design in the area associated with Subwatershed 2. The design was characterized by a single main channel that flowed through the property. Only one channel was needed to satisfy the drainage density 
requirement due to the watershed area and the length of the main channel. Even though only one channel was created, the valley fill created using Natural Regrade ${ }^{\circledR}$ still had a greater amount of stream length within the same area compared to the original stream length (Table 6.0.1).

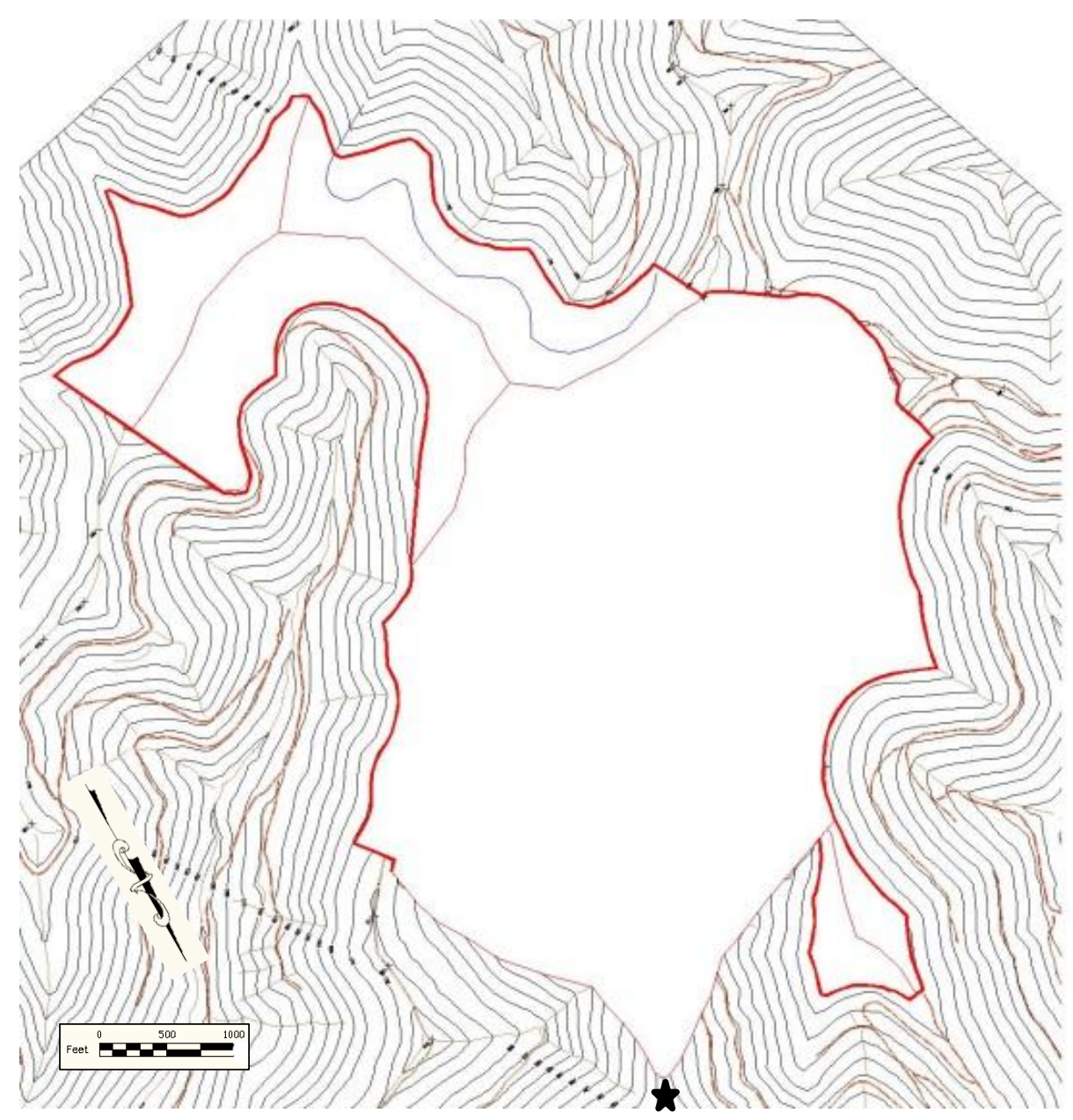

Figure 4.2.7: Streams Created in Subwatershed 2

Figure 4.2.8 shows a close-up view of the created drainage channel within Subwatershed 2. The main channel was labeled "Main" and was approximately $3500 \mathrm{ft}$ long. 


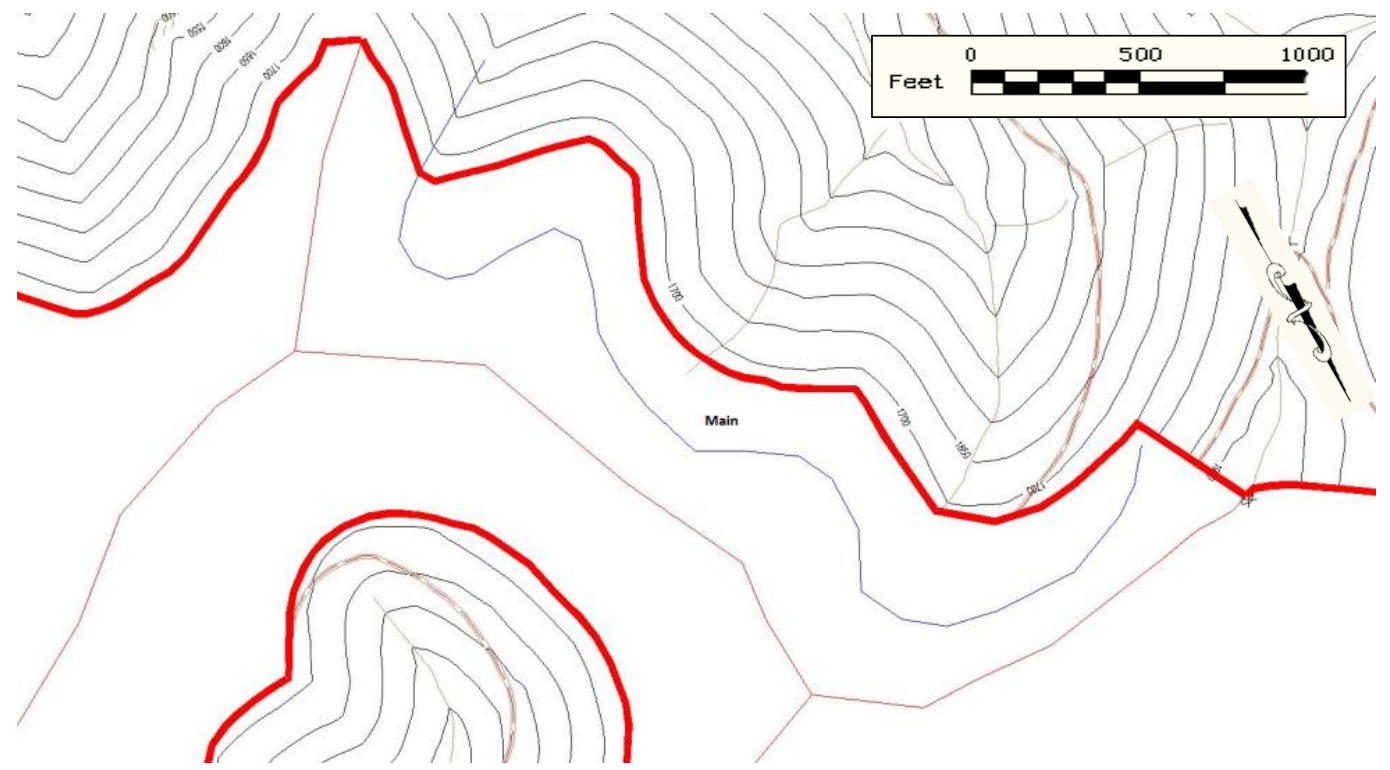

Figure 4.2.8: Subwatershed 2 with Labeled Created Stream

The same geomorphic landform design principles that were applied to the Subwatershed 1 were applied to Subwatershed 2 and the following subwatersheds. Next, the drainage density was verified to be within the targeted range of 80-120 ft/ac. Also, the "Method: Step-by-Step Procedure and Method for Design" procedure was applied to this subwatershed and the following subwatersheds, thus creating valley fills that had the same qualities and advantages such as long-term stability, minimal erosion, and groundwater channelization as Subwatershed 1. 


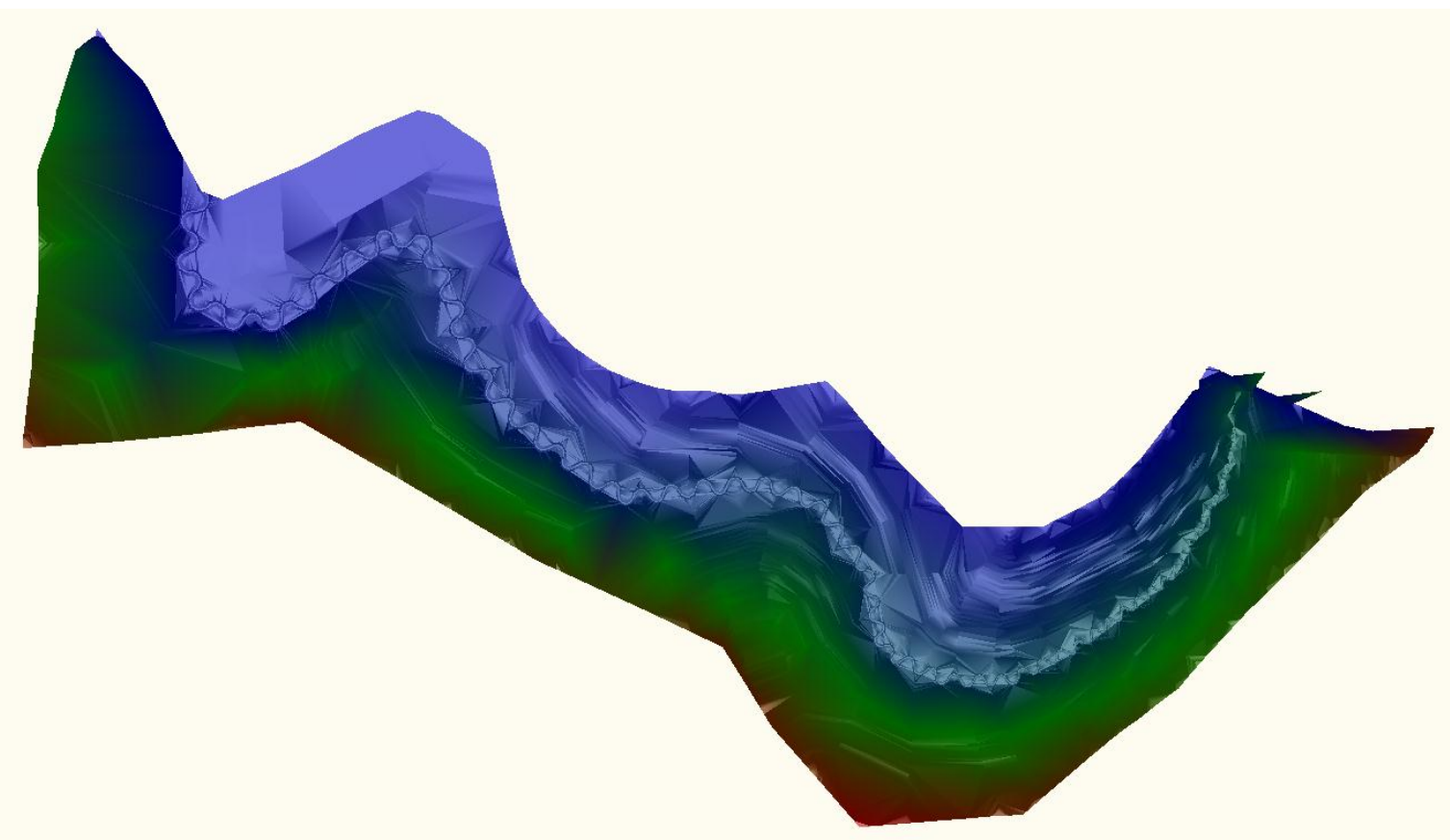

Figure 4.2.9: Completed Subwatershed 2 Geomorphic Valley-fill Design

A large amount of data was obtained from the created Subwatershed 2 geomorphic landform reclamation design. This wide range of data is shown below in Table 4.2.5. The watershed area that supplied the stream channel was 31.8 ac for the second subwatershed, which was one of the important information obtained. The overall resulting drainage density for the blue subwatershed was $99.35 \mathrm{ft} / \mathrm{ac}$ (Table 4.2.5). The design added a total of $3500 \mathrm{ft}$ or two thirds of a mile of channel length (Table 6.0.1), including type A and type $\mathrm{C}$ channels. 


\section{Table 4.2.5: Channel Data for Subwatershed 2 Channel Main and Total Summary Data}

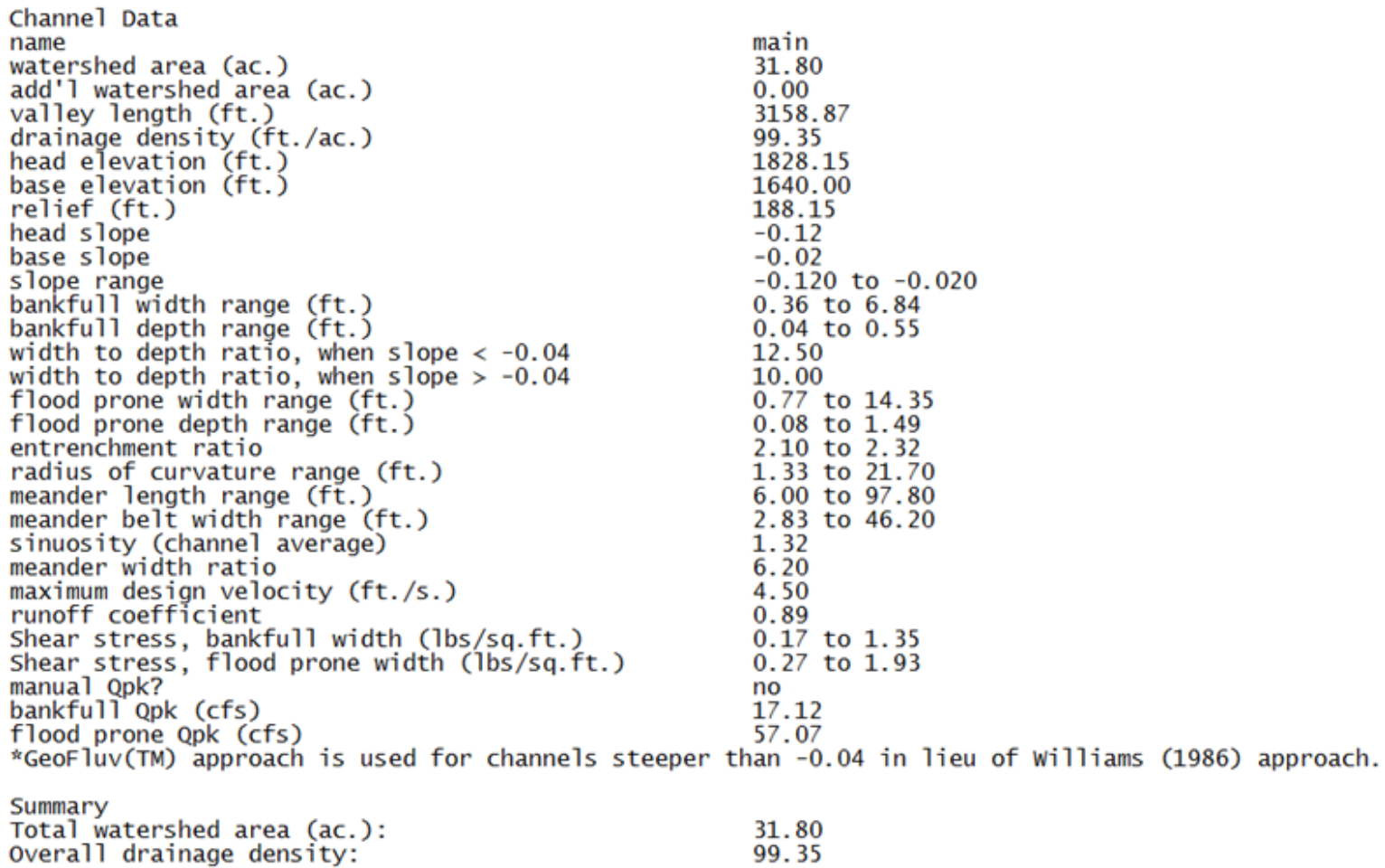

Subwatershed 3, highlighted in purple, as shown below in Figure 4.2.10, was analyzed third because it was located adjacent to Subwatershed land 2 valley-fills that were previously created. Subwatershed 3 analysis used the original topography as well as the created Subwatershed 1 and 2 topography so that the created landforms would merge smoothly. Subwatershed covered approximately 36 ac and varied in elevation from $1650 \mathrm{ft}$ to $1995 \mathrm{ft}$. It also contained no original stream length. The valley fill created using Natural Regrade ${ }^{\circledR}$ had a greater amount of stream length within the same area compared to the original stream length in order for the target drainage density to be achieved (Table 6.0.1). The original topography of Subwatershed 3 showed a ridge running along the northern and western sides of this property and sloped down toward the southern side. This watershed connected to the previously created Subwatersheds 1 and 2 along the northern and eastern sides and bordered one other subwatershed 
located along the western side of the property. This subwatershed was analyzed later in this section.

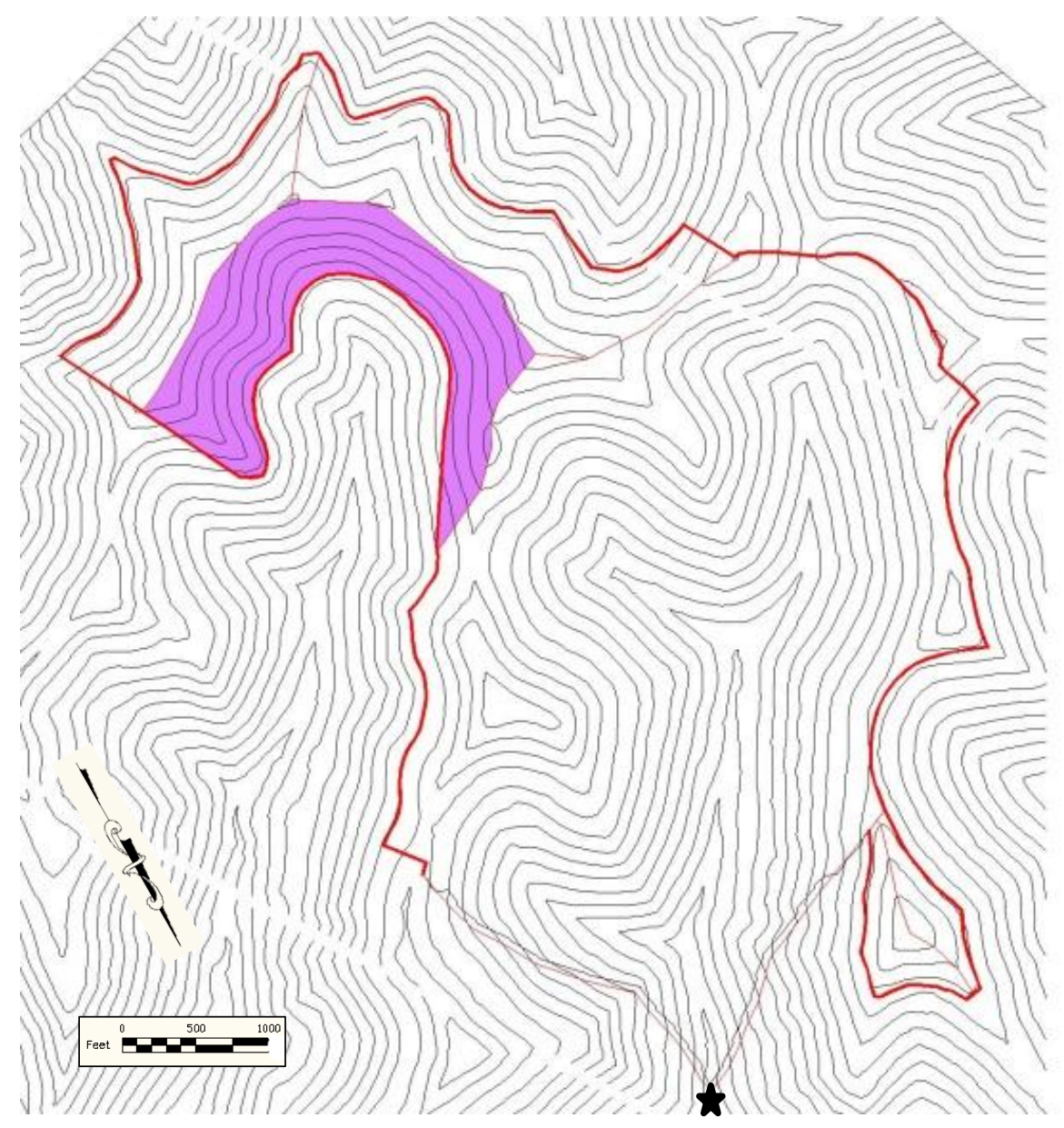

Figure 4.2.10: Third Subwatershed Analyzed: "Subwatershed 3"

The stream channel created for the geomorphic design in the area associated with Subwatershed 3 is shown in Figure 4.2.11. The design was characterized by a single main channel that flowed through the property. 


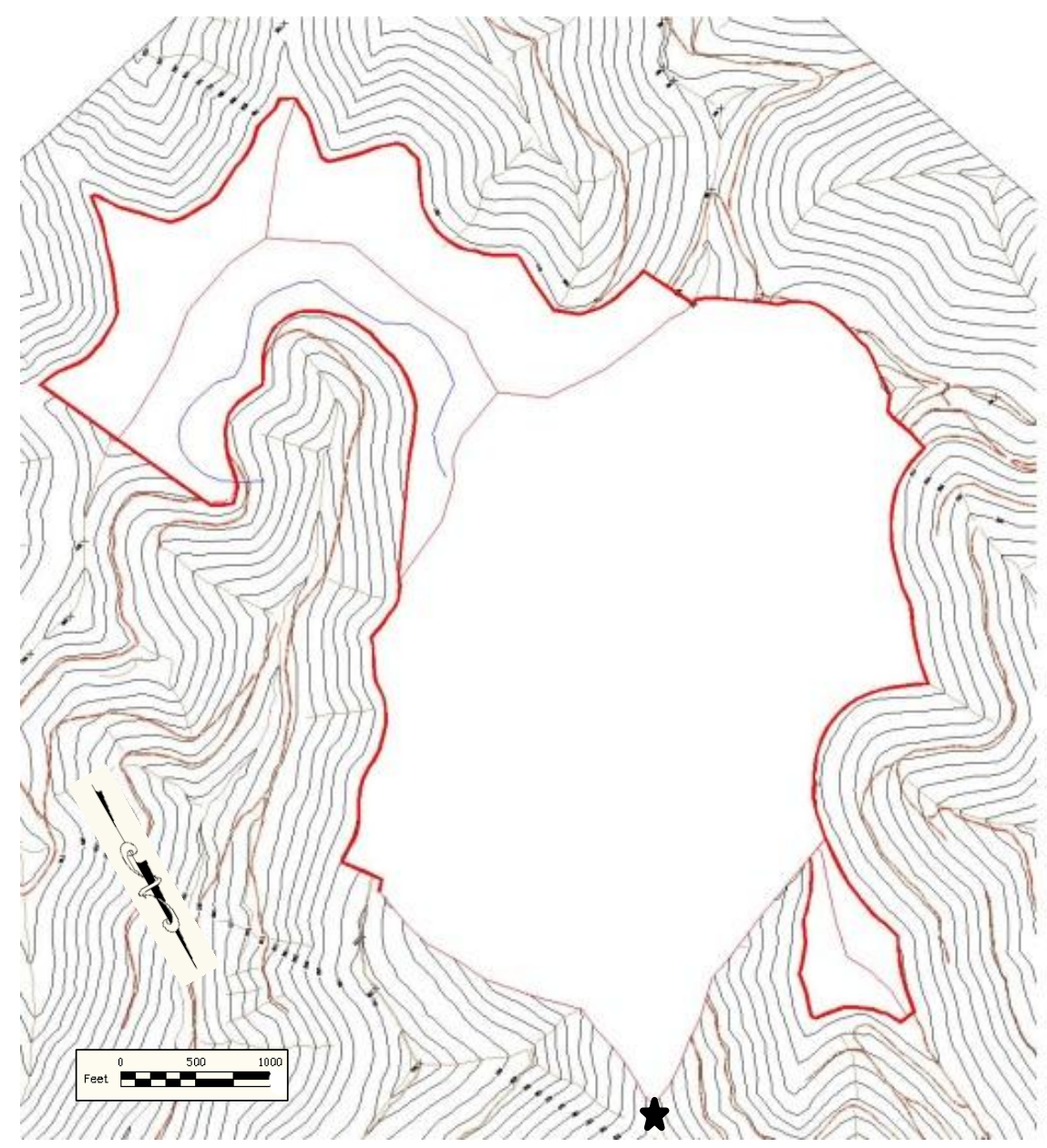

Figure 4.2.11: Streams Created in Subwatershed 3

A close-up view of the created drainage channel within the third subwatershed is shown in Figure 4.2.12. The main channel was labeled and was approximately $3700 \mathrm{ft}$ long. 


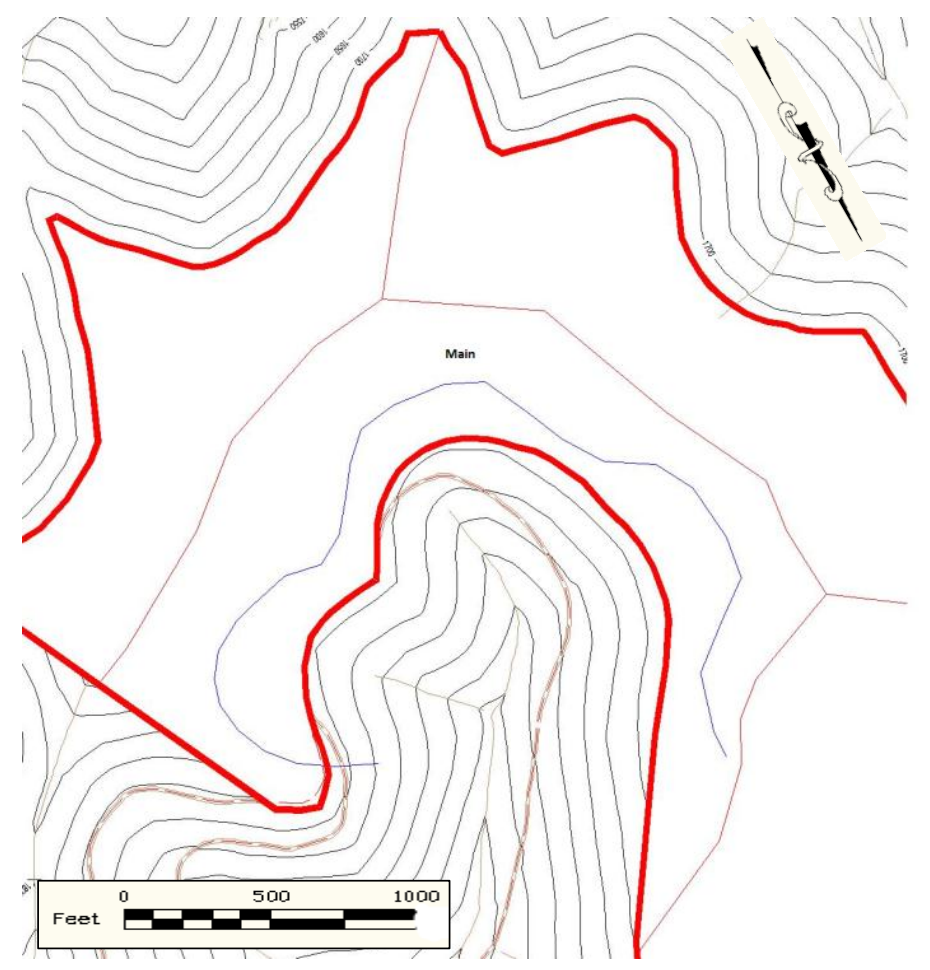

Figure 4.2.12: Subwatershed 3 with Labeled Created Stream

The geomorphic landform valley-fill design created using the previously mentioned methodologies and principles is shown in the three-dimensional Figure 4.2.13. 


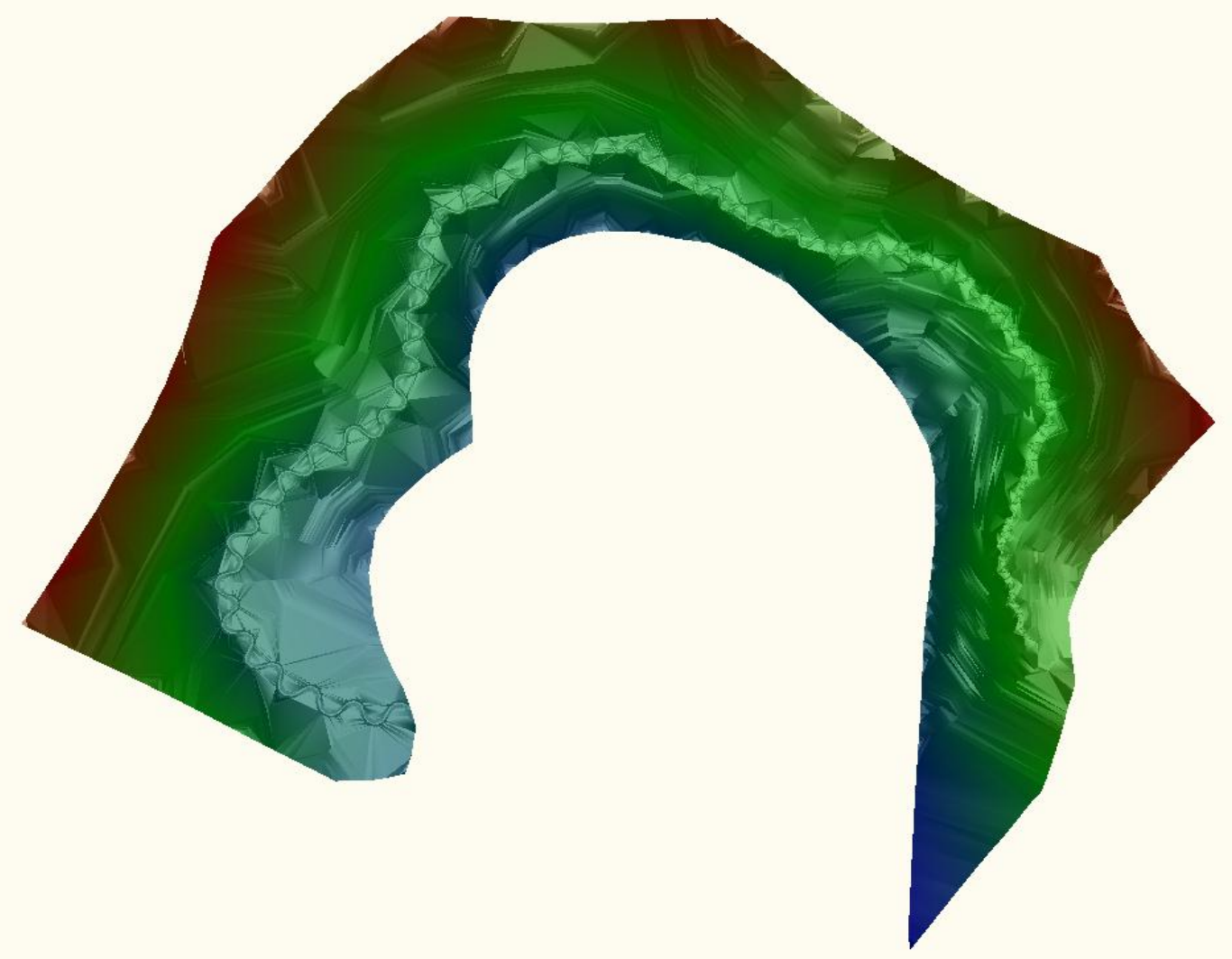

Figure 4.2.13: Completed Subwatershed 3 Geomorphic Valley-fill Design

The wide range of information obtained from the created valley-fill design is shown in Table 4.2.6. The watershed area that supplied the stream channel was 35.95 ac for Subwatershed 3. The overall resulting drainage density for the subwatershed was $98.76 \mathrm{ft} / \mathrm{ac}$ (Table 4.2.6). The design added a total of 3700 feet of channel length (Table 6.0.1), including type A and type C channels. 


\section{Table 4.2.6: Channel Data for Subwatershed 3 Channel Main and Total Summary Data}

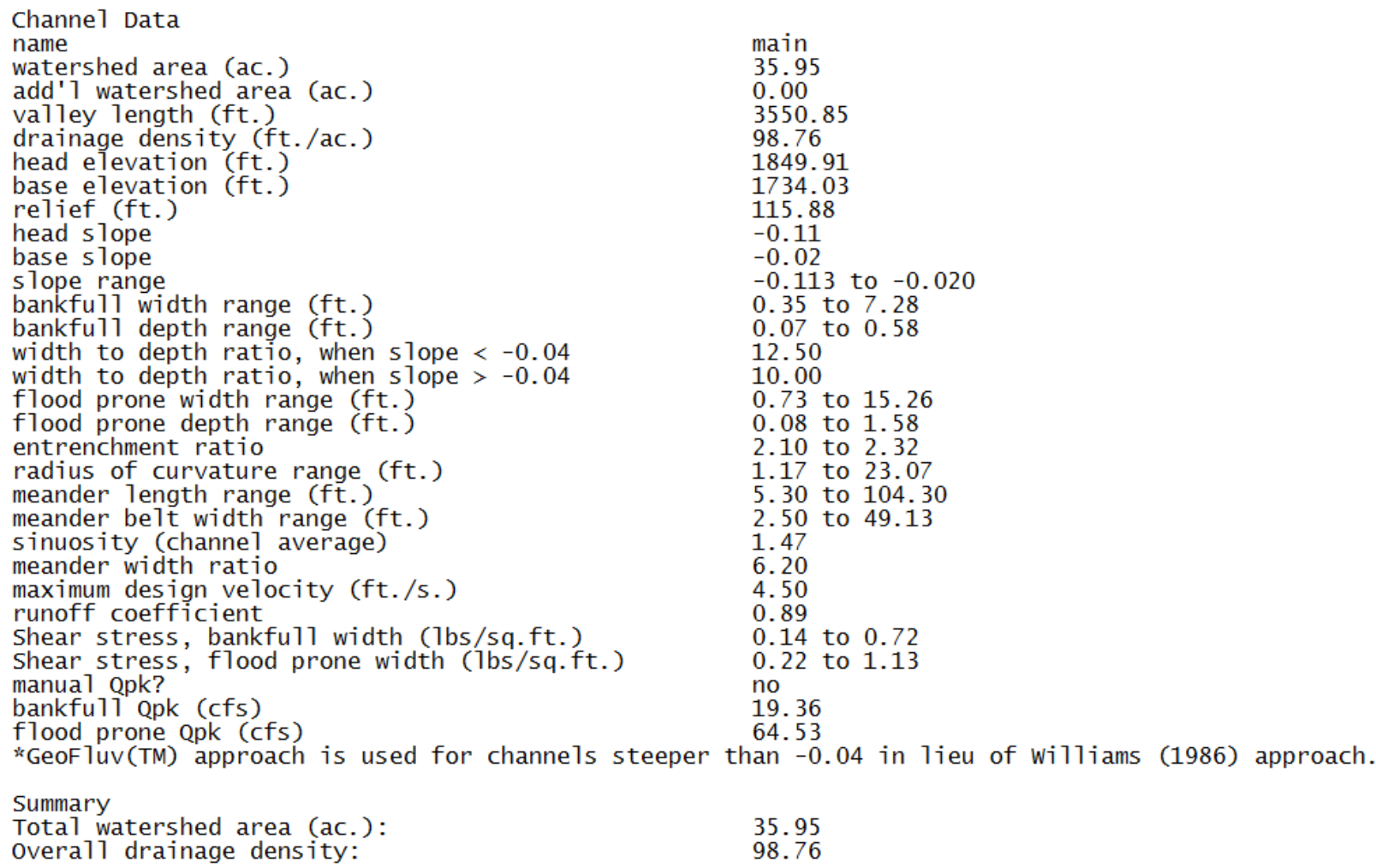

Subwatershed 4, highlighted in pink in Figure 4.2.14, was analyzed fourth because it was located adjacent to the valley fills of Subwatersheds 2 and 3 that were previously created.

Subwatershed 4 analysis used the original topography as well as the created 1, 2, and 3 subwatershed topography so that the created landforms would merge smoothly. Subwatershed 4 covered approximately $21 \mathrm{ac}$ and varied in elevation from $1720 \mathrm{ft}$ to $1993 \mathrm{ft}$. It also contained over $460 \mathrm{ft}$ of original stream length. The original topography of the fourth subwatershed showed a ridge running along the south eastern side of this property and sloped down toward the north western side. It connected to the previously created Subwatersheds 2 and 3 along the eastern side of the property. 


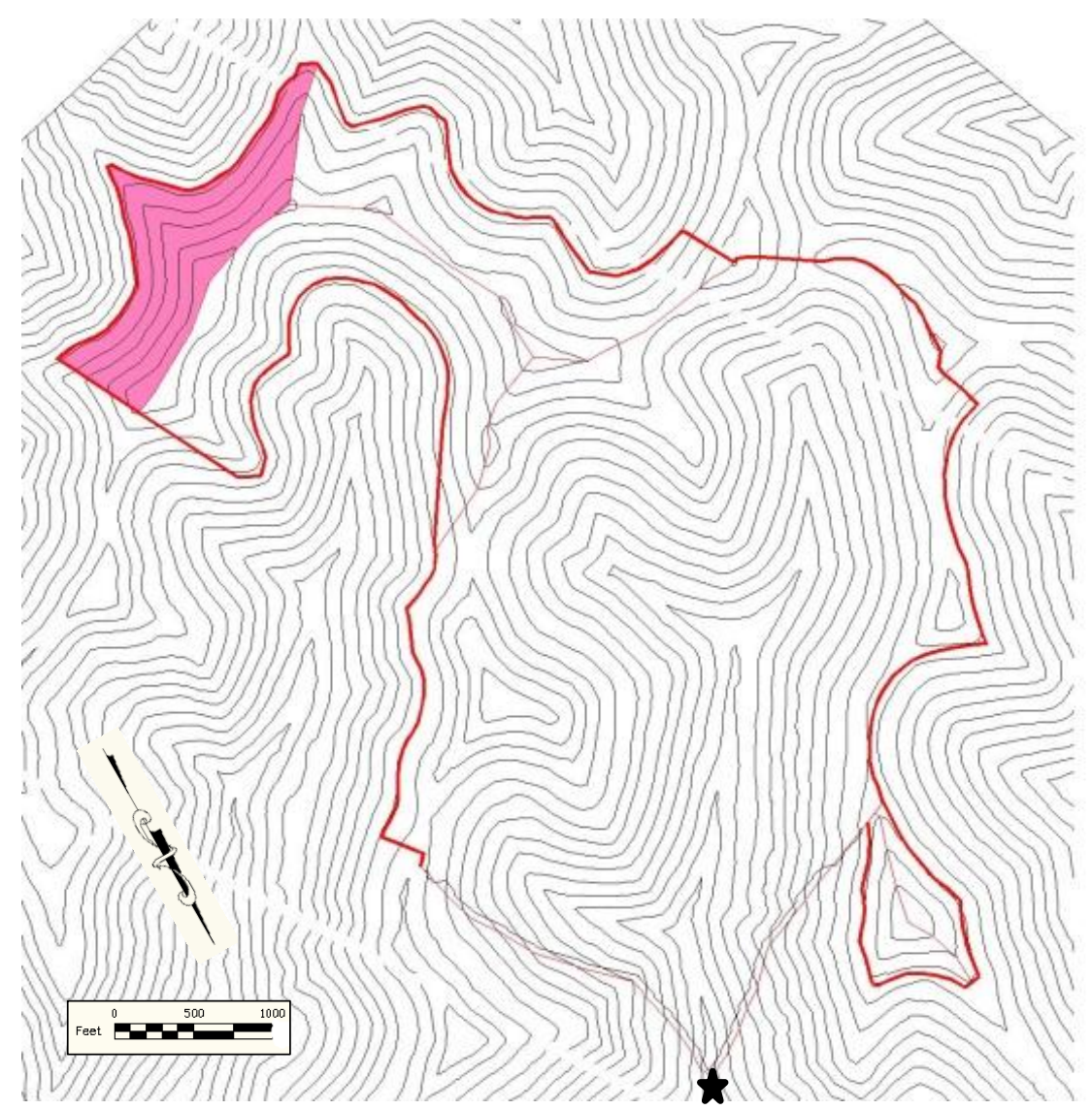

Figure 4.2.14: Fourth Subwatershed Analyzed: "Subwatershed 4”

The stream channels created for the geomorphic design in the area associated with Subwatershed 4 are shown in Figure 4.2.15. The design was characterized by a single main channel and one tributary channel that flowed through the property. 


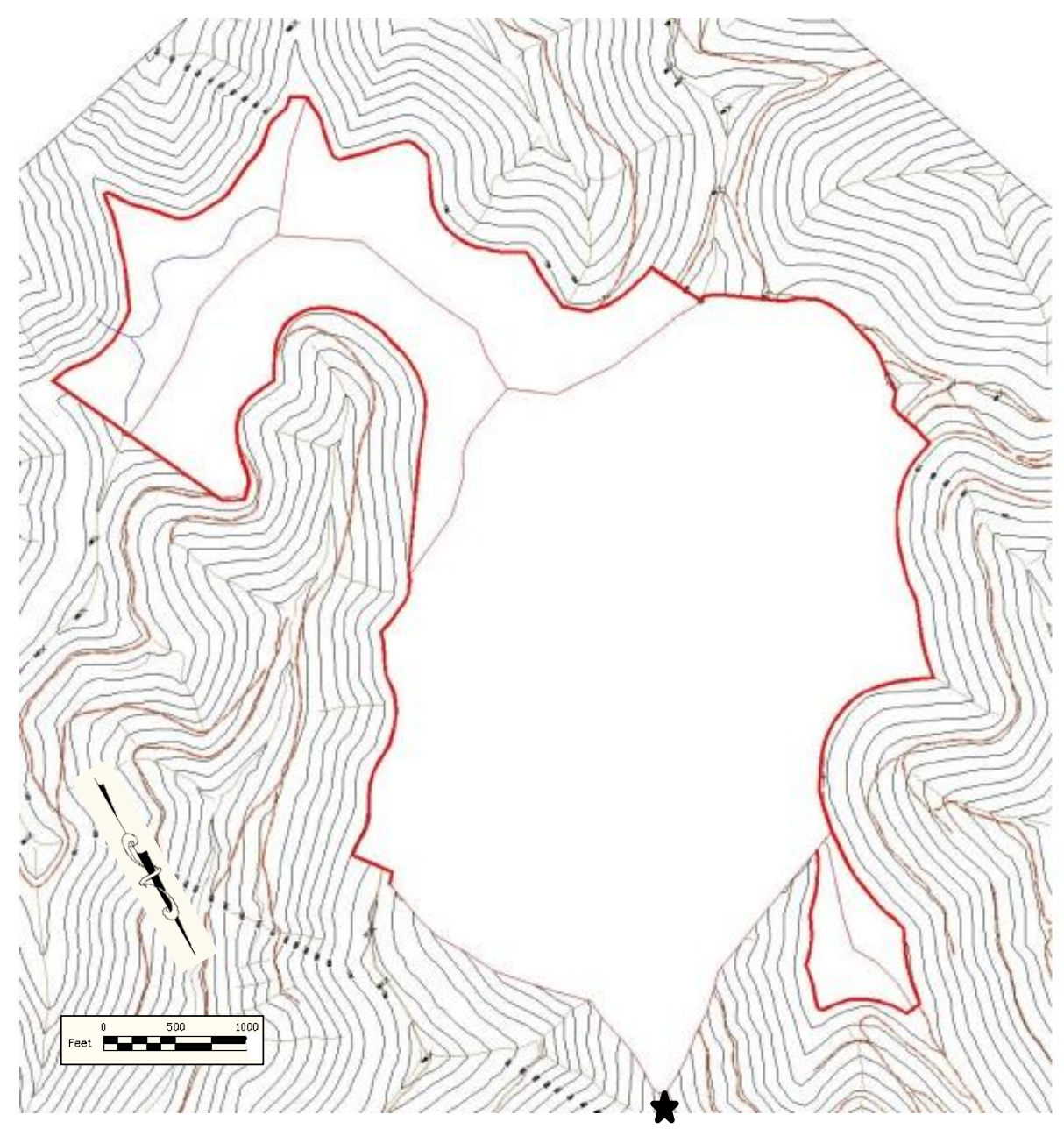

Figure 4.2.15: Subwatershed 4 and Streams Created in that Watershed

A close-up view of the created drainage channel within the fourth subwatershed is shown in Figure 4.2.16. The main and tributary channels were labeled "Main" and "L1" according to their position with respect to the main channel. The channels ranged in length from almost 580 $\mathrm{ft}$ to $1664 \mathrm{ft}$. 


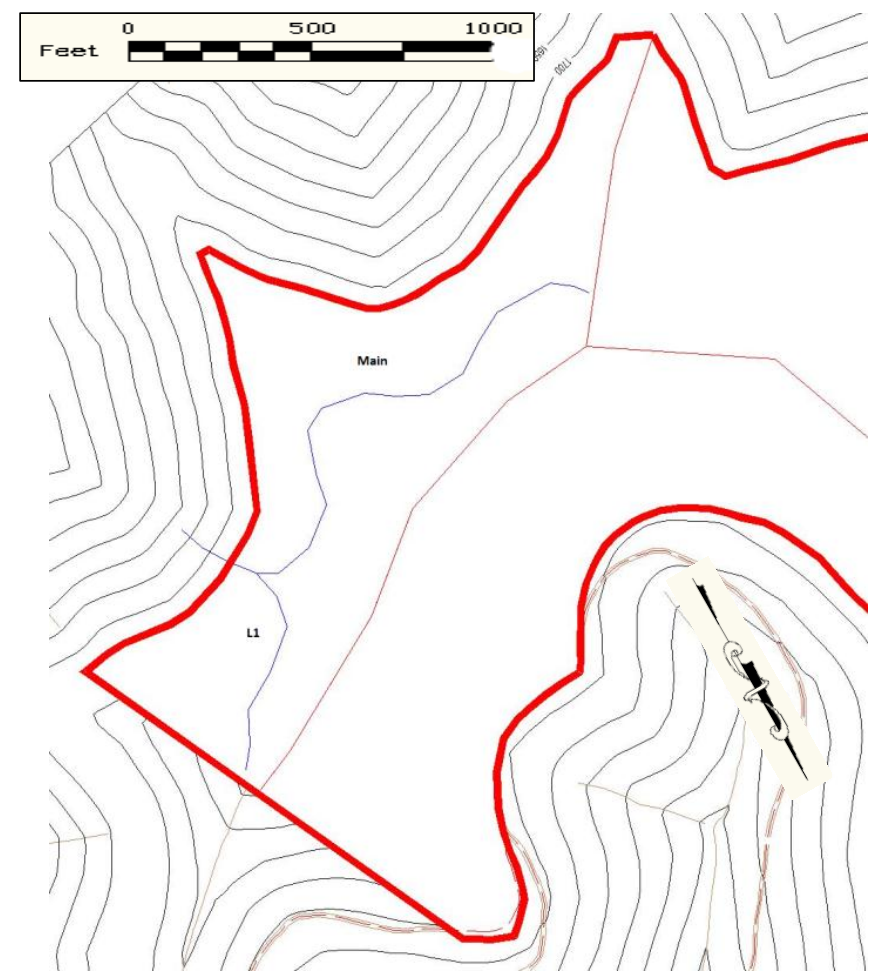

Figure 4.2.16: Subwatershed 4 with Labeled Created Streams

The geomorphic landform design principles and methods were applied to Subwatershed 4 after the channels were created and the drainage density of each channel was verified to be within the targeted area. The three-dimensional Figure 4.2.17 shows the completed valley-fill design of Subwatershed 4. 


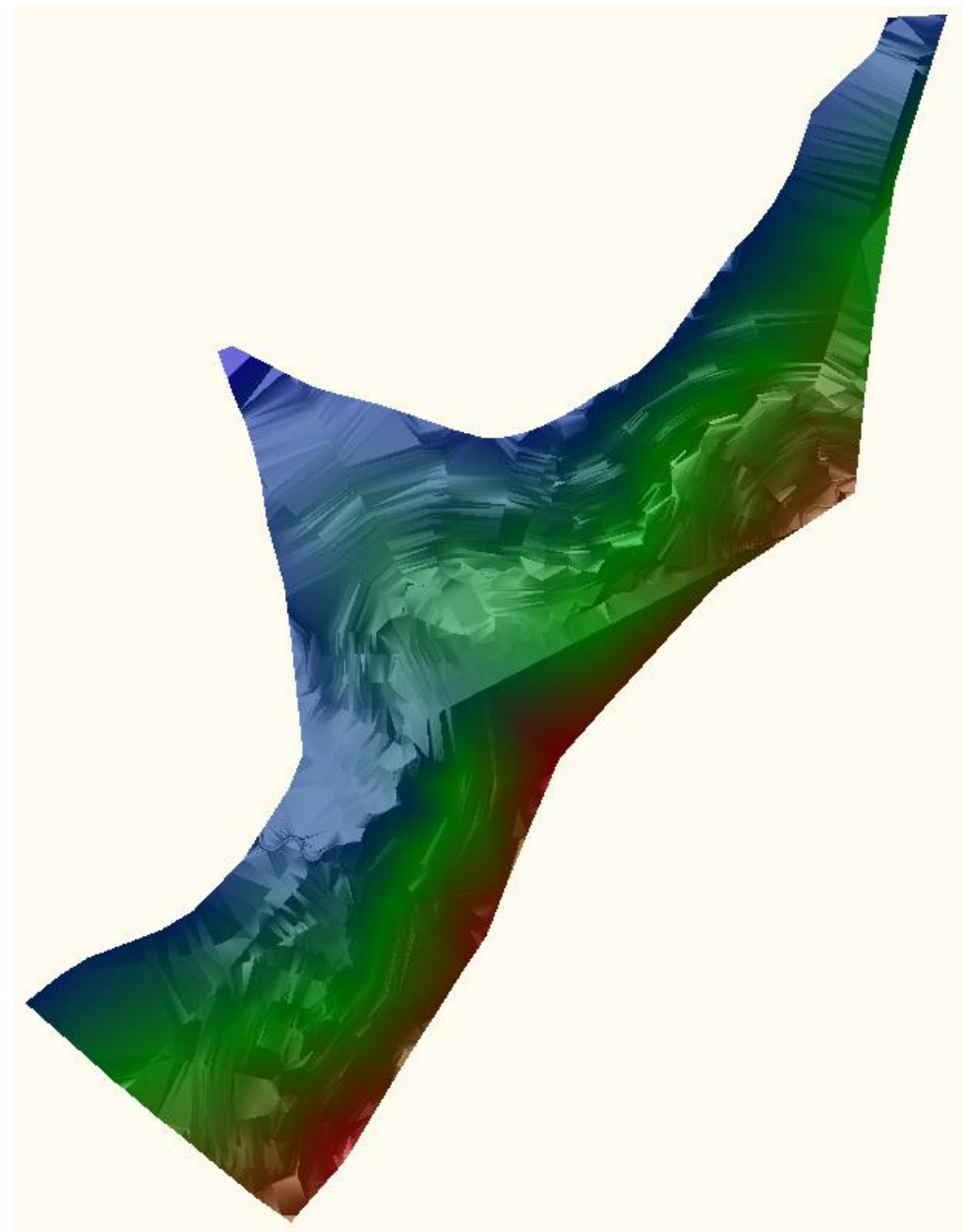

Figure 4.2.17: Completed Subwatershed 4 Geomorphic Valley-fill Design

Table 4.2.7 contains a large amount of data from the created geomorphic landform reclamation design. The watershed area that supplied the stream channel was 21.19 ac for Subwatershed 4. The overall resulting drainage density for the subwatershed was $98.42 \mathrm{ft} / \mathrm{ac}$ (Table 4.2.7). The design added a total of $2244 \mathrm{ft}$ of channel length (Table 6.0.1), including type A and type $\mathrm{C}$ channels. 


\section{Table 4.2.7: Channel Data for Subwatershed 4 Channels Main, L1,}

and Total Summary Data

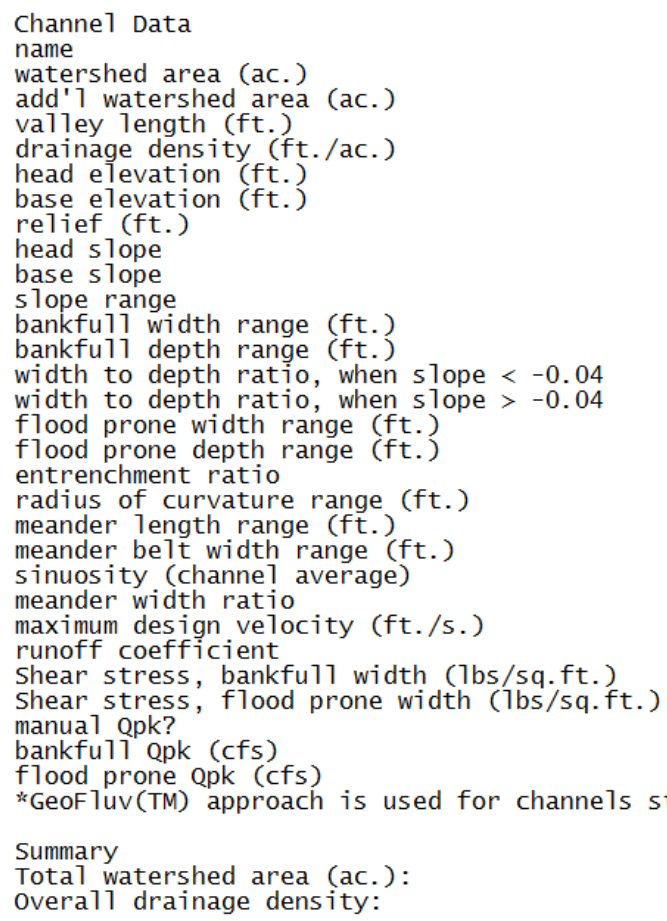

main
21.19
0.00
1505.55
98.42
1903.10
1740.54
162.55
-0.12
-0.02
-0.120 to -0.020
0.41 to 5.57
0.04 to 0.45
12.50
10.00
0.85 to 11.68
0.09 to 1.21
2.10 to 2.32
1.19 to 18.32
5.36 to 80.19
2.54 to 39.01
1.17
6.25
4.50
0.89
0.19 to 2.46
0.30 to 3.53
no
11.41
38.03
1901

L1
4.99
0.00
580.10
116.33
1954.91
1743.18
211.73
-0.33
-0.16
-0.331 to -0.161
0.35 to 2.68
0.04 to 0.21
12.50
10.00
0.73 to 5.66
0.08 to 0.65
2.10 to 2.32
1.13 to 8.71
5.04 to 38.90
2.40 to 18.54
1.14
6.31
4.50
0.89
0.46 to 5.03
0.73 to 7.21
no
2.69
8.95

$38.03 \quad 8.95$

$\begin{array}{ll}\text { Total watershed area (ac.): } & 21.19 \\ \text { overal1 drainage density: } & 98.42\end{array}$

Subwatershed 5, highlighted in yellow, as shown below in Figure 4.2.18, was analyzed fifth because it was the smallest subwatershed and was located adjacent to Subwatershed 1 valley fill that was previously created. This subwatershed was located in the south eastern corner of the boundary and bordered Subwatershed 1 by only $1730 \mathrm{ft}$. Subwatershed 5 analysis used the original topography as well as the created topography of Subwatersheds $1,2,3$, and 4 so that the created landforms would merge smoothly. The subwatershed covered approximately 4 ac and varied in elevation from $1780 \mathrm{ft}$ to $1897 \mathrm{ft}$. It also contained no original stream length. The valley fill created using Natural Regrade ${ }^{\circledR}$ had a greater amount of stream length within the same area compared to the original stream length (Table 6.0.1). The original topography of Subwatershed 5 showed a ridge running along the eastern side of this property and sloped down 
toward the northern, southern, and western sides. It connected to the previously created Subwatershed 1 along the northern side of the property.

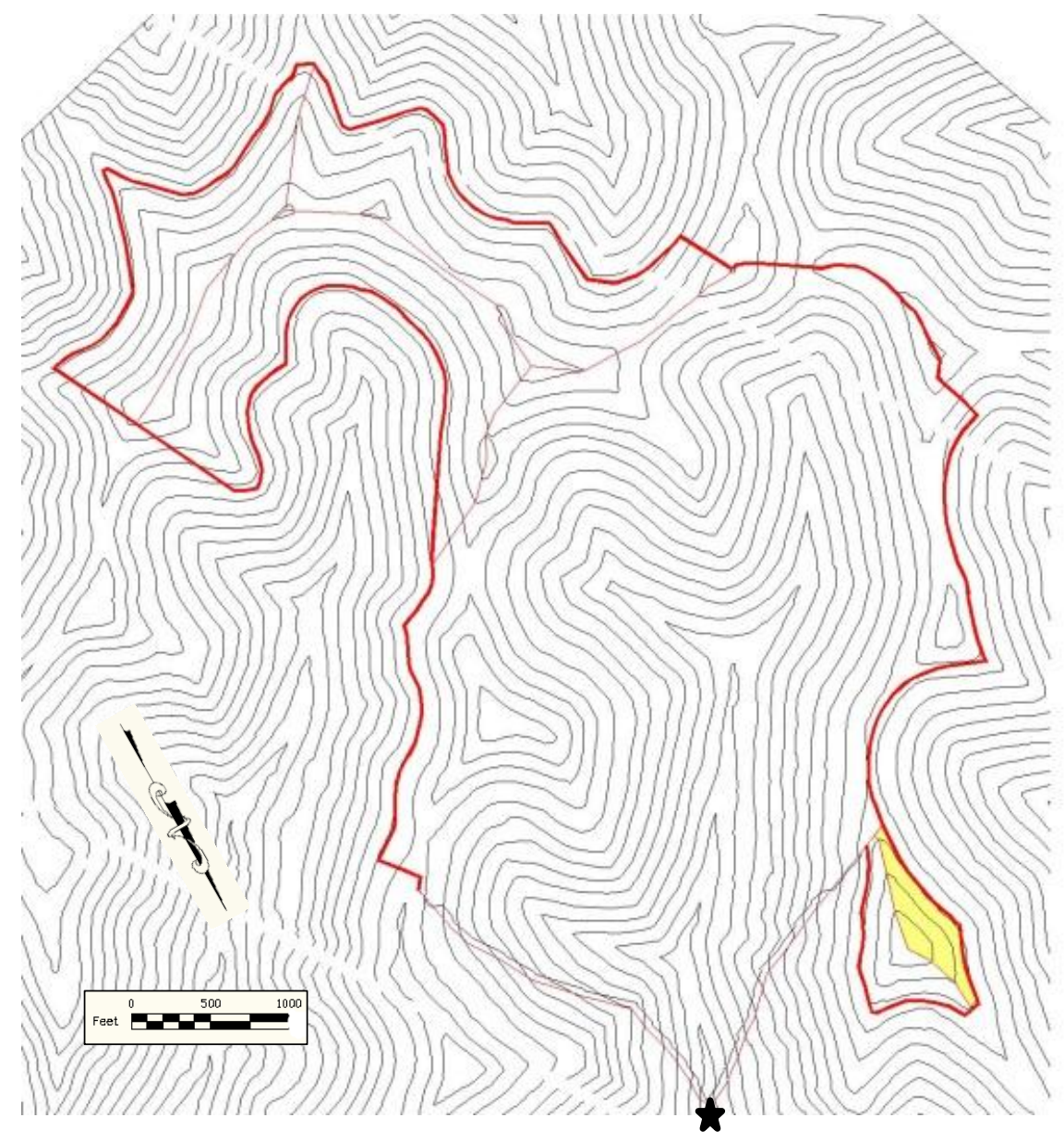

Figure 4.2.18: Fifth Subwatershed Analyzed: "Subwatershed 5"

Figure 4.2.19 shows the stream channel created within Subwatershed 5. The design was characterized by a single main channel that flowed through the property. 


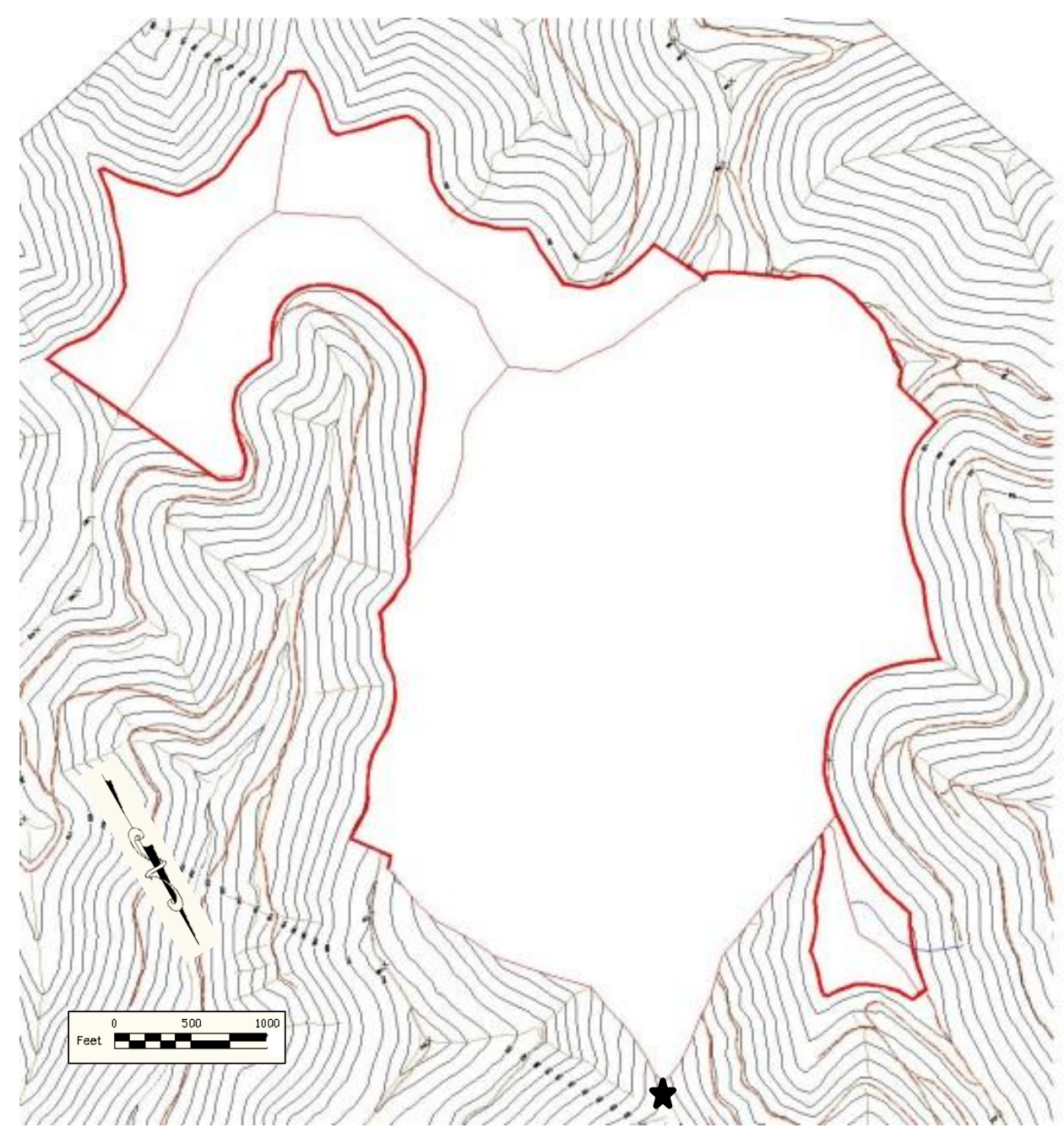

Figure 4.2.19: Subwatershed 5 and Stream Created in that Watershed

A close-up view of the created drainage channel within the fifth subwatershed is shown in Figure 4.2.20. The main channel was labeled and had a length of $789 \mathrm{ft}$. 


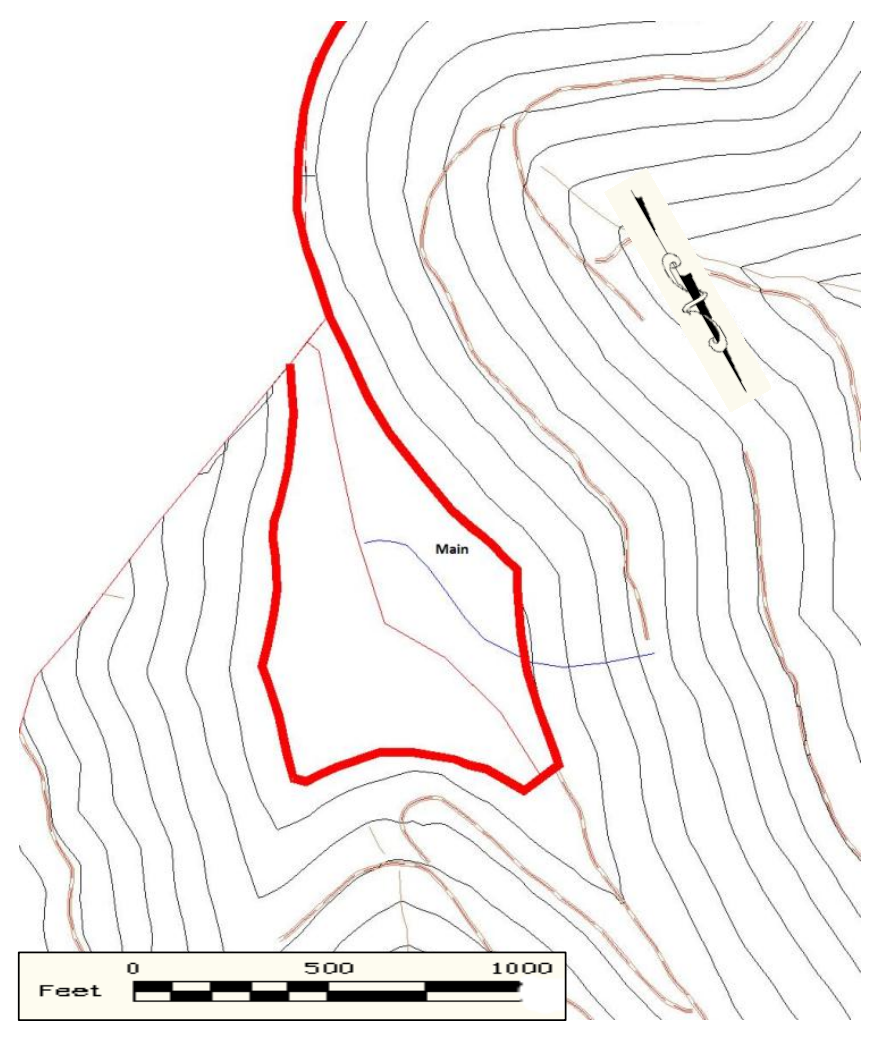

Figure 4.2.20: Subwatershed 5 with Labeled Created Stream

The geomorphic landform valley-fill design created using the previously mentioned methodologies and principles is shown in the three-dimensional Figure 4.2.21. 


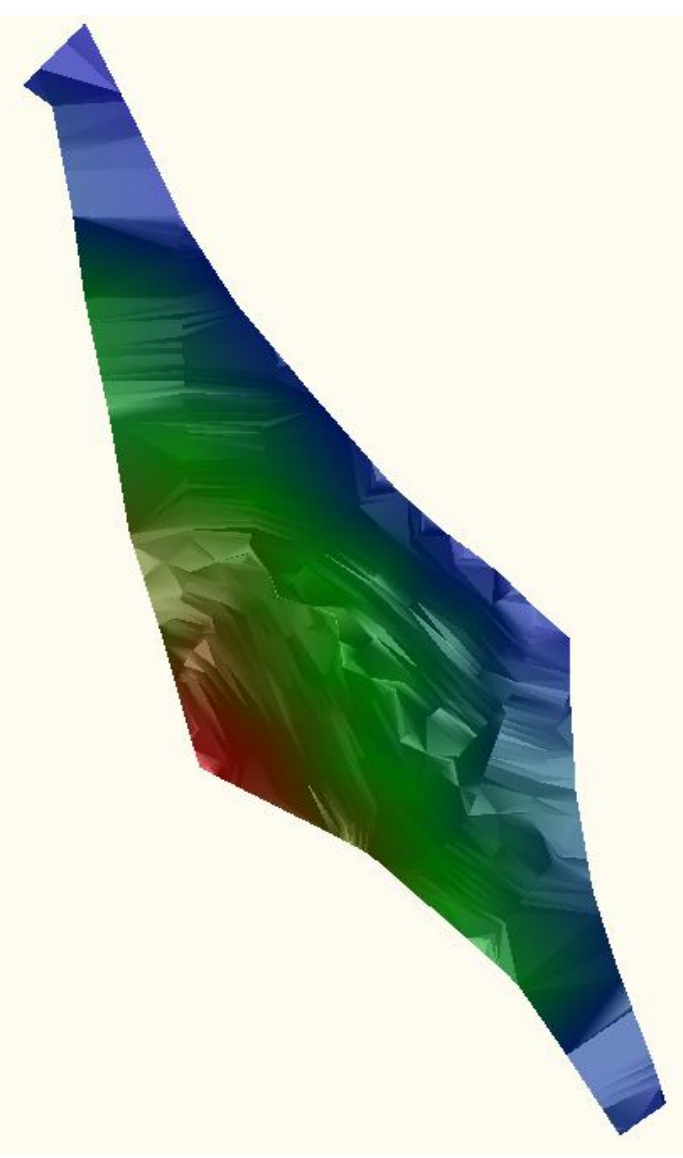

Figure 4.2.21: Completed Subwatershed 5 Geomorphic Valley-fill Design

The large amount of information obtained from the valley-fill design is shown below in Table 4.2.8. The watershed area that supplied the stream channel was 4.18 ac for Subwatershed

5. The overall resulting drainage density for the subwatershed was $116.78 \mathrm{ft} / \mathrm{ac}$ (Table 4.2.8). The design added a total of $789 \mathrm{ft}$ of channel length (Table 6.0.1), including type A and type C channels. 


\section{Table 4.2.8: Channel Data for Subwatershed 5 Channel Main and Total Summary Data}

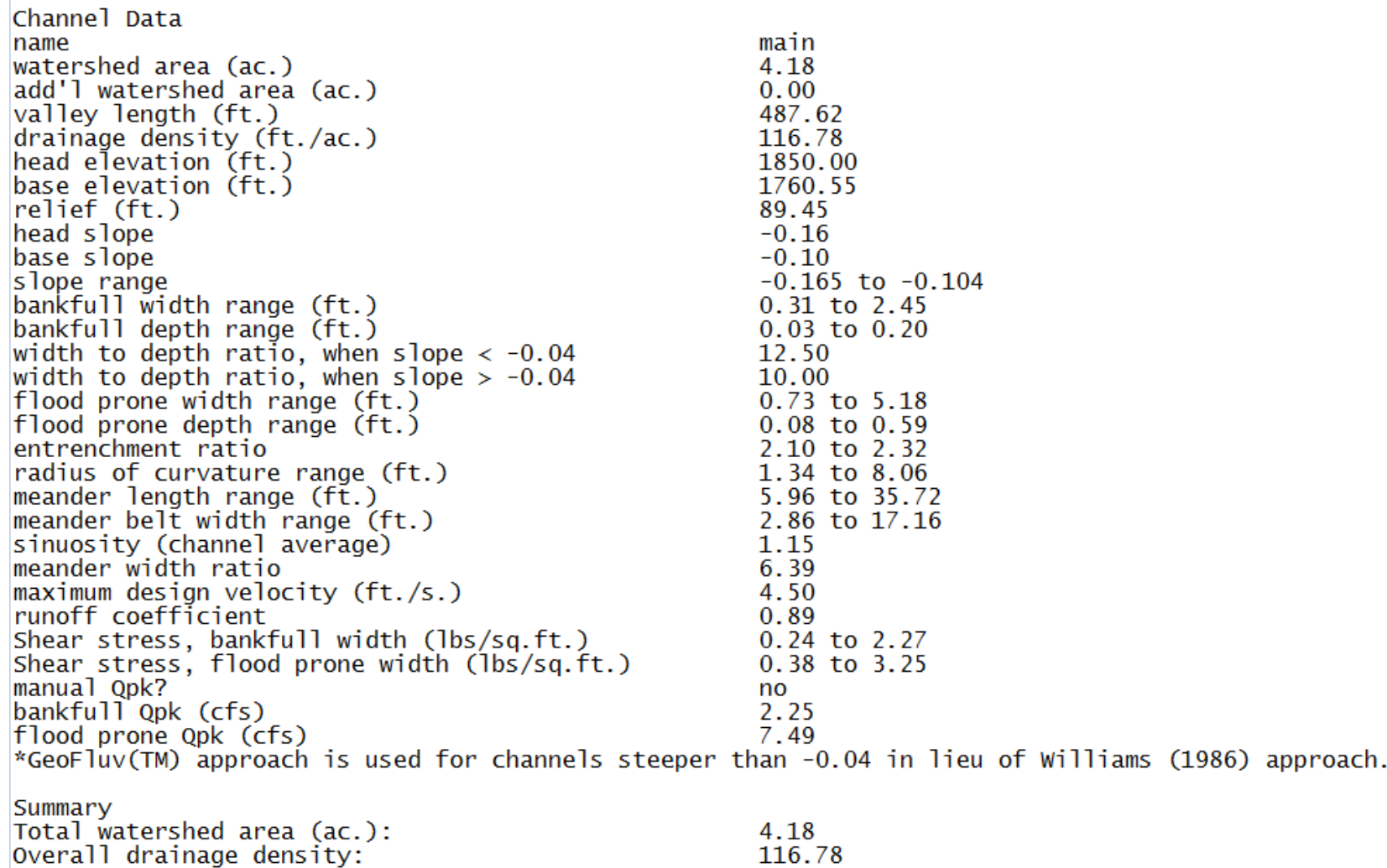

Subwatershed 6, highlighted in orange, as shown in Figure 4.2.22, was analyzed last because it was the second smallest subwatershed and was located adjacent to Subwatershed 1 and 5 valley fills that were previously created. This subwatershed was located in the south eastern corner of the boundary and bordered Subwatershed 1 by only $1720 \mathrm{ft}$. The subwatershed 6 analysis used the original topography as well as the created topography of Subwatershed 1, 2, 3,4 , and 5 so that the created landforms would merge smoothly. The subwatershed covered almost six acres and varied in elevation from $1720 \mathrm{ft}$ to $1900 \mathrm{ft}$. It also contained no original stream length. The valley fill created using Natural Regrade ${ }^{\circledR}$ had a greater amount of stream length within the same area compared to the original stream length (Table 6.0.1). The original topography of Subwatershed 6 showed a ridge running along the western side of this property and sloped down toward the northern, southern, and eastern sides. It connected to the previously 
created Subwatershed 1 along the northern side of the property and the Subwatershed 5 along the eastern side.

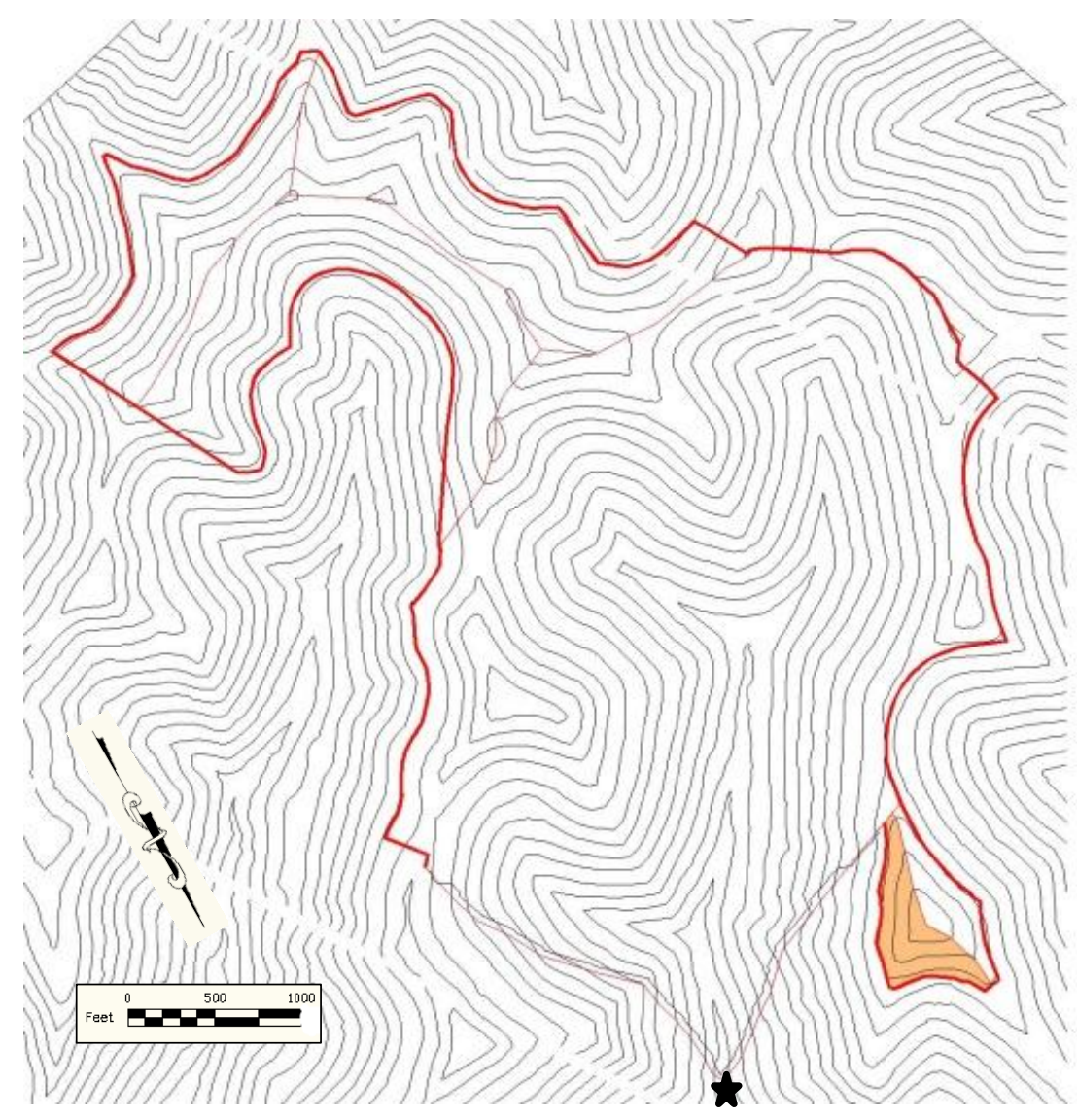

Figure 4.2.22: Last Subwatershed Analyzed: "Subwatershed 6"

The stream channel created for the geomorphic design in the area associated with the sixth subwatershed is shown in Figure 4.2.23. The design was characterized by a single main channel that flowed through the property. 


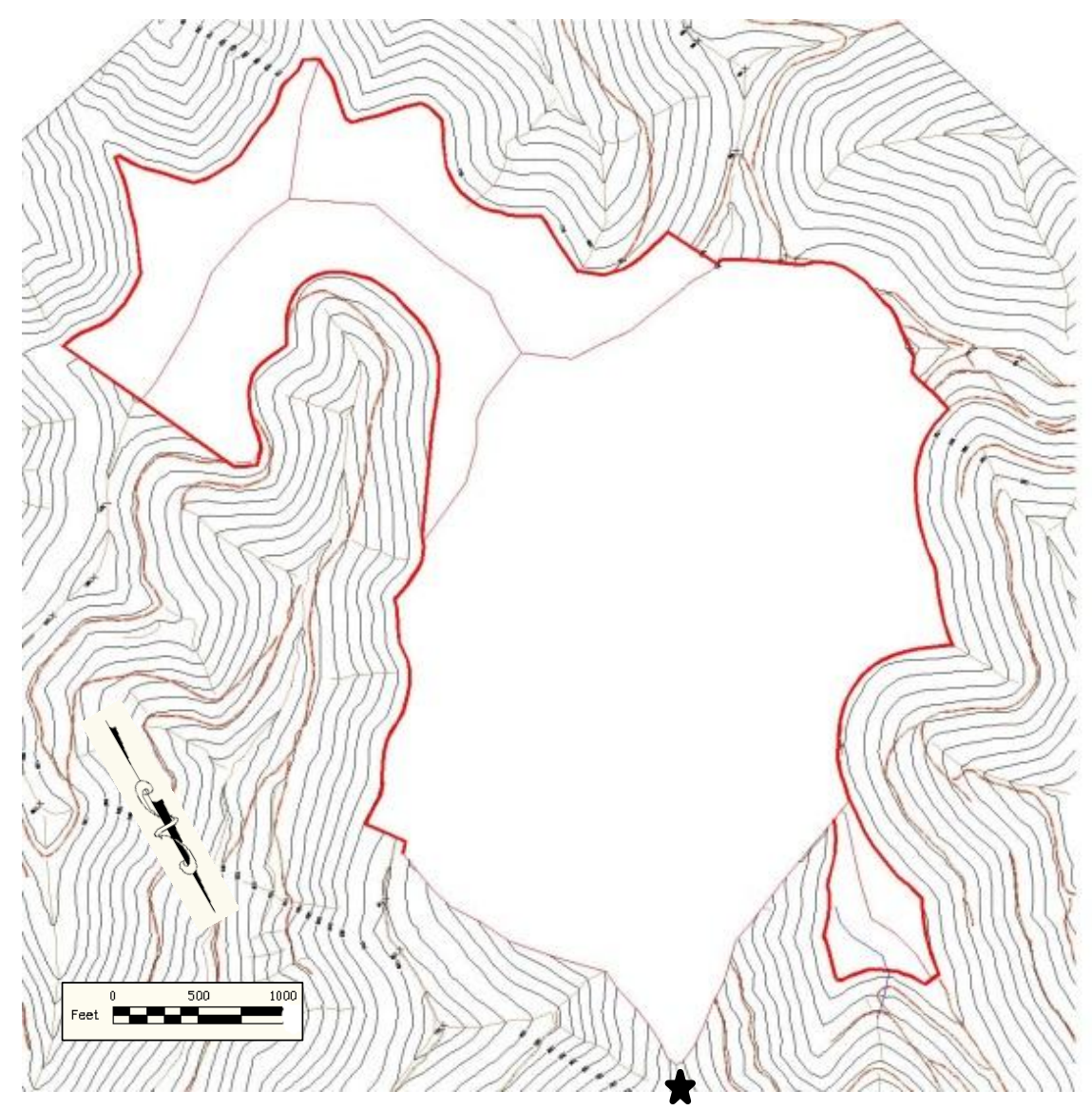

Figure 4.2.23: Subwatershed 6 and Stream Created in that Watershed

Figure 4.2.24 shows a closer view of the created stream channel within the orange subwatershed. The main channel was labeled and had a length of $809 \mathrm{ft}$. 


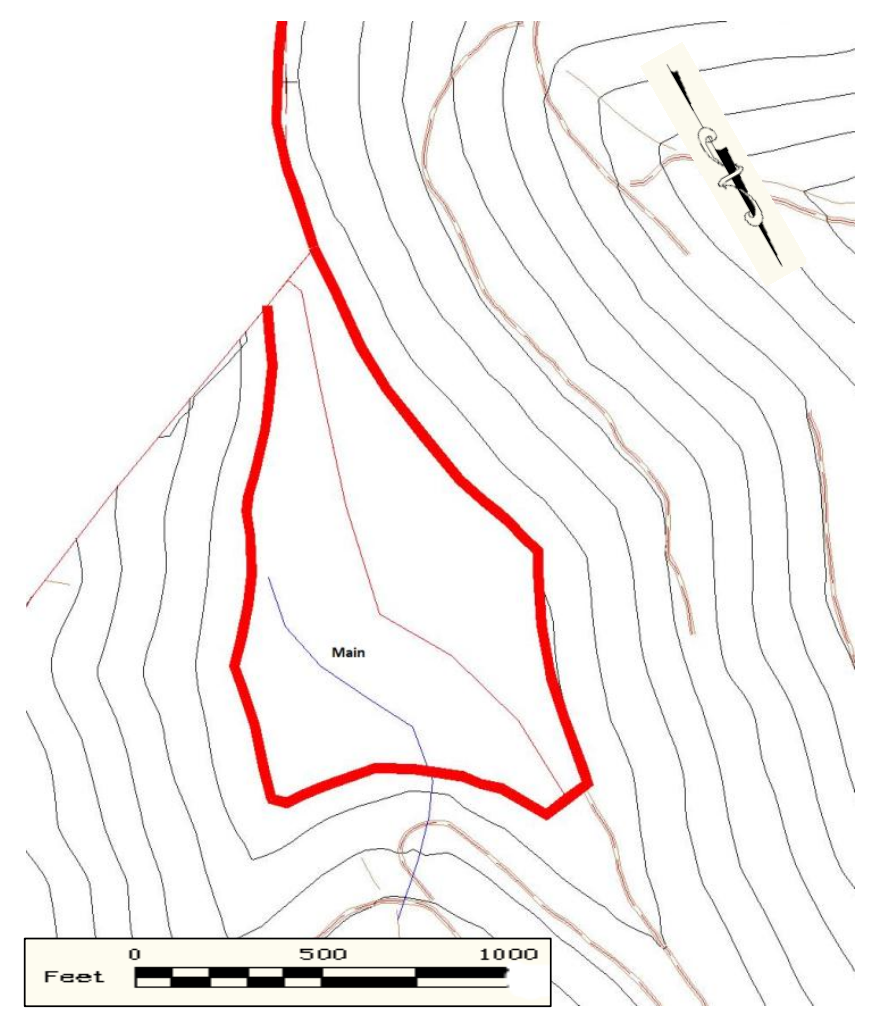

Figure 4.2.24: Subwatershed 6 with Labeled Created Stream

The valley fill that was created using Natural Regrade ${ }^{\circledR}$ with GeoFluv ${ }^{\mathrm{TM}}$ is shown in the three-dimensional Figure 4.2.25. 


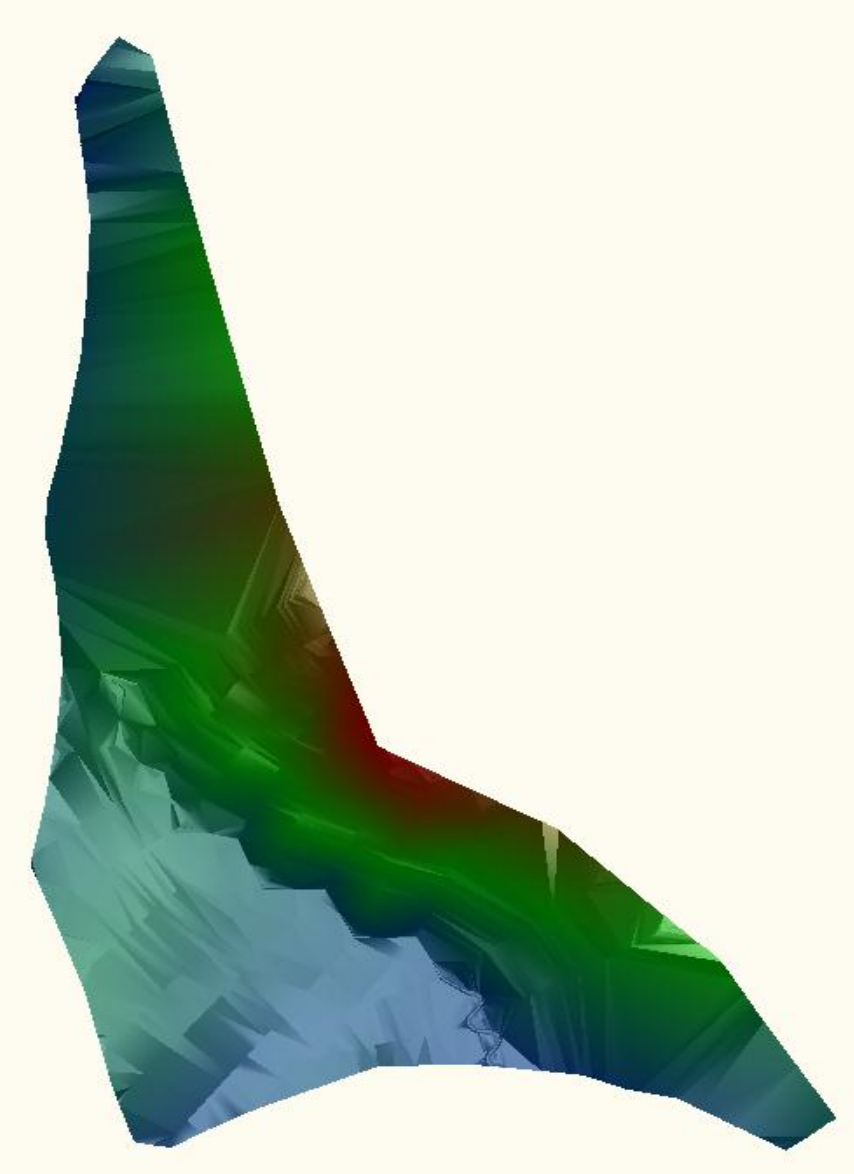

Figure 4.2.25: Completed Subwatershed 6 Geomorphic Valley-fill Design

The information obtained from the created geomorphic landform reclamation design of Subwatershed 6 is shown in Table 4.2.9. The watershed area that supplies the stream channel was 5.67 ac for Subwatershed 6. The overall resulting drainage density for the subwatershed was $90.09 \mathrm{ft} / \mathrm{ac}$ (Table 4.2.9). The design added a total of $809 \mathrm{ft}$ of channel length (Table 6.0.1), including type $\mathrm{A}$ and type $\mathrm{C}$ channels. 


\section{Table 4.2.9: Channel Data for Subwatershed 6 Channel Main and Total Summary Data}

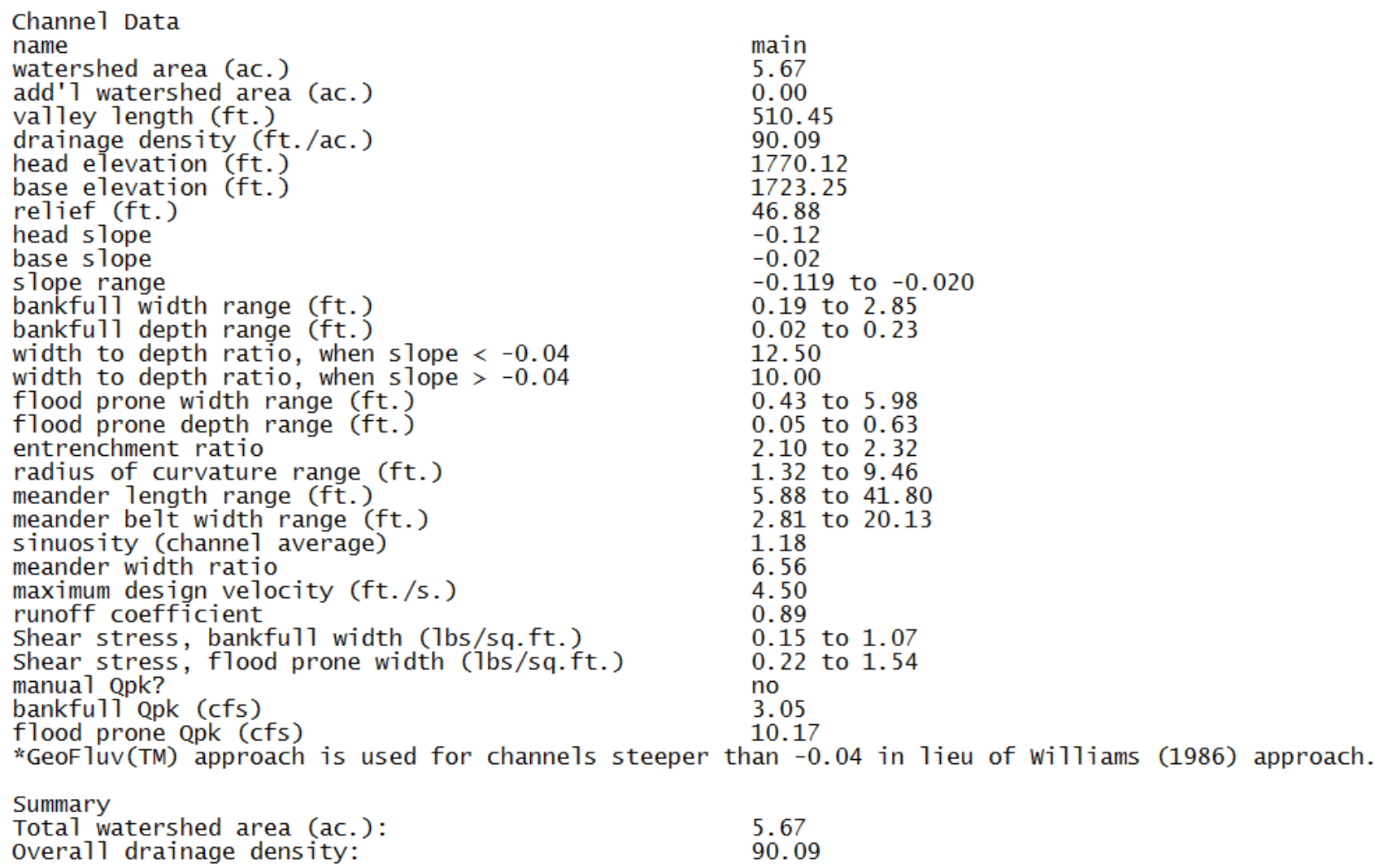

Once all of the subwatershed designs were created using Natural Regrade ${ }^{\circledR}$ with GeoFluv $^{\mathrm{TM}}$, they were combined so that the valley-fill design was complete. All of the data for each analyzed subwatershed was compiled so that a proper analysis of the total design was completed.

The overall geomorphic reclamation design of the sample site saved a total of $1200 \mathrm{ft}$ of original stream length at the toe of the valley fill (Table 6.0.1). Using Natural Regrade ${ }^{\circledR}$ principles, almost 33,000 ft or six and a quarter miles of stream length (type A and type C channels as defined by Rosgen) was created on the property (Table 6.0.1). Figure 4.2.26 shows the location of all the created stream channels. 


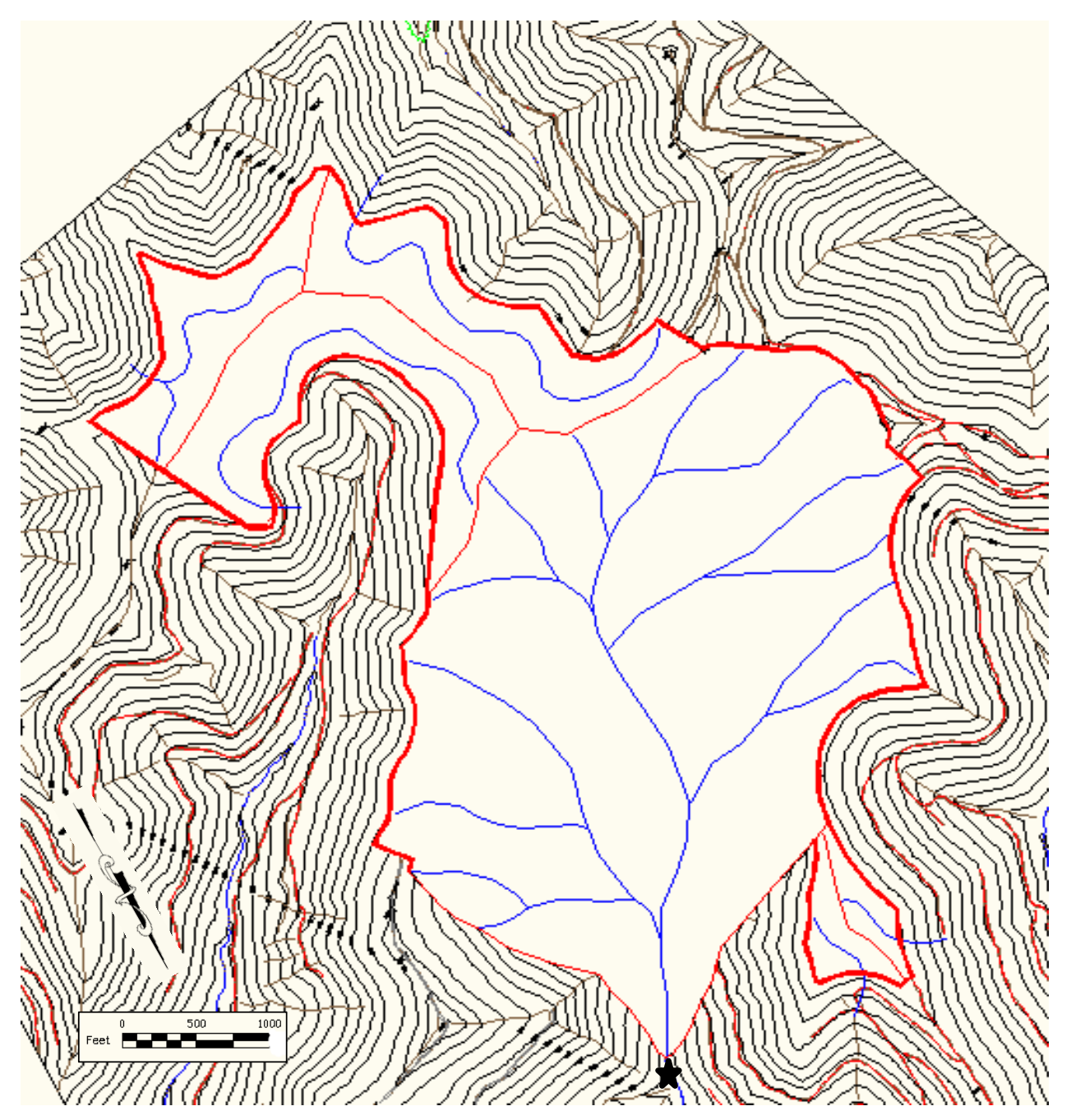

Figure 4.2.26: Stream Channels Created Using Fluvial Geomorphic Principles

\subsection{Fill Balance}

Since each subwatershed design included the created topographic contours of the previous subwatersheds, once the sixth subwatershed design was completed, all of the contours had been created. The amount of fill was then analyzed and compared to the amount of fill in the traditional valley-fill design of the sample site. The traditional design contained approximately 90 million cubic yards of fill material whereas the geomorphic landform design contained only 60 million cubic yards of fill material. Therefore, the ridges were manually increased using the "Edit Longitudinal Profile" that was located in the "Edit design surface in drawing" tab in order 
to increase the fill capacity of the design. Once all of the edits were completed, the valley fill was increased to 75 million cubic yards. Even though this was still less than the amount of fill in the traditional valley fill, the cut and fill amounts were balanced in the design, so it was considered to be a comprehensive design. The ridges could not be increased any more, to be closer to the 90 million cubic yards, because the topography would become too steep and unstable. Therefore, creating a stable, balanced design took priority over matching the amount of fill material in the traditional valley-fill design. The topographic contours were then recalculated to match the edited ridgelines. These edited contours are shown below in Figures 4.3.1 and 4.3.2. 


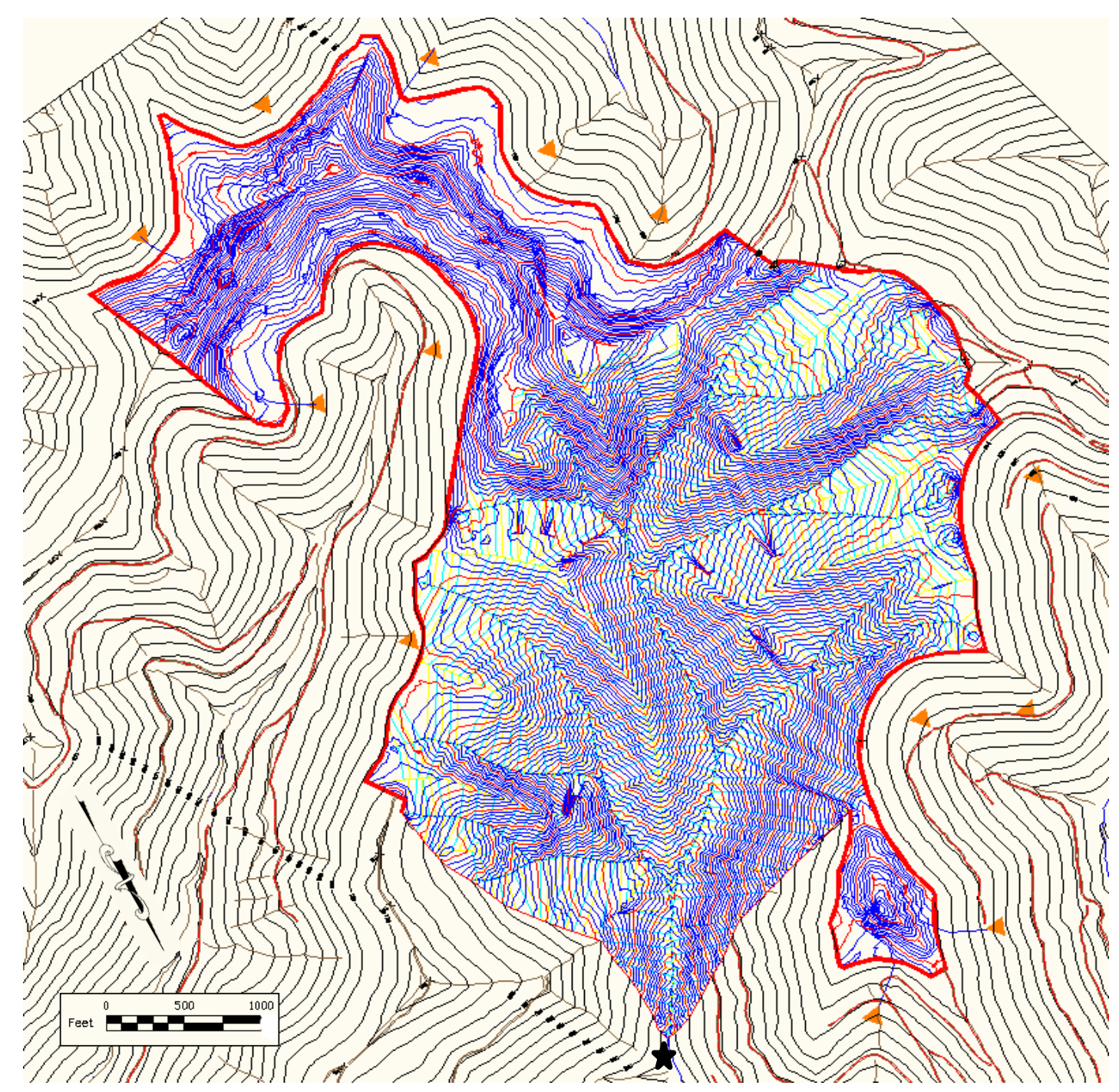

Figure 4.3.1: Contoured Edited GeoFluv ${ }^{T M}$ Surface Created at Sample Site 


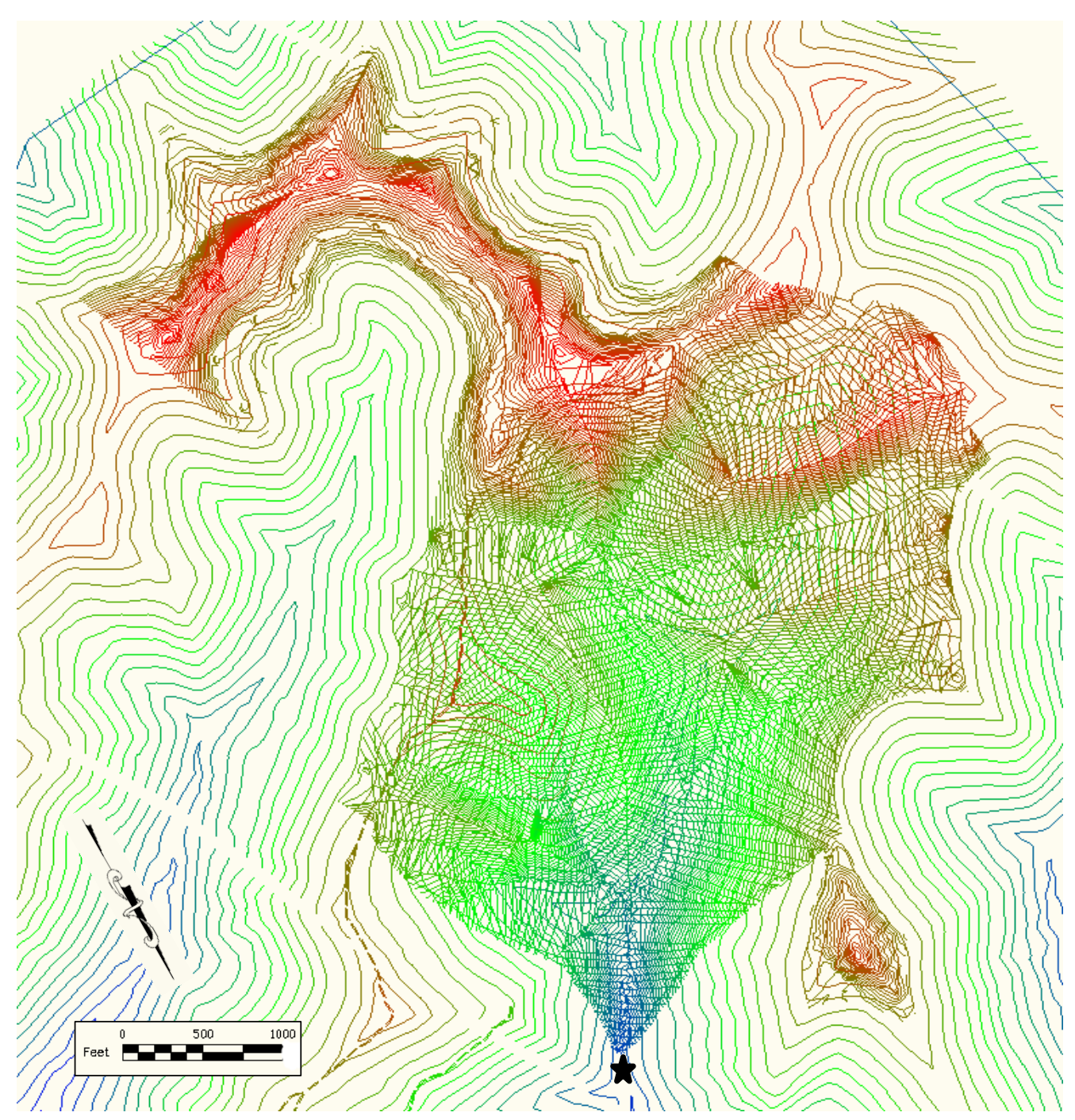

\section{Figure 4.3.2: Colored Contoured Edited GeoFluv ${ }^{T M}$ Surface Created at Sample Site}

Features of the completed geomorphic landform valley-fill design include a natural, aesthetically pleasing appearance that includes ridges, valleys, and stream channels that are mature landforms that will have little to no future erosion. These stable landforms reduce the long-term maintenance of the valley fill as well as mimic the function of the natural landscape that would have naturally evolved over time. The created stream channels control drainage and create stable hydrologic equilibrium over the valley fill. Figures 4.3 .3 to 4.3 .5 illustrate 3dimensional views of the completed geomorphic landform valley-fill designs that demonstrate all of the features described above. 


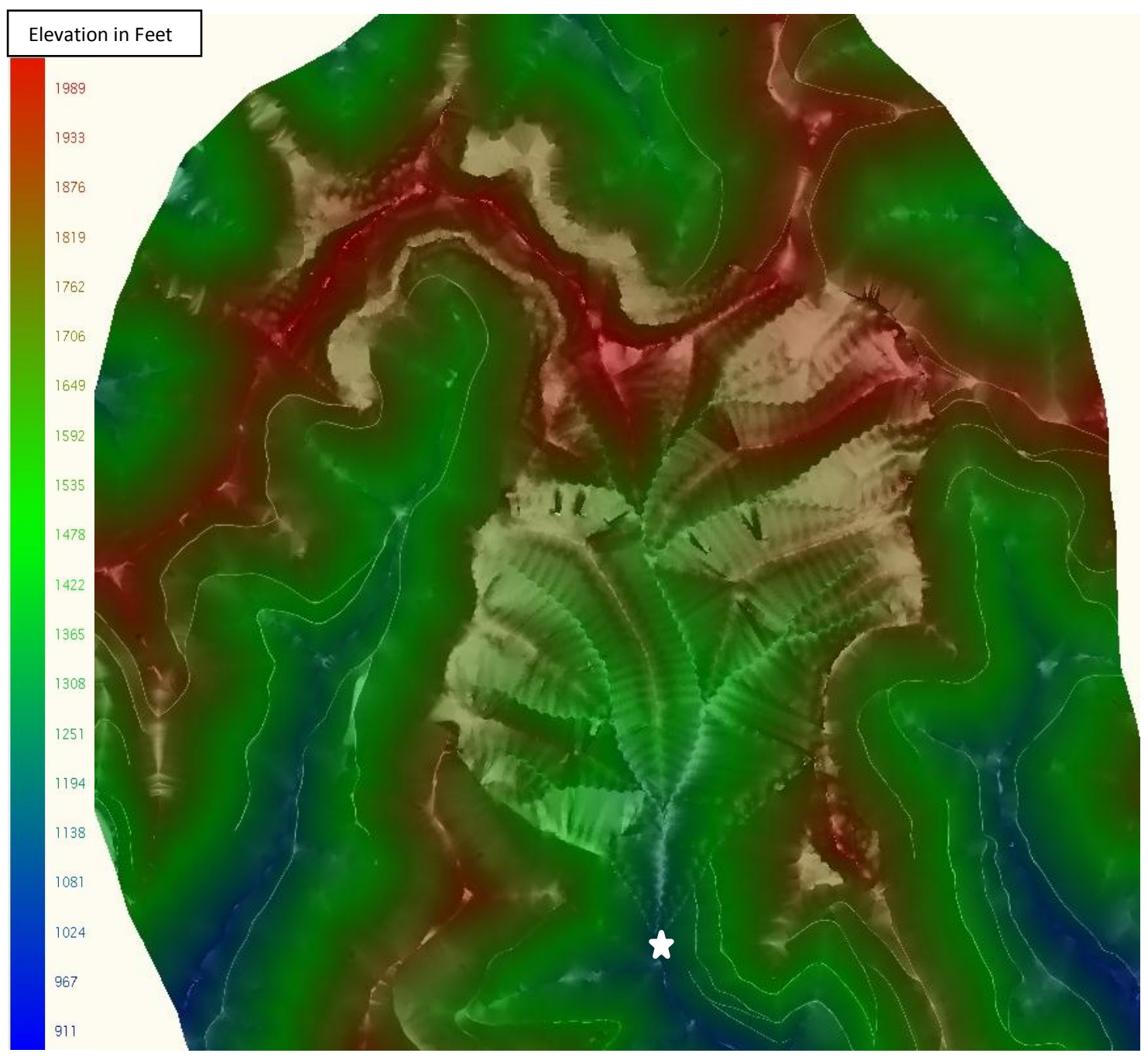

Figure 4.3.3: Completed 3-Dimensional Geomorphic Landform Valley-fill Design 


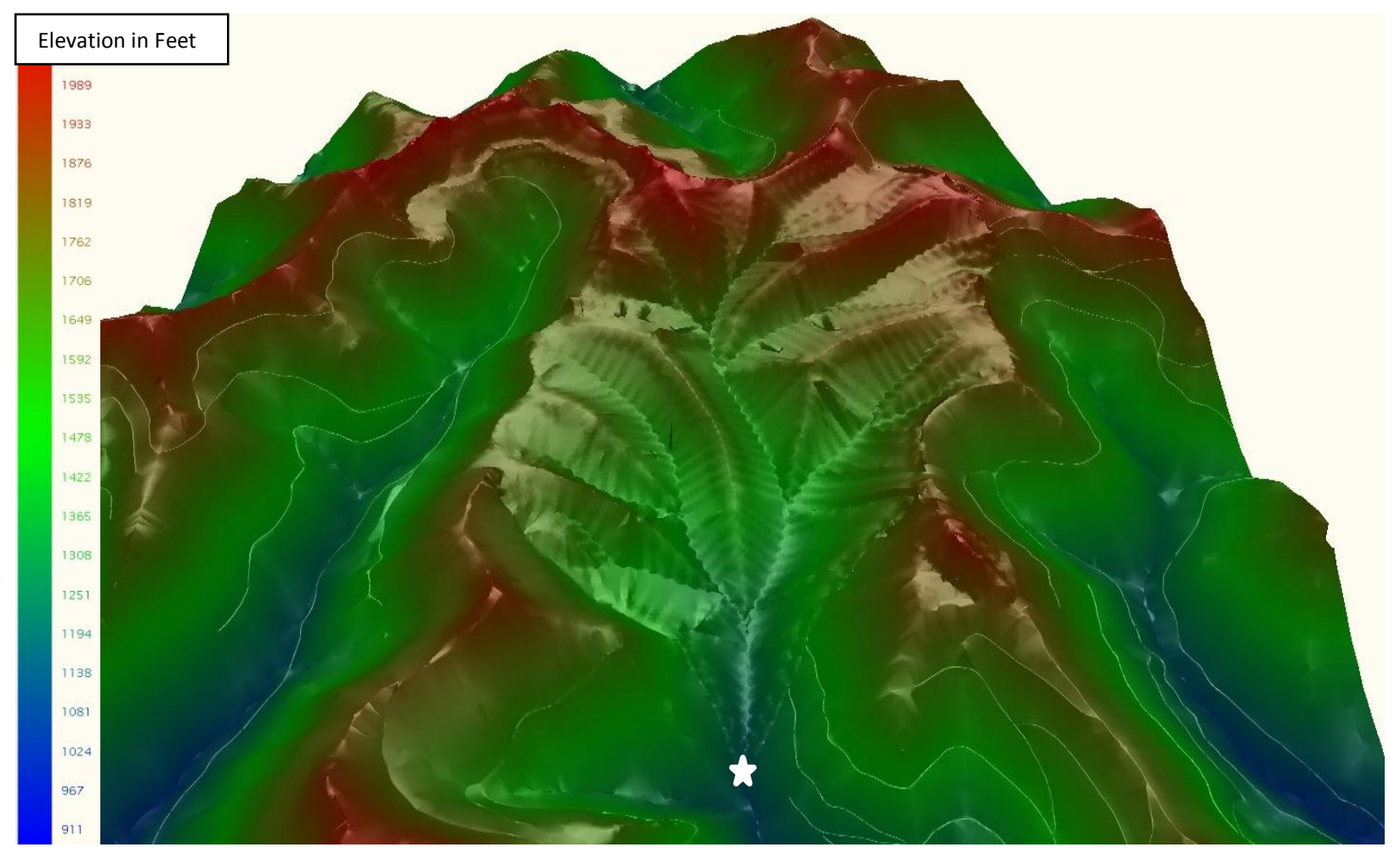

Figure 4.3.4: Completed Projected 3-Dimensional Geomorphic Landform Valley-fill Design

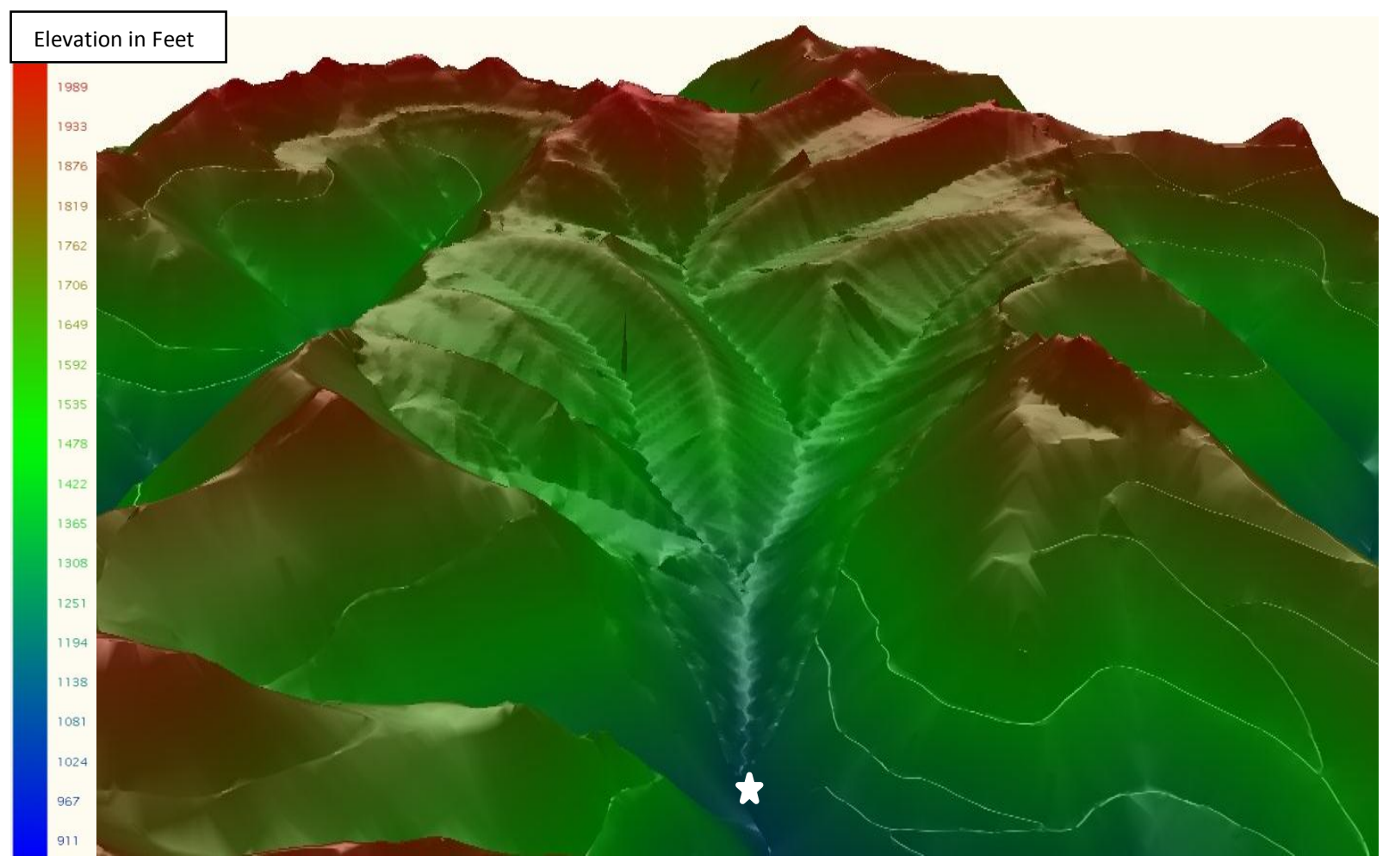

Figure 4.3.5: Completed Rotated 3-Dimensional Geomorphic Landform Valley-fill Design 


\subsection{Safety}

Another focus for this project was the safety of the miners and workers. The geomorphic landform valley-fill design of the sample site optimizes heavy equipment utilization in order to minimize worker exposure to potentially dangerous slope profiles, creates safer and more stable land profiles, and minimizes groundwater infiltration into underground mine working thus reducing mine inundation possibilities.

Fluvial geomorphic landform design has the potential to decrease operator exposure time in dangerous conditions by minimizes the amount of earthwork that has to be performed. In traditional reclamation practices, the soil has to be moved once during the mining process and again during reclamation. In the geomorphic landform design of the sample site, the soil that is removed during mining is transported directly to a location that was previously mined and is used to create valley fill landforms. Thus it cuts down on total distance traveled and the number of hours needed to complete the reclamation process making the geomorphic landform design safer for site workers. 


\section{AOC Variance vs. Geomorphic Design Comparison}

\subsection{Drainage Systems}

Surface water runoff control was incredibly important in any valley-fill design. For the traditional valley fill, runoff was directed away from the benched face of the fill and into Surface Water Runoff analysis (SWROA) ditches. However, there were also groin ditches that were located on each side of the valley fill face in case of excess precipitation events. Figure 5.1.1 below illustrates the drainage system of an AOC valley fill.

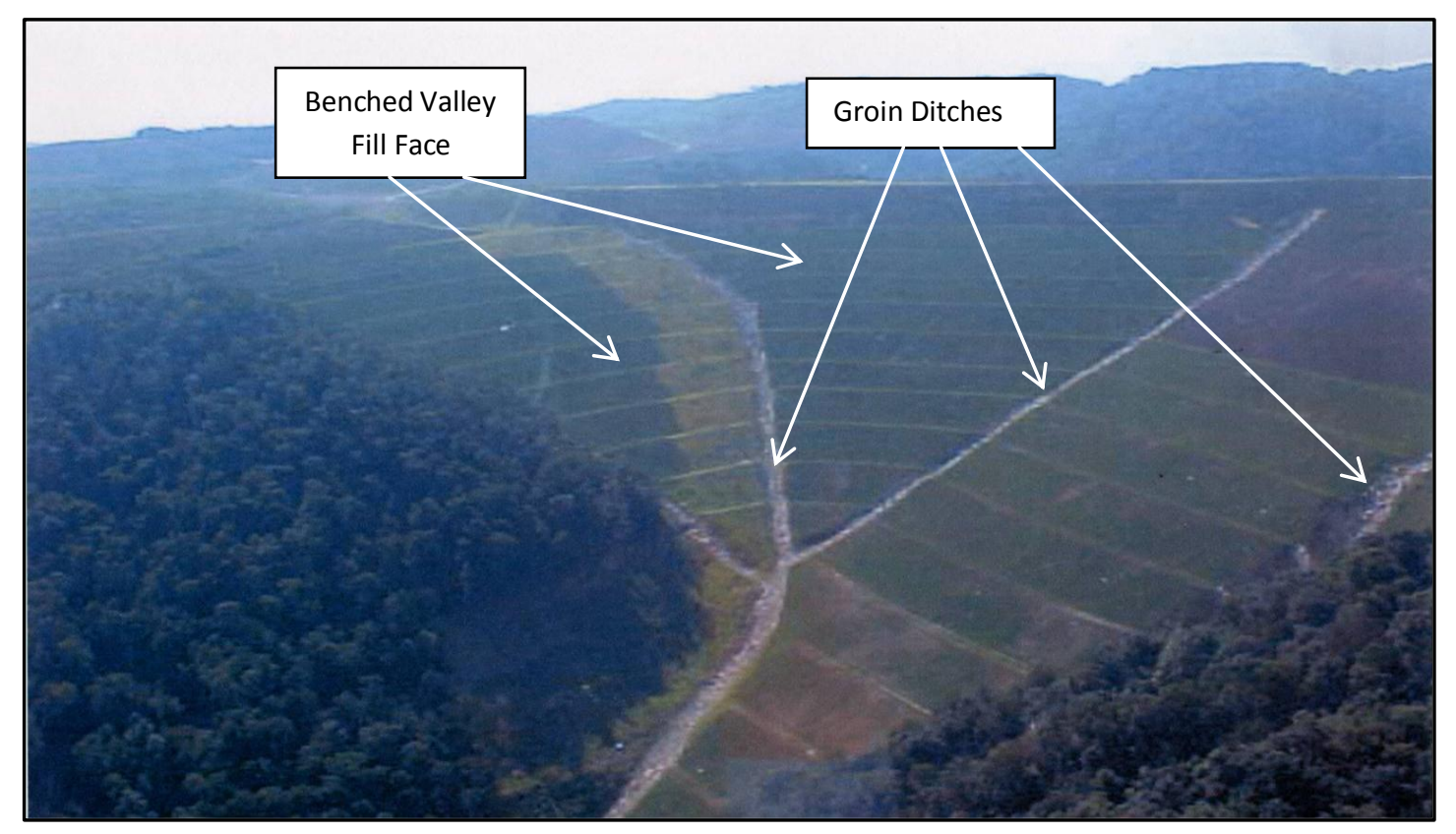

Figure 5.1.1: AOC Valley Fill Face with Labeled Drainage Structures

Drainage system design, by emulating natural processes, was thought of as a superior approach to landform design compared to conventional methods (Sawatsky and Beckstead, 1996). The geomorphic landform valley-fill design assisted in reducing surfical erosion and removed surface water more efficiently from the slope than traditional drainage methods. Conventional engineered drainage systems did not accommodate flooding because engineered 
streams typically were not mature landforms and therefore eroded until a hydrologic equilibrium was achieved. Fluvial geomorphic design used concepts which emulated natural processes and created mature landforms which minimized long-term erosion and flooding. This equilibrium was achieved through creating the proper drainage density in the watershed. Drainage density is a concept that attempts to quantify a natural and stable drainage system and is defined as the length of a channel divided by its contributing watershed area. Through geomorphic landform design principles, a targeted drainage density was achieved while replacing rip-rap drainage ditches with naturally vegetated sinusoidal channels (Sawatsky and Beckstead, 1996).

\subsection{Infiltration}

Infiltration was an important factor analyzed because it was ultimately linked to internal erosion and long-term stability of the structure. If infiltration could be minimized, internal erosion could be minimized and the long-term stability of the structure could be increased.

Given that adequate slope stability design had target density requirements for strength, loose end dumping construction methods typically resulted in landforms that became infiltrated with runoff and resulted in instability. Storm water runoff affects landforms created using end dumping techniques differently than it had before mining had occurred, even if the land was reclaimed to approximate original contour (Martin-Duque et al., 2010). In the past, infiltration and landslides were a common result of end dumping methods in landform construction (Bell et al., 1989).

Geomorphic landform design methods could minimize infiltration by reducing the amount of time surface water runoff is in contact with the surface of the valley fill. The decrease in infiltration could increase the long-term stability of the structure by reducing internal 
erosion. Fluvial geomorphic design provides precipitation with quick and easy routes into channels. Therefore, if the runoff contact time was minimized, the time the water had to collect contaminants that were within the fill would be reduced. Decreased infiltration results in slowed seepage rates and lower loading rates of contaminants into streams (Deissmann and Goldsworthy, 2003). Acid mine drainage and leaching of selenium into groundwater and streams are concerns that have received recent emphasis in the mining industry and are proposed to be reduced using geomorphic landform reclamation methods.

\subsection{Slope Stability}

Slope stability analysis should not be overlooked in surface mine reclamation because slope failure can have significant ecological impacts (Kenney and Lau, 1985). Geomorphic landform designs created using GeoFluv ${ }^{\mathrm{TM}}$ principles do not analyze the stability of the slopes. It is important that slope structures remain durable and do not fail when constructed with surface mine overburden for several reasons. If toxic mineralogy exists within the overburden, slope stability becomes an especially critical analysis that should be performed during the design planning process. It is also incredibly important to perform slope stability analysis to ensure the durability of the structure in Appalachia due to its steep terrain. Therefore, all created landforms, whether created using conventional AOC or geomorphic principles, should be analyzed properly in order to limit the steepness of slopes and insure the stability of the landforms because slope failures can have a significant impact on the health and safety of downstream communities as well as the operators constructing the structures. 


\section{Summary, Conclusions, and Areas of Future Research}

\subsection{Summary}

State and Federal regulations directing mine reclamation using the AOC approach have resulted in geotechnically stable designs of valley fills constructed using waste rock overburden. Environmental concerns at mountaintop mining sites abound because of the loss of headwater stream length and increased flooding risk. One promising technique to lessen the impacts involves fluvial geomorphic landform design applied to the waste rock fill and slope profiles. These innovative geomorphic landforms designs are often created using Carlson ${ }^{\circledR}$, s Natural Regrade $^{\circledR}$ with GeoFluv ${ }^{\mathrm{TM}}$ software.

The objective was to investigate geomorphic design reclamation approaches applied to surface mining methods in West Virginia. First, components of geomorphic landform design and associated regulations were collected, noting challenges associated with the application of the technique in West Virginia. Then, a conceptual geomorphic landform design of a mountaintop removal reclamation site was created using geomorphic landform design principles and methodologies. Finally, an analysis of the created valley-fill design with respect to stream

length, watershed area, and drainage density was completed in order to compare and contrast the data to a traditional valley-fill design.

The design tool Natural Regrade ${ }^{\circledR}$ with GeoFluv ${ }^{\mathrm{TM}}$ was used to apply the geomorphic landform design principles to the sample surface mine site that is located in the southern West Virginia coalfield region. The area was characterized by a system of steep-sloped ridges and valleys. A boundary line was drawn along the perimeter of the property; then the valley fill was divided into subwatersheds in order to create a natural appearance and balanced design. A majority of the default settings in Natural Regrade ${ }^{\circledR}$ were used in order to create the geomorphic 
landform design for the sample site due to the lack of on-site data because of current mining. However, two of the global settings that were drastically changed for the sample site were that the $2 \mathrm{yr}, 1 \mathrm{hr}$ rainfall changed from $0.6 \mathrm{in}$. to $1.41 \mathrm{in}$. and the $50 \mathrm{yr}, 6 \mathrm{hr}$ rainfall changed from 2.0 in. to 4.03 in. The default rainfall values are based on semi-arid regions of the United States where precipitation is lower as opposed to the higher precipitation region of the United States in which the sample site is located, based on type II storm and precipitation data.

Stream channels were created within each subwatershed boundary and geomorphic landform design principles were then applied to each subwatershed. Once all of the subwatershed designs were created using Natural Regrade ${ }^{\circledR}$ with GeoFluv ${ }^{\mathrm{TM}}$ they were combined so that the valley-fill design was complete. All of the data for each analyzed subwatershed was compiled so that a proper analysis of the total design was completed.

\subsection{Conclusions}

The geomorphic valley-fill design allowed $1300 \mathrm{ft}$ of original stream length to remain undisturbed compared to the traditional valley-fill design and almost 33,000 ft or 6.25 miles of stream length (type A and type C channels as defined by Rosgen) was created on the property (Table 1). In four of the six subwatersheds, only one channel was needed to satisfy the drainage density requirement due to the watershed area and the length the main channel. Even though only one channel was created, the valley fill created using Natural Regrade still had a greater amount of stream length within the same area compared to the original stream length (Table 6.0.1). 
Table 6.0.1: Geomorphic Landform Design Data of Sample Site

\begin{tabular}{|c|c|c|c|c|c|c|c|}
\hline & \multicolumn{6}{|c|}{ Subwatershed } & \multirow{2}{*}{$\begin{array}{c}\text { Total } \\
\text { Watershed }\end{array}$} \\
\hline & 1 & 2 & 3 & 4 & 5 & 6 & \\
\hline Area (ac) & 241 & 32 & 36 & 21 & 4 & 6 & 340 \\
\hline Elevation range of topography $(\mathrm{ft})$ & $\begin{array}{c}1150- \\
1995\end{array}$ & $\begin{array}{l}1720- \\
1995\end{array}$ & $\begin{array}{l}1650- \\
1995\end{array}$ & $\begin{array}{l}1720- \\
1993\end{array}$ & $\begin{array}{c}1780- \\
1897\end{array}$ & $\begin{array}{c}1720- \\
1900\end{array}$ & $\begin{array}{l}1150- \\
1995\end{array}$ \\
\hline Original stream length (ft) & 8630 & 1180 & $\mathrm{NA}^{*}$ & 460 & NA & NA & 10270 \\
\hline Number of created channels & 13 & 1 & 1 & 2 & 1 & 1 & 19 \\
\hline Range of created stream length (ft) & $\begin{array}{l}814- \\
5290\end{array}$ & 3159 & 3551 & $\begin{array}{l}580- \\
1505\end{array}$ & 487 & 510 & $\begin{array}{l}487- \\
5290\end{array}$ \\
\hline Total created stream length & 21902 & 3159 & 3551 & 2085 & 487 & 510 & 31694 \\
\hline Original stream length saved (ft) & 1315 & NA & NA & NA & NA & NA & 1315 \\
\hline Drainage density $(\mathrm{ft} / \mathrm{ac})^{\dagger}$ & 90.62 & 99.35 & 98.76 & 98.42 & 116.78 & 90.09 & \\
\hline Rosgen Channel type & $\mathrm{A}, \mathrm{C}$ & $\mathrm{A}, \mathrm{C}$ & $\mathrm{A}, \mathrm{C}$ & $\mathrm{A}, \mathrm{C}$ & $\mathrm{A}, \mathrm{C}$ & $\mathrm{A}, \mathrm{C}$ & $\mathrm{A}, \mathrm{C}$ \\
\hline
\end{tabular}

$\uparrow$ Target drainage density range: $80-120 \mathrm{ft} / \mathrm{ac}$

$\ddagger \mathrm{NA}=$ not applicable.

An AOC Variance valley-fill design was being implemented at the sample site in southern West Virginia. The post-mined land use of the area was determined to be pasture land and therefore an AOC variance was obtained in order to leave the land relatively flat at an elevation of approximately $1700 \mathrm{ft}$. The main feature of the AOC variance valley fill was a benched valley fill face. Runoff from the property drained to SWROA ditches that outlined the boundary and out NPDES points into surrounding stream channels. Table 6.0.2 shows that the design filled in almost 21,000 feet of original stream channel length and in return created no stream channels.

Table 6.0.2: AOC Variance Design Data of Sample Site

\begin{tabular}{lc}
\hline & $\begin{array}{c}\text { Watershed } \\
\text { AOC Variance }\end{array}$ \\
\hline Area (ac) & 339.9 \\
Elevation range of topography & 1693 \\
Original stream length (ft) & 10,270 \\
Number of created channels & $\mathrm{NA}^{\ddagger}$ \\
Range of created stream length (ft) & NA \\
Total created stream length & NA \\
Original stream length saved (ft) & NA \\
Drainage density (ft/ac) & NA \\
Rosgen Channel type & NA \\
\$NA = not applicable. &
\end{tabular}


The data collected from the AOC variance valley-fill design and the geomorphic landform valley-fill design created using Natural Regrade ${ }^{\circledR}$ with GeoFluv ${ }^{\mathrm{TM}}$ were compared.

The AOC variance valley-fill design was intended to ensure slope stability, control drainage, complement the drainage pattern of the surrounding terrain, and prevent stream sedimentation. The design consisted of:

- slope shapes exhibiting uniform benches

- planar slopes having unvarying contours

- drainage ditches located along the perimeter and/or center of the fill

However, the traditional, planar reclamation method can be improved to appear more natural and decrease the drawbacks associated with it.

Features of the resulting Natural Regrade ${ }^{\circledR}$ design include:

- long-term stability due to dynamic equilibrium

- $\quad$ suggested reduction in maintenance due to stability

- $\quad$ projected reduced cost due to strategic placement of fill material

- more aesthetically pleasing valley fill due to a diverse natural habitat with ridges and valleys

These landform designs add variability and aid in establishing a site with a long-term hydrologic balance. The geomorphic landform reclamation approach has potential to extend beyond current industry practices and will improve environmental impacts, flood control, water quality, and human safety. 


\subsection{Areas of Future Research}

The outcome of this study identified several areas for future research. The first area addressed existing valley fill structures which may benefit from implementing the geomorphic methods, specifically by re-contouring the surface drainage structures in order to create streams where slope gradients are suitable. A second area was to study several existing valley fills to identify surface water runoff rates and volumes in order to perform re-grading to create perennial stream channels. As of this writing, the researchers have been awarded support, by the U.S. Department of Interior's Office of Surface Mining, Reclamation, and Enforcement, and by the U.S. Geologic Survey, to further geomorphic studies in Appalachia. 


\section{References}

Bell J.C., Daniels W.L., Zipper C.E., 1989. "The Practice of “Approximate Original Contour” in the Central Appalachians. I. Slope Stability and Erosion Potential." Landscape and Urban Planning, Vol. 18, pp. 127-138.

Bhatt S.K., Mark C., "Analysis of Safety Aspects and Mining Practices for Effective Ground Control in Surface Mining." National Institute for Occupational Safety and Health. Pittsburgh Research Laboratory. Pittsburgh, Pennsylvania.

Bugosh N., 2004. "Computerizing the fluvial geomorphic approach to land reclamation." National Meeting of the American Society of Mining and Reclamation and The 25th West Virginia Surface Mine Drainage Task Force, April 18-24, pp. 240-258.

Bugosh N., 2009. "A summary of some land surface and water quality monitoring results for constructed GeoFluv landforms." Revitalizing the Environment: Proven Solutions and Innovative Approaches, National Meeting of the American Society of Mining and Reclamation, Billings, MT, May 30-June 5, pp.153-175.

Carlson ${ }^{\circledR}$, 2011. "Carlson ${ }^{\circledR}$ Natural Regrade ${ }^{\circledR}$." Carlson ${ }^{\circledR}$ : Software for Land Development Professionals.

Caterpillar Performance Handbook: Edition 37. Peoria, Illinois Caterpillar, Inc., February 2007

Cecala A.B., Organiscak J.A., Heitbrink W.A., Zimmer J.A., Fisher T., Gresh R.E., and Ashley II J.D., 2004. "Reducing Enclosed Cab Drill Operator's Respirable Dust Exposure at Surface Coal Operations with a Retrofitted Filtration and Pressurization System.” SME Transactions 2003, Vol. 314, Littleton, CO: Society for Mining, Metallurgy and Exploration, Inc., pp. 31-36.

Collins J.L., Fytas K., Singhal Raj K., 1986. "Design, construction and maintenance of surface mine haulage roads." International Symposium on Geotechnical Stability in Surface Mining. 1986, pp. 39-49. 
Davis E.D., Duffy R.J., 2009. “King coal vs. reclamation: Federal regulation of mountaintop removal mining in Appalachia." Administration and Society, Vol. 41(6), pp. 674-692.

Deissmann G., Goldsworthy M. et al., 2003. "Design constraints on engineered dry covers for waste rock dumps.” Brenk Systemplanung, Aachen, Germany.

Eckels R., Bugosh N., 2010. "Natural approach to mined land reclamation.” FIG Congress 2010.

Ferrari J.R., Lookingbill T.R., McCormick B., Townsend P.A., 2009. “Surface mining and reclamation effects on flood response of watersheds in the central Appalachian Plateau region." Water Resources Research, 45, W04407.

Groininger J., Skousen J., Angel P., Barton C., Burger J., Zipper C., 2007, “Mine reclamation practices to enhance forest development through natural succession," The Appalachian Regional Reforestation Initiative (ARRI) Rorest Reclamation Advisory, July, 2007.Rosgen D., 1996, “Applied river morphology,” Wildland Hydrology, Pagosa Springs, CO.

Groves W.A., Kecojevic V.J., Komljenovic D. “Analysis of fatalities and injuries involving mining equipment.” Journal of Safety Research Vol. 38, pp. 461-470.

Hartman K.J., Kaller M.D., Howell J.W., Sweka J.A., 2005. "How much do valley-fills influence headwater streams?" Hydrobiologia, Vol. 532, pp. 91-102.

Hasselman, M., 2002. "Bragg v. W-Va. Coal Association and the unfortunate limitation of citizen suits against the state in cooperative federalism regimes." Ecol. Law Quart., Vol. 29, pp. 205-229.

Hause D., "Successful reclamation of the Log Creek Church site." Technical Innovation and Professional Services.

Kenney T.C., Lau D., 1985. "Internal stability of granular filters.” Canadian Geotechnical Journal, Vol. 22, pp. 215-225. 
Kissell F.N., "Handbook for Dust Control in Mining." Washington D.C.: U.S. Dept. of Human Health Services; 2003. Publication No. 2003-147.

Lindsey R. Simmon R., 2007. “Coal controversy in Appalachia.” NASA Earth Observatory, 2007.

Martin-Duque J.F., Sanz M.A., Bodoque J.M., Lucia A., Martin-Moreno C., 2009. "Restoring earth surface processes through landform design. A 13-year monitoring of a geomorphic reclamation model for quarries on slopes." Earth Surface Processes and Landforms, Vol. 35 , pp. 531-548.

Martin-Moreno C., Martin-Duque J.F., Nicolau J.M., Sanchez L., Ruiz R., Sanz M.A., Lucia A,, Zapico I., 2008. "A geomorphic approach for the ecological restoration of kaolin mines at the Upper Tagus Natural Park (Spain)." $6^{\text {th }}$ European Conference on Ecological Restoration, Ghent, Belgium, August 8-12, 2008.

McQuaid J., 2009. "Mountaintop mining legacy: destroying Appalachian streams.” Yale Environment 360, July 20, 2009.

Measles D., Bugosh N., 2007. "Making and building a fluvial geomorphic reclamation design at an active dragline mine using the GeoFluv ${ }^{\mathrm{TM}}$ design method." 30 Years of SMCRA and Beyond, National Meeting of the American Society of Mining and Reclamation, Gillette, WY, June 2-7, pp. 449-456.

Michael P.R., Superfesky M.J., Uranowski L.J., 2010. “Challenges to applying the geomorphic and stream reclamation methodologies to mountaintop mining and excess spoil fill construction in steep-slope topography (e.g. Central Appalachia).” 2010 National Meeting of the American Society of Mining and Reclamation, Lexington, KY, June 5-11, pp. 610-634.

Pond G.J., Passmore M.E., Borsuk F.A., Reynolds L., Rose C.J., 2008. "Downstream effects of mountaintop coal mining: comparing biological conditions using family- and genus-level macroinvertebrate bioassessment tools." J. N. Am. Benthol. Soc., Vol. 27(3), pp. 717737. 
Robson M., Spotts R., Wade R., Erickson W., 2009. “A case history: Limestone quarry reclamation using fluvial geomorphic design techniques." Revitalizing the Environment: Proven Solutions and Innovative Approaches, National Meeting of the American Society of Mining and Reclamation, Billings, MT, May 30-June 5, pp. 1166-1175.

Rosgen D.L., 1994. “A classification of natural rivers.” Catena, Vol. 22, pp. 169-199.

Rosgen D.L.1996. Applied River Morphology. Wildland Hydrology, Pagosa Springs, Colorado.

Ruff T., 2004. "Advances in proximity detection technologies for surface mining equipment. Proc. Of $34^{\text {th }}$ AIMHSP, Salt Lake City, 2004.

Ruff, T., 2007. "Recommendations for evaluating and implmenting proximity warning systems on surface mining equipment.” NIOSH Report of Investigations 9672, June 2007

Sawatsky L., Beckstead G., 1996. "Geomorphic approach for design of sustainable drainage systems for mineland reclamation.” International Journal of Mining, Reclamation and Environment, Vol. 10(3), pp. 127-129.

Schiffbauer W.H., 2001. "An active proximity warning system for surface and underground mining applications, Pittsburg, PA: National Institute for Occupational Safety and Health, NIOSHTIC-2 No. 20021434, 2001.

Schor H.J., Gray D.H., 1995. "Landform grading and slope evolution.” Journal of Geotechnical Engineering, Vol. 121(10), pp. 728-734.

Skousen J.G., Venable C.L., 2008, "Establishing native plants on newly-constructed and olderreclaimed sites along West Virginia Highways," Land Degradation \& Development, 2007.

Superfesky, M., Michael P., 2007. "Excess spoil minimization and fill stability." Proc., SME Annual Meeting, SME, Denver, CO, pp. 1-13.

Toy T.J., Chuse W.R., 2005. “Topographic reconstruction: a geomorphic approach.” Ecological Engineering, Vol. 24, pp. 29-35. 
U.S. Department of Labor: Mine Safety and Health Administration, 2009. Report of Investigation: Surface Coal Mine Fatal Machinery Accident (ID No. 15-18955). Pikeville, KY.

U.S. Department of Labor: Mine Safety and Health Administration, 2011. Report of Investigation: Surface Coal Mine Fatal Machinery Accident (ID No. 15-17821). Barbourville, KY.

USEPA, 2005. Final Programmatic Environmental Impact Statement (PEIS) on Mountaintop Mining/Valley-fills in Appalachia (EPA 9-03-R-05002). U.S. Environmental Protection Agency.

West Virginia Office of Miners' Health Safety and Training, 2011. "West Virginia mining statistics 1996-2010: 2011 West Virginia Statistical Data.” 